Florida International University FIU Digital Commons

\title{
Technology professional development for principals : impact on the integration of technology in elementary schools
}

Tarek Chebbi

Florida International University

DOI: $10.25148 /$ etd.FI14060154

Follow this and additional works at: https:// digitalcommons.fiu.edu/etd

Part of the Curriculum and Instruction Commons

\section{Recommended Citation}

Chebbi, Tarek, "Technology professional development for principals : impact on the integration of technology in elementary schools" (2005). FIU Electronic Theses and Dissertations. 2122.

https://digitalcommons.fiu.edu/etd/2122 


\section{FLORIDA INTERNATIONAL UNIVERSITY}

Miami, Florida

TECHNOLOGY PROFESSIONAL DEVELOPMENT FOR PRINCIPALS: IMPACT ON THE INTEGRATION OF TECHNOLOGY IN ELEMENTARY SCHOOLS

A dissertation submitted in partial fulfillment of the

requirements for the degree of

DOCTOR OF EDUCATION

in

CURRICULUM AND INSTRUCTION

by

Tarek Chebbi

2005 
To: Dean Linda Blanton

College of Education

This dissertation, written by Tarek Chebbi, and entitled Technology Professional Development for Principals: Impact on the Integration of Technology in Elementary Schools, having been approved in respect to style and intellectual content, is referred to you for judgment.

We have read this dissertation and recommend that it be approved.

Kingsley Banya

Mohammed K. Farouk

Zhonghong Jiang, Co-Major Professor

Abbas Tashakkori, Co-Major Professor

Date of Defense: July 29, 2005

The dissertation of Tarek Chebbi is approved.

Dean Linda Blanton

College of Education

Dean Douglas Wartzok

University Graduate School

Florida International University, 2005 
(C) Copyright 2005 by Tarek Chebbi

All rights reserved. 


\section{DEDICATION}

This dissertation is dedicated to my father, Abdallah Ben Massaoud, who kept asking me when I would get my doctorate and kept reminding me of the prophet (P.B.U.H) saying "Seek knowledge from the cradle to the grave". I also dedicate this dissertation to my wife Esther for her continued support and for my children Yasmin Nour, Anyssa Habiba, Aisha Fatima, and Khalil Abdallah for their sacrifices and encouragement despite their young ages. Finally, I want to dedicate this dissertation to the memory of mother Habiba (May Allah bless her soul and accepts her in his paradise). 


\section{ACKNOWLEDGMENTS}

It is with deep appreciation and sincere thanks that I acknowledge the many people who assisted me in this educational journey. I am deeply indebted to the Chair of my Dissertation Committee, Dr. Abbas Tashakkori, for his continuous support, encouragement, and the many hours he spent with me working on this dissertation: On campus, off campus, and even during his vacation.

I am very grateful to my Co-Major Professor, Dr. Zhonghong Jiang for his assistance and help, especially during the course-work period. I am also extremely grateful to my two committee members: Dr. Kingsley Banya and Dr. Mohammed Farouk for their continuous mentoring, assistance, and friendship for over five years.

Special thanks to some FIU faculty members that have supported me directly or indirectly, specifically, Dean Linda Blanton, Dr. Gail Gregg, Dr. Leonard Bliss, and Dr. Frank Di Vesta for their continuous encouragement and assistance. 


\section{ABSTRACT OF THE DISSERTATION \\ TECHNOLOGY PROFESSIONAL DEVELOPMENT FOR PRINCIPALS: IMPACT ON THE INTEGRATION OF TECHNOLOGY IN ELEMENTARY SCHOOLS}

by

Tarek Chebbi

Florida International University, 2005

Miami, Florida

Professor Abbas Tashakkori, Co-Major Professor

Professor Zhonghong Jiang, Co-Major Professor

The use of technology in schools is no longer the topic of educational debates, but how to ensure that technology is used effectively continues to be the focal point of discussions. The role of the principal in facilitating the successful integration of technology in the school is well established. To that end, the Florida Department of Education implemented the FloridaLeaders.net: a three-year professional development project in technology for school administrators. The purpose of this study was to investigate the effectiveness of this professional development project on integrating technology in elementary schools.

The study compared a group of schools whose principals have participated in the FloridaLeaders.net (FLN) program with schools whose principals have not participated in the program. The National Technology Standards for School Administrators and the National Technology Standards for Teachers were used as the framework to assess technology integration. 
The sample consisted of three groups of educators: principals $(n=47)$, media specialists $(n=110)$, and teachers $(n=167)$. Three areas of technology utilization were investigated: a) the use of technology in management and operations, b) the use of technology in teaching and learning, and c) the use of technology for assessment and evaluation. Analyses of variances were used to examine the differences in the perceptions and use of technology in each of the three areas, among the three groups of educators.

The findings indicated that the difference between FLN and non-FLN schools was not statistically significant in most of the technology indicators. The difference was however significant in two cases: a) The use of technology for assessment and evaluation, and b) The level of technology infrastructure in FLN schools. Additionally, all FLN and non-FLN groups reported the need for technology training for teachers to provide them with the necessary "know-how" to effectively integrate technology into the classrooms.

These findings would indicate that FloridaLeaders.net was not effective in integrating technology in schools over and above other current efforts. It is therefore concluded that the FLN project had some favorable impact but had not met all of its stated objectives. 


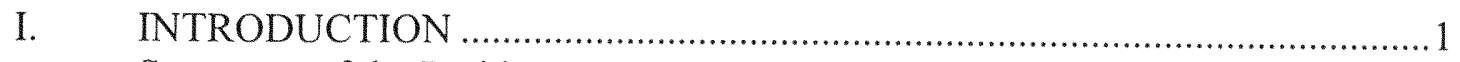

Statement of the Problem ........................................................................... 7

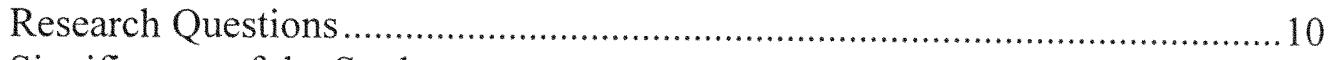

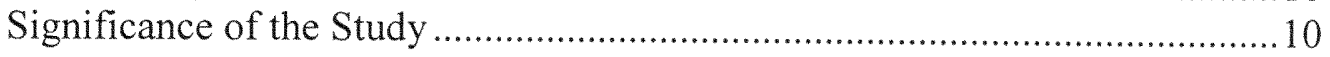

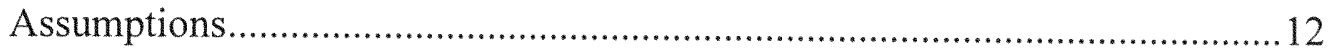

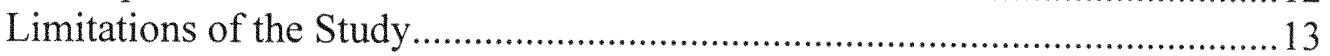

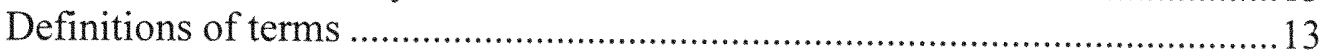

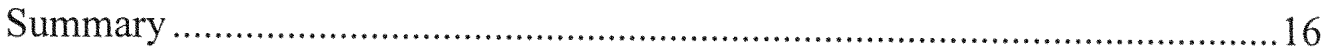

II. REVIEW OF THE LITERATURE …….................................................. 17

Current Applications of Technology ......................................................... 18

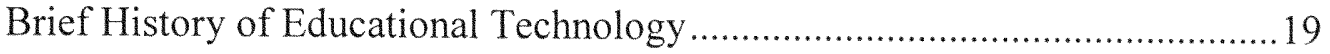

Current Status of Educational Technology ..................................................21

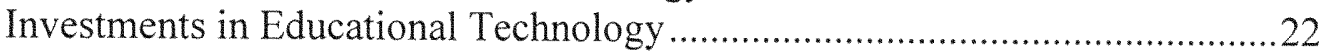

Challenges and Opportunities in Educational Technology .............................24

The Human Capital in Educational Technology ..............................................25

The Role of the Principal in Educational Technology ....................................27

Professional Development in General ...........................................................32

Elements of a Quality Professional Development in Technology ....................33

Evaluation of Impact of Professional Development ..........................................46

Conceptual Framework for the Study ......................................................51

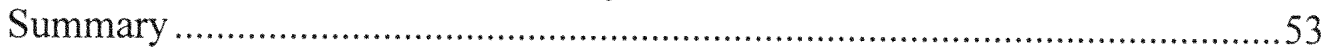

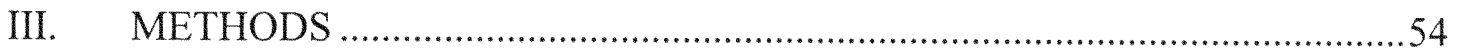

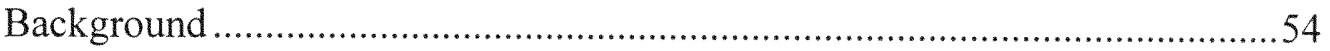

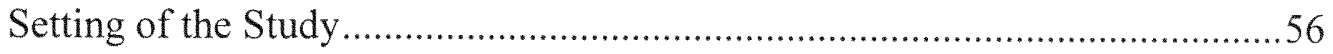

Selection of the Participants and Description of the Samples .........................57

Instrumentation and Description of the Questionnaires..................................61

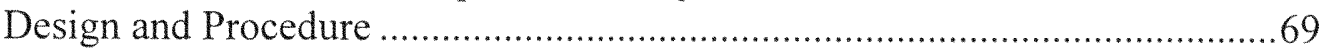

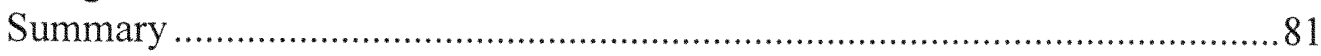

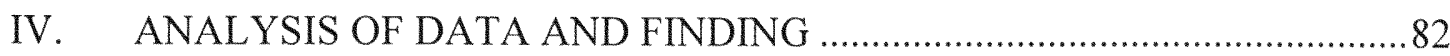

Discussion of the Subsidiary Research Questions ...........................................83

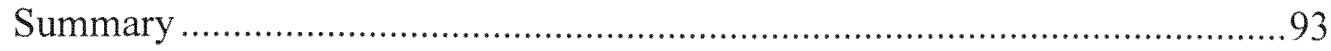

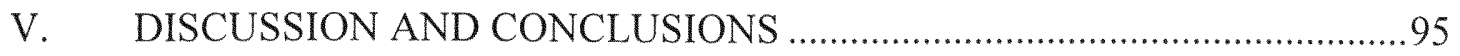

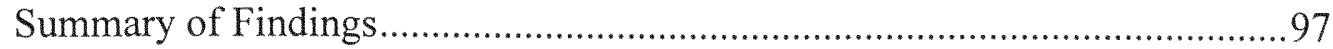

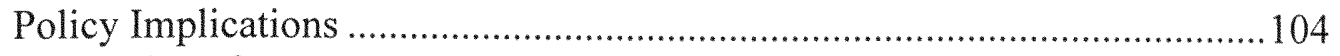

Suggestions for Future Research ............................................................. 106 


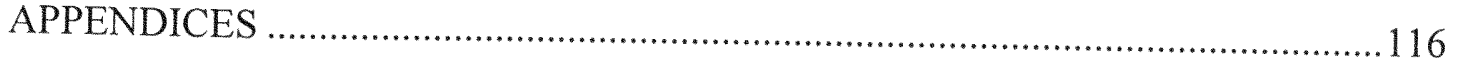

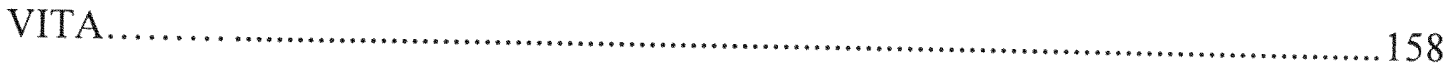


3.1 Demographic Comparison between the Sample and the Population of Elementary School Principals....

3.2 Demographic Comparison between the Sample and the Population of Elementary Schools: Media Specialists' Respondents.

3.3 Demographic Comparison between the Sample and Population of Elementary Schools: Teachers' Respondents

3.4 Number of Items Measuring Each Area of Technology Use in Each of the Three Questionnaires: the Principal, the Teachers, and the Media Specialists

3.5 Factor Structure of the Technology Use for Management and Operations: Principals' Questionnaire.

3.6 Factor Structure of the Technology Use for Management and Operations: Teachers' Questionnaire.

3.7 Factor Structure of the Technology Use for Management and Operations: Media Specialists' Questionnaire

3.8 Factor Structure of Technology Use in Learning and Teaching: Principals' Questionnaire.

3.9 Factor Structure of Technology Use in Learning and Teaching: Teachers' Questionnaire.

3.10 Factor Structure of Technology Use in Learning and Teaching: Media Specialists' Questionnaire.

3.11 Factor Structure of Technology Use in Assessment and Evaluation: Principals' Questionnaire.

3.12 Factor Structure of Technology Use in Assessment and Evaluation: Teachers' Questionnaire

3.13 Factor Structure of Technology Use in Assessment and Evaluation: Media Specialists' Questionnaire. 
3.14 List of Subscales (technology dimensions) Measuring the TMO,

TLT, and TAE in Each of the Three Questionnaires:

Principals, Teachers, and Media Specialists

4.1 Use of Technology in Management and Operations:

Principals' Reports

4.2 Use of Technology in Management and Operations:

Teachers' Reports

4.3 Use of Technology in Management and Operations:

Media Specialists' Reports..................................... 86

4.4 Use of Technology in Learning and Teaching:

Principals' Reports.

4.5 Use of Technology in Learning and Teaching:

Teachers' Reports.

4.6 Use of Technology in Learning and Teaching:

Media Specialists' Reports.

4.7 ANOVA Results of the Use of Technology in Learning and

Teaching: Media Specialists' Reports.

4.8 Use of Technology in the Assessment and Evaluation:

Principals' Reports 


\section{CHAPTER I \\ INTRODUCTION}

The National Commission on Excellence in Education report: A Nation at Risk (1983) focused the attention of the country on the status of education in the United States, and concluded that students were not learning and that schools were in decline. The findings of the report generated a plethora of studies and research that showed that American students were lagging behind students from other countries (TIMSS report 1994, 1998, and 2000). This outcry resulted in diminishing confidence in American schools to prepare students for the 21 st century.

In response to this pressure for educational reform, State Departments of Education throughout the country developed curriculum standards to define expectations for students and to provide frameworks for curriculum alignment and school accountability. Most of these standards urged the use and integration of technology into the teaching and learning process. For example, as part of the No Child Left Behind Act (NCLB), the US Department of Education created the Enhancing Education Through Technology (EETT) program and has been funding it at an average of $\$ 600$ million a year for the past five years. The last US Senate appropriation for the EETT program was in the amount of $\$ 425$ million and was approved on July 12,2005 . The EETT goals are to provide states and districts with funding to purchase hardware and software, use at least $25 \%$ of the funds to provide technology professional development, and develop innovative technology programs. Despite these investments, the debate over how to effectively integrate technology in schools continues among scholars and stakeholders in the education field as well as within the business community. This debate is converging 
to the agreement that technology can play an important role in supporting teaching and learning if used properly. Today, technology is invading the classrooms with or without the consent of the teacher or the principal. Technology is changing rapidly, and is becoming increasingly adaptable to most subject matters. Gardner (2000) indicated clearly that a marriage between education and technology could be consummated. However, he also added, that it will only be a happy marriage if those in charge of education remain clear on what they want to achieve for the students and vigilant that the technology serves these ends.

Technology in education has become increasingly pliable to different situations, and, as technology progresses, instructional technology becomes a vital component in schools. Robert McClintock, a scholar from the Institute of Learning Technologies at Teachers College, Columbia, indicated that digital technologies in education are as essential to education as steel and reinforced concrete are essential to architecture.

At the post secondary education level, for example, Duke University distributed free Apple iPods to all of its 1,650 incoming freshman students in fall 2004. The objective of the Duke administration was to get the students to use the iPods as minicomputers that can record and download lectures, assignments, and other information from a new web site that the university created for this experiment. Furthermore, hi-tech multinationals such as Microsoft, IBM, Oracle, and Unisys Corporations are educating their own future workforce. Faced with a chronic shortage of qualified technology college graduates to recruit and hire as software engineers, these corporations created their own university near Salt Lake City, Utah. This for-profit institution Northface University, opened in 2003, was accredited by the Accrediting Council for Independent 
Colleges and Schools (ACICS), and offers students a 28-month Bachelor's degree in computer science, about half the normal time, for a cost of about $\$ 60,000$. The intent of this new type of higher education "destination school" is to quickly turn out industrytrained, ready-to-work software designers to address the growing demand from the technology-based industry (http://www.northface.edu, Retrieved December 23, 2004).

Educators such as William Bennett (former Secretary of Education in the Reagan's administration) have developed technology-based curriculum programs that use traditional curriculum. Bennett's model targets the K-12 level and it is based on E.D. Hirsh's Core Knowledge series. Originally skeptical of the role of technology in education, Bennett and his constituency have now accepted the use of online technology to convey their curriculum based on the classics.

Realizing the important role of technology in improving teaching and learning in American schools, policy makers, educators, and other stakeholders from public and private sectors are investing heavily in the use of technology in education. The use of technology in schools is no longer the topic of educational debate. The current emphasis is on ensuring that technology is used effectively to create new opportunities for teaching, learning, and to improve student achievement.

Unfortunately, despite the considerable investments in technology, schools have failed to join the information revolution. Bailey (2002) stated that education has not kept pace with other sectors in the use and the integration of technology, and that the principals' lack of vision and understanding of the potential of technology is the major obstacle to bringing schools into the information age. Principals, whose roles are to lead the faculty, staff, and set the agenda for the school, have not yet mastered or even 
understood how to best implement the pivotal role that technology is playing in the educational system of the $21^{\text {st }}$ century (Mac Neil \& Delafield, 1998).

The realization of the importance of the role of the principal in the successful implementation of technology in Florida schools, and the realization of the need for a quality professional development in technology for administrators, led the Florida Department of Education to develop a partnership with several educational agencies to take advantage of a leadership development challenge grant through the Bill and Melinda Gates Foundation. The Bill and Melinda Gates Foundation committed $\$ 350$ million in grants for State Educational Agencies, over a three-year period: 2000, 2001, and 2002, to fund leadership professional development for principals and superintendents throughout the United States (www.gatesfoundation.org/education/grants/programguidelines.htm).

The purpose of these grants was to enhance the skills of school leaders to enable them to effectively integrate technology into the classrooms and curricula of schools throughout the nation. Specifically, school administrators would be able to develop, practice and share strategies, skills and processes for leading systemic change. They would be able to locate and use resources that enable their teachers to integrate technology into the classrooms to improve teaching and learning. They would also address long-range planning issues that include adequate professional development experiences for teachers and build technology capacity in the infrastructure of school facilities.

The Florida Department of Education (FLDOE), in a partnership with the Florida Technology Trainer Enhancement Center, the six regional Area Centers for Educational Enhancement, the South Florida Annenberg Challenge, and the Florida Association of 
District School Superintendents raised the matching funds to secure a grant from the Bill and Melinda Gates Foundation to fund the FloridaLeaders.net project. The project amount was about $\$ 11$ million (Gates Grant and FLDOE raised matching funds) for a three-year period that started in March 2001. It was designed to provide school leaders throughout Florida with support in implementing school-wide technology plans as part of the required Florida school accountability legislation and to provide principals in public and private schools with access to quality leadership development focused on whole systems change and technology integration.

According to the grant's application, two of the objectives of the project were to: a) adapt, expand, and integrate existing leadership development and technology training; and b) create an interactive professional network of school leaders using technology to communicate, collaborate, solve common problems, and share innovative lessons. An important aspect of the FloridaLeaders.net professional development model was the use of a "one-on-one mentoring" strategy. This mentoring component was facilitated and implemented by retired school principals. After receiving intensive training in mentoring skills, leadership and especially technology integration, these retired school principals provided comprehensive professional mentoring at the school site for in-service principals.

The FloridaLeaders.net project is a unique professional development model that included the following components (www.floridaleaders.net):

1. Mentoring of in-service principals by experienced, retired principals. This component gives credibility to the professional development model and benefits current principals by providing a mentor who not only knows the 
profession but also has acquired extensive knowledge in technology and its potential application in the educational setting. Creighton (2002) indicated that school districts are capitalizing on senior administrators' expertise to provide mentoring programs for their beginning principals, especially when trying to navigate the particularly difficult problems that all principals encounter such as technology integration. These experienced, retired administrators would also be influential in training current veteran school leaders who are still working.

2. Peer interaction between participating principals to model a planning process for integrating technology into the educational setting of their schools. Principals work in small groups to explore, through a case study format, challenges and opportunities to integrate technology. As McKenzie (1998) noted, peer interaction is very powerful and allows professionals with similar interests to get together and collaborate, brainstorm, and solve common problems.

3. Hands-on applications of technology during an intensive three-day professional development session in technology, as well as during web-based, technology driven follow-up sessions. Each principal received a state-of-theart lap top computer and a top of the line Palm Pilot, for personal and professional use.

4. Partnership between the FLDOE and the Gates Foundation emphasizing the shared commitment between private and public sectors for technology integration in education. 
At the outset, the FloridaLeaders.net project appears to have the necessary components for an effective professional development model that would equip school administrators with the appropriate leadership for a successful integration of technology at their schools. In other words, principals would have the necessary knowledge to lead their staff in integrating technology in schools. DuFour and Eaker (1998) concluded that the success of school improvement efforts depends on the professionals within the schools. Principals can create conditions that ensure that professional growth is part of the school culture. According to Guskey and Sparks (1996), quality staff development will have a direct effect on administrator's knowledge and practices. This will in turn influence student achievement through administrators' interactions with teachers to provide supervision and support, and by setting school policies regarding curriculum, assessment, school organization, and educational materials (Deal, 1987).

Although the goals of the program are clear, it is necessary to assess the degree to which these goals were achieved. Killion (2002) emphasized the importance of assessing the impact of professional development activities. On the other hand, examination of the literature on the effectiveness of various professional development programs indicates that such programs are not always effective in producing actual change in behavior and practice (Parsons, 2001).

\section{Statement of the Problem}

The important role of the school administrator in facilitating meaningful change in a school is well established (Lieberman \& Miller, 1979; Levine \& Lezotte, 1990; Smith, 1999). The need to provide principals with effective professional development is 
also well established (Killion, 2002). The question is then: How do we know if a professional development program has been effective?

Educators are facing many challenges and are experiencing continuous cuts in their budgets for staff development programs. For example, in February 2005, the Bush Administration's proposed budget for FY06 eliminated completely the $\$ 530$ million that was appropriated in FY05 for the Enhancing Education Through Technology (EETT) program. Therefore it is clear that in the absence of solid proof about the effectiveness of professional development, decision-makers are not funding them and are redirecting their dollars to other programs. Policy makers are asking what the Return on Investment (ROI) is in professional development (National School Board Association, 2004). Other stakeholders are asking additional questions: How do you know when a Professional Development is working? How do you know when it is enough? How do you get hard evidence?

Jack Phillips, an evaluation expert and developer of the ROI process indicated that studies of effectiveness of professional development could justify budgets, improve support for learning development and enhance the design and implementation processes (www.roi.com, Retrieved June 22, 2005). Such evaluations of the effectiveness can also identify inefficient programs that need to be redesigned or eliminated, and identify successful programs that can be implemented in other areas. Evaluation is therefore a critical aspect of any staff development program (Patton, 1997). Furthermore, Dennis Sparks, Executive Director of the National Staff Development Council, indicated that the documentation of the connections between staff development and improvement of student learning is becoming more crucial. 
For example, in the EETT program, the US DOE requires states and districts to measure how their technology programs are: a) integrating technology into curricula and instruction, $b$ ) increasing the ability of teachers to teach, and c) enabling student achievement to meet challenging state academic standards (www.iste.org).

In education, answering the above questions has perplexed educators for years and has not led to well-documented answers. Ann Marcus, Dean of the School of Education at New York University, during an evaluation forum assessing professional development (1999), indicated that professional development is one of the most elusive subjects in education and one of the most important. Despite the complexity of the assessment of professional development, educators have kept trying but without much success. Guskey and Sparks (1996) indicated that although it is generally assumed that there is a strong and direct relationship between staff development and improvements in student learning, efforts to clarify that relationship have met with little success.

For example, in a study that the Florida Department of Education conducted to evaluate the Floridaleaders.net project, there were a variety of shortcomings that do not allow for conclusive decisions about the effectiveness of the project. Specifically, the study relied on self-reports, and did not include a comparison group.

This study brought new elements o the evaluation of the FloridaLeaders.net project. Specifically, it involved stakeholders who participated in the program, as well as those who did not participate in the program. The study was based on a set of technology indicators (dimensions) derived from nationally defined standards. These standards were used to gauge the level of integration of technology in schools. Finally, this study collected data from multiple sources, using a larger sample size and comparison groups. 
The purpose of this study was therefore to investigate the effectiveness of the FloridaLeaders.net project. Specifically, the study compared the technology integration of schools whose principals have participated in the FloridaLeaders.net program with schools whose principals have not participated in the program.

\section{Research Questions}

The main research question of this study was: Has the Floridaleaders. Net professional development model been effective in integrating technology in public elementary schools?

In order to answer this general question, the following three subsidiary questions were asked:

1. What is the difference in technology use in management and operations between schools whose principals participated in the FloridaLeaders.net and those who did not participate?

2. What is the difference in the use of technology in the learning and teaching environment in schools whose principals participated in the FloridaLeaders.net and those who did not participate?

3. What is the difference in the use of technology in the assessment and evaluation of students' learning in schools whose principals participated in the FloridaLeaders.net and those who did not participate?

\section{Significance of the Study}

The role of the principal is a crucial factor in the successful use of technology in schools (Office of Technology Assessment 1999). Bailey (2002) noted that the success of 
how school administrators use and understand technology tools might well determine the economic, political, and military survival of America in the $21^{\text {st }}$ century.

The purchase and installation of hardware and software are not significant indicators of effective implementation of technology in schools (Gordon, 2000). A more significant indicator is the technological know-how of the school's faculty and staff. In fact, according to the CEO Forum on Education and Technology (1999), the transformation of school technology from hardware equipment and software programs into tools for teaching and learning depends on the knowledge and motivation of the educators who are committed to use technology to prepare students for the $21^{\text {st }}$ century. The leadership in a school greatly impacts the outcome of technology integration. Many principals, however, do not have the technical understanding or skills to recognize the potential of technology and how to effectively integrate it into the classroom.

Several publications (Smith \& Andrews, 1990; Peterson, 2002) noted that principals who do not understand how to use technology make poor decisions and spend considerable amounts of money on equipment, without achieving a successful integration of technology in their schools. It is therefore critical for school principals to understand both the capabilities and limitations of technology. Pflaum (2004) indicated that this understanding is necessary to help administrators in the planning, budgeting, purchasing, distribution, and maintenance of an-up-to-date technology that is best suited for their needs. Consequently, as stated earlier, policy makers, educators, and other stakeholders from public and private sectors are investing heavily in the use of technology in education. They are also spending scarce dollars to fund professional development activities, and therefore, it is imperative to evaluate and assess these programs to 
determine their effectiveness in using technology to improve student achievement (Killion, National Staff Development Council, 2002.)

Evaluation studies specific to the FloridaLeaders.net project have been limited if not absent. This study, therefore, seeks to investigate the effectiveness of this professional development program for school principals to facilitate the integration of technology in elementary public schools.

\section{Assumptions}

The basic assumptions in conducting this study are the following:

1. It is assumed that the principal, the teacher, and the media specialist samples are representative of their respective populations in the district where this study was conducted.

2. It is assumed that the respondents and the researcher have the same understanding of the language and terms used in the data collection instruments.

3. It is assumed that the participants in this study will provide honest and accurate responses to the questions in the instruments. Every effort was made to reassure the respondents of the confidentiality of the data.

4. It is assumed that the FLN professional development project will have a direct effect on principals' knowledge and practices regarding educational technology. This will in turn impact student achievement through the principal's interactions with teachers in providing supervision, support and, by setting school policies regarding technology use in curriculum, assessment, and school operations (Peterson, 2002). 
This study was conducted with the realization of the following limitations:

1. This study is causal-comparative and the random assignment of participants was not possible.

2. The design of this study is limited to the assessment of technology implementation in elementary schools based on the participation or nonparticipation of their principals in the FloridaLeaders.net program.

3. The design did not control for the existence (if any) of other technology programs similar to the FloridaLeaders.net program.

4. The accuracy of the participants' responses depended on their ability to recall past events and assess the current environment.

\section{Definition of Terms}

For the purpose of this study, the following are definitions of the terms used. Other terms will be explained as they are introduced.

Educational Technology. Encompasses knowledge about and use of computers and related technologies to: a) develop, deliver, and assess instruction; b) use computers as an aid to solve problems; c) manage school and classrooms tasks; d) conduct educational research; e) access and exchange information electronically; f) enhance professional productivity; and g) promote computer science education (www.iste.org).

FloridaLearders.Net (FLN). An $\$ 11$ million, three-year project designed to provide school leaders throughout Florida with support in implementing school-wide technology plans as part of the required Florida school accountability legislation. The FL 
DOE was awarded a grant from the Bill and Melinda Gates Foundation to fund the FloridaLeaders.net project.

International Society for Technology in Education. A nonprofit professional organization with a worldwide membership of leaders in educational technology focusing on promoting appropriate uses of technology to support and improve learning and teaching in PK-12 institutions.

Instructional Software. Computer programs developed to assist students to learn new content, review content already learned, or assess current knowledge. These programs help teachers and students to demonstrate concepts, perform simulations, and record and analyze data (NCES, 2000).

Media Specialist. A professional position, based at the school, responsible for assessing and meeting the needs of students and faculty for information and for developing programs to stimulate students' interest in the use of technology and multimedia resources.

National Educational Technology Standards for Teachers. A publication of the International Society for Technology in Education that identified what teachers should know about and be able to do with technology. The document also provided models for incorporating technology in teacher preparation programs and examples for teachers on how to use technology effectively to improve students learning (http://www.iste.org).

Policy of Acceptable Use of Technology. Policy designed to define the ways in which a technology resource can be used. It generally includes statements about the required procedures, rights, and responsibilities of a technology user. Users are expected to acknowledge and agree to all the conditions of the technology use (NCES, 2000). 
Professional Development. Refers to a set of activities to enhance professional career growth of an individual. These activities may include individual development, continuing education, in-service education, peer collaboration, study groups, and peer coaching and mentoring. Fullan (2001) defined professional development as both formal and informal learning experiences in a person's career until retirement. Grant (2003), on the other hand, suggested an even broader definition to take into consideration the use of technology and indicated that professional development include formal and informal means to help educators to learn not only new skills but also to help them develop new insights, and explore new understanding of content and resources especially in the use of technology to support inquiry-based learning, and improve student achievement.

SurveyGold. A software system for building and administering surveys online. The software allows users to quickly create and conduct surveys over the Web. Users can export data to Excel, SPSS, and other formats, and publish formal reports via wordprocessing programs, such as Microsoft-Word.

Technology Dimension. The meaning or value assigned to a variable to measure a condition in terms of its ability to demonstrate and/or show something.

Technology Downtime. The amount of time a technology component (hardware, software, or communication) is not available for use.

Technology Infrastructure. The amount of technology hardware and software available at a school.

Technology Standards for School Administrators Collaborative. A partnership between a group of leading professional organizations specializing in educational technology, including, the International Society for Technology in Education, the 
National Association of School Principals, the American Association of School

Administrators, the National School Board Association, and several state departments of education and universities. In November 2001, the Collaborative released the TSSA document, which defined national standards on what school administrators should know and do to effectively use technology in schools. The dissemination and implementation of these standards were supported by more than twenty additional participating organizations (see Appendix A).

\section{Summary}

This study investigated the impact of the FloridaLeaders.net professional development project on integrating technology in elementary schools. The study compared a group of schools whose principals have participated in the FloridaLeaders.net (FLN) program with schools whose principals have not participated in the program. The study focused on investigating the degree to which this project facilitated the integration of technology into the schools. Three areas of technology use were investigated: a) the use of technology in management and operations, b) the use of technology in the teaching and learning environment, and c) the use of technology for assessment and evaluation.

The National Technology Standards for School Administrators and the National Technology Standards for Teachers were be used as the framework to assess technology integration. 


\section{CHAPTER II}

\section{REVIEW OF THE LITERATURE}

Technologies, especially, computer technologies have revolutionized the way people live, function, and interact with other people. The exploding increase availability of technology (sophisticated computers, internet, cell phones, digital cameras, digital subscriber lines, wireless equipment, etc) has challenged teachers, school administrators, and other educators to take advantage of these new resources and use it to efficiently educate students and prepare them to become productive citizens and have a better life. However, there are several challenges associated with this vast array of technological resources in education that need to be addressed. For example, what is the appropriate use of technology in an educational institution? What is its effectiveness in improving teaching and learning? What is the role of the educational leader in the technology era, how to maximize the return-on-investment in technology? and How to minimize the negative "side effects" of technology in education?

This literature review includes several sections discussing various aspects of educational technology and professional development. These aspects are: a) current applications of technology, b) brief history of educational technology, c) current status of educational technology, d) investment in educational technology, e) challenges and opportunities in educational technology, f) the human capital in educational technology, g) the need for professional development in educational technology, h) the role of the principal in educational technology, i) the need for professional development, $\mathrm{j}$ ) elements 
of quality professional development, $\mathrm{k}$ ) evaluation of the impact of professional development in educational setting, and 1) conceptual framework of the study.

\section{Current Applications of Technology}

Technology is rapidly emerging and increasingly becoming an integral part of all the aspects of life in the $21^{\text {st }}$ century. It is difficult to imagine any sector (transportation, communication, business, education, medicine, etc...) functioning without the use of technology. For example, a person cannot access his or her own money when the bank's computer is down.

In fact, a few years ago, today's usages of technology, would have been considered to be in the realm of science fiction. For example, in the area of miniaturization of the design of digital equipment, scientists are exploring the new frontiers of nano-technology and creating devices called nano-tubes to replace wires and other connectivity devices used in exceedingly small electronic devices. These nanotubes are about 10,000 times thinner than a human hair, yet stronger than steel, more flexible than plastic, and conduct energy more effectively than almost any other material (www.research.ibm.com/topics/popups/serious/nano/html/nanotubes.html, Retrieved November 17, 2004). In the field of biotechnology, Australian scientists have discovered a way to track the electronic path of a single thought traveling through the human brain. This technological discovery may very well revolutionize the field of education and the way students are taught. Specifically, scientists assert that when a student is asked to read a sentence for example, his or her processing of that sentence can be observed and tracked. According to scientists at the Melbourne Institute for Brain Research, this discovery will allow educators to monitor how students are learning new concepts and 
consequently assist children to achieve their full potential as quickly as possible (www.abc.net.au, Retrieved November 29, 2004).

This technology revolution is continuing at a fast speed and is confirming what Andrew Grove predicted in 1996 when he stated, "we are only at the beginning of the technology revolution and the best in technology is yet to come. In the area of microcomputing for example, it is expected that by 2011 , microprocessors will have a computing power that will be 1,000 times the power of today's computers. (www.ucal.edu, Retrieved June 13, 2005).

Even well known industry leaders such as Thomas Watson, Chairman of IBM, who thought in 1943 that there was a world market for maybe five computers, did not predict the scale and scope of this revolution. Ken Olson, President and Chairman of Digital Equipment Corporation, also indicated, as late as 1977, that there is no reason why anyone would want a computer in his home.

The previous two examples show that while it is difficult to predict what the future of technology would be, we are certain that we are in the throes of a technology revolution that is affecting all aspects of our lives. Additionally, with the industry efforts in multimedia, satellites, Internet, nano-technologies and telecommunication, experts predict that technology will be as essential to the lives of ordinary individuals as food and water are to their survival.

\section{Brief History of Educational Technology}

Technology has been used in education since the early 1900s. Over the years a variety of different labels such as audiovisual instruction, educational technology, and instructional technology have been used. However, because of the constant and rapid 
development and expansion of technology and technological resources, these definitions have also kept changing. The roots of this field go back to the early twentieth century, when educational film was first being produced (Gordon, 2000). From the early 1900s through late 1920s, public schools experienced an increase in the use of visual materials such as films, pictures, and lantern slides which led to the birth of what is now known as the visual instruction movement and was re-defined to include all types of visual aids such as flat pictures, charts, maps, stereographs, stereopticon slides, and motion pictures.

As a result of technological advances in audiovisual media such as sound recording, radio broadcasting, and motion pictures during the late 1920s through the 1940 s, the focus of the field became audiovisual instruction. However, during the 1950s, 1960s, and 1970s, educators and intellectual leaders shifted the focus of the field of instructional technology from emphasis on media to emphasis on the process. In other words, instructional technology was seen as a way of looking at instructional problems and examining feasible solutions to those problems using technological resources. Other intellectuals and educators shared this view and indicated that instructional technology is a process that could be thought of as the application of science to instructional practices (Gordon, 2000). These definitions kept changing and the focus kept targeting the importance of both nonhuman and human resources for instructional purposes. In 1977, the Association for Educational Communication and Technology (AECT, a.k.a.

Department of Audiovisual Instruction in 1960s) adopted a very lengthy definition of the field consisting of sixteen statements, one of which was:

"Educational Technology is a complex, integrated process involving people, procedures, ideas, devices, and organization, for analyzing problems and devising, implementing, 
evaluating, and managing solutions to those problems, involved in all aspects of human learning" (AECT, 1977). A closer look at this definition reveals the emphasis on people, materials, and devices, reinforcing the notion that the field of instructional technology is not limited to the development and use of technology infrastructure.

During the period between 1970s and 1990s, the field of instructional technology continued to be affected by the development of new educational theories such as behavioral learning and constructivist learning, and also by the technological advances such as CD-ROM and the Internet. As a result, a great interest in distance learning, online education, and collaborative learning was developed. This shift led AECT to revise and publish the following new definition: "Instructional Technology is the theory and practice of design, development, utilization, management, and evaluation of processes and resources for learning" (Seels \& Richey, 1994, p.1). This definition reveals the presence of five domains: design, development, utilization, management, and evaluation, which are linked in a non-linear fashion to the hub of "Theory and Practice" (Seels \& Richey, 1994).

\section{Current Status of Educational Technology}

Technology continues to increasingly play a vital role in teaching and learning, in management and operation, and in preparing students for the technological society of the $21^{\text {st }}$ century. Various stakeholders are requiring technology in education as can be seen from the results of a survey conducted by Microsoft/Intelliquest in 1995 that showed that $89 \%$ of parents believe computer skills are important to educational success, $86 \%$ of children believe computer skills are important to getting good grades in school, $92 \%$ of children think computer skills will help them earn higher salaries in future jobs, $77 \%$ of 
teachers think computers help each child learn at his/her own pace, and $61 \%$ of Americans believe that computers help develop kids' creativity.

Furthermore, a survey conducted by the National Association of Secondary School Principals (Education Daily, August 19, 1996), found that in 1983, students believed that mathematics and English were the most important courses offered in school; computer barely made the list. In 1996, students ranked computer use and programming as the third most important course, and $92 \%$ of the students ranked computer use and programming as very important.

The continuing decline in the price of technology equipment and its continuing increase in power created the conditions for the invasion of technology in education at all levels (Means, 1997). For example, in 1981, only 18 percent of U. S. public schools had one computer for instructional use. By 1991, that percentage increased to 98 percent (QED, 1992). In 1994, about 53 percent of all school districts reported they had at least one school connected to the Internet (QED, 1995), today it is nearly impossible to find one school in the US that does not have Internet connection.

\section{Investment in Educational Technology}

In addition to educators and businessmen, policy makers and politicians are also realizing the need to fund and promote the use of technology in American schools. For example, in 1994 the passage of the Improving America's Schools Act, the U.S. Congress started by appropriating $\$ 45$ million and continued to increase funding to enhance the use of educational technology in schools throughout the nation. It is estimated that the funding of technology in education that was appropriated through the U.S. Department of Education alone, not including private foundations, state departments 
of education, local districts and schools, exceeded one billion dollars. These investments in technology in education continue to increase in volume and in sources of funding. The No-Child-Left-Behind (NCLB) legislation appropriated a considerable amount of funding for the use of technology in education in order to prepare students to function in a technology-rich society and to enhance and support instruction in America's classrooms and to improve student academic achievement.

Many colleges, universities, and K-12 institutions throughout the world are investing heavily in these digital technologies expecting great returns in terms of increased student performance and enhanced educational environments. For example, in 1999 , the spending in multimedia digital technology in K-12 schools in the U.S. was estimated at $\$ 7$ billion (Kleiman, 2000). This considerable investment was required for the purchase of computer hardware and software, the installation of networks and servers, and the payment of Internet access and other services.

The question now is, "Will these huge investments in technology improve the education of students?" Will it make the educational systems more effective and efficient? Will it help schools prepare students for better lives in the $21^{\text {st }}$ century and beyond? These large investments are mainly based on the "potential" of the new technologies in the field of education, somewhat similar to the investments on the "dotcom" companies or the "stock market" which are also based on "potential" great returns for the investment. Investing in technology in education requires a clear vision of goals and objectives, a well-developed plan, and a coherent implementation. The expected outcome would be an integrated technology system that supports the educational function of the school or the institution of learning. 
The technology explosion in education, while bringing potential promises, has brought about many struggles and challenges. In terms of potential, technology may provide the educator (teacher and/or administrator) with great flexibility and unmatched convenience for the discovery and exchange of information, communication, management, exploration, learning, and teaching (Hamza et al., 2000).

Technology allows many administrators to manage their resources more efficiently (budgeting, scheduling, communicating with parents, and record keeping) and assists them in data analysis in the decision making process (Oberg et al., 2000).

Teachers may also use technology to take students beyond traditional classroom limits and to create virtual environments to experiment and explore. According to Trotter (1999), technology should be utilized as an object of inquiry.

Technology can challenge higher order thinking and problem solving tasks; students are encouraged to explore and to learn by discovery. Technology can, with continuous feedback from teachers, provide the learner with more control over his/her learning process through self-paced, self-regulated learning at any time or any place (Alhalabi et al., 1999).

In terms of challenges, the question of whether educators have the necessary knowledge to effectively use these technologies arises. Do decision-makers master the fundamentals of information technology systems that qualify them to make critical decisions? How do these decisions impact learning and teaching? What involvement do faculty, staff, students, and other stakeholders have in technology issues affecting the school (Alhalabi et al., 1999). 
While educational institutions have invested significant amount of money and resources in technology infrastructure (technology hardware, technology software, wiring, other upgrades to the physical plants), they generally ignored the human capital that will be using this technology (Hamza et al., 2000).

In a continuous changing environment that is characterized by a heavy technology presence and an increased need to operate in an information-intensive society, educators must be equipped with the appropriate "know-how" of technology. Teachers for example need to change the way they teach and make use of the potential of technology to meet the expectations and needs of an ever-increasing diversity of learners. The traditional question "What is worth knowing or teaching" becomes extremely complex (Kauffman \& Khalid, 1998).

Teachers are under extreme pressure from several stakeholders, especially students to use tools such as the Internet, multimedia, and educational software in the classroom and even outside the classroom to communicate with parents, students, and maintain a "quality" website. It is becoming a reasonable expectation for students to request that their teachers post the course materials, assignments, and even grades online. It is important for teachers to be able to meet the demands of their students and to think of creative ways to use technology to enhance the learning process and be at the same time the expert in the core content of the course.

Furthermore, with the explosion of new technologies, principals need to be better prepared to act in a fast-paced environment that requires them to scan, digest, assess, and make decision based on a myriad of information. The continuous stream of new 
technology products that enter the schools generates the need for the continuous learning required of educators. Technology by itself does not change teaching, but teachers and principals do. It is through educators' creativity and energy that technology is integrated into the classroom (Mehlinger \& Powers, 2002).

The Need for Professional Development in Technology

According to Hamza (2000), in the absence of a strong and continuous support, such as quality professional development, technology may become an overwhelming hurdle that can be misused and may even stand in the way of teaching and learning. Therefore, it is vital to have a system of continuous professional development to allow educators to become educated users of technology.

Professional development allows teachers to design and develop instructional models that make use of the capabilities of technology and help them understand major concepts, ideas, and theories in education to assist in the overall design, delivery, and evaluation of instruction (Roblyer \& Edwards, 1997). The amelioration and adaptation of the educational system can be achieved through a comprehensive "360 degree" professional development model that includes all stakeholders: the trainers who will be training the teachers, administrators, and staff members need professional development. The teachers who will in turn facilitate the use of technology in the classroom need professional development. Teachers are expected to help students to effectively use technology to self-test, self-question, and self-regulate learning, and create solutions to complex problems (Hamza, 2000). Administrators will understand the potential of technology, and will support and create an environment conducive to the effective use of technology in the school and therefore need professional development. 
The potential and expected benefits of using technology will be achieved only if all stakeholders, especially principals, have a clear understanding of the potential use of technology in education, and are committed to facilitating its successful implementation at their schools.

The Role of the Principal in Educational Technology

Internal and external factors impacting the schools, such as new legislation at the national or state levels (e.g. NCLB, Title I, Florida Accountability system), demographic shifts, and most especially technology, have put extreme pressure on school administrators to adapt to these changes. Gordon (2000) indicated that these changes have resulted in a turning of the role of principal 90 degrees from everywhere. The school's principal is expected to play the role of an instructional leader to provide the necessary tangible support (such as technology infrastructure and professional development), as well as the intangible support (Buy-ins to the school's technology mission and vision).

It is clear that the role of the principal is crucial in this endeavor. Reitz (1997) stated that, the principal remains the linchpin to adoption and use of technology. How school principals approach and use technology will be a major determining factor in the success or failure of the effective implementation of technology in schools. The role of the principal is extremely important and is the passport to school success (Creighton, 2002).

Principals should have a clear understanding of the opportunities and challenges that would eventually be associated with the implementation of technology in their schools. In terms of opportunities, administrators must realize the potential of technology 
in enhancing the learning environment and in supporting the teaching and learning process to increase student achievement.

In terms of challenges, principals must realize that the use and integration of technology into their schools is a "change" that will most likely face resistance from teachers and staff. The road to change is filled with challenges and is long. Change is a process that takes time and requires developmental growth in both feelings and skills (Hall \& Loucks, 1979). Like any change in any organization, a change in a school needs not only the buy-in of teachers, staff, and other stakeholders, but also their collaboration and their commitment to bringing about this change. Hope, Kelley, and Guyden (2000) concluded that school administrators are indispensable in the process of transforming schools through technology. Principals' roles may range from that of a dedicated fan on the sidelines to that of a visionary on the frontlines who sees what is possible through the use of technology (Byrom, 1998; Guskey, 1999). However, not all principals address changes in the same manner.

According to Hall and Hard (1987) there are basically three types of facilitators of change: initiators, managers, and responders. This classification was based on the level of intervention and the behaviors of these change facilitators.

In the case of principals classified as "initiators", Hall et al. found that this type of principal publicly demonstrates a strong vision of where the school is heading and what is best for students and teachers. They have clear and high expectations for the staff, faculty, students, and parents. They lead by example and continuously use several effective forms of communication. 
In the case of principals classified as "managers", Hall et al. found that this category of principal focuses on the administrative aspects of the school and is more concerned with the efficiency of the procedures in place and the organization of the current system. They also tend to resist change and want to implement only changes that were proven to have worked in other schools or are required by district, state, or federal authorities.

In the case of principals classified as "responders", Hall et al. found that this type of principal focuses more on the current concerns of faculty, staff, and the community. They do not take initiatives and deal with issues as they arise without looking at the big picture or being pro-active in anticipating issues. In simple terms, Hall et al. basically categorized these three types of principals as: a) principals who "make things happen" or initiators, b) principals who "help things happen" or managers, and c) principals who "let things happen" or responders.

It is then necessary for the effective implementation of technology in schools to have principals who are "initiators" and who "make things happen." This is important especially in light of the fact that several studies concluded that school principals are not ready to be effective in implementing technology in their schools and continue to be the major barrier to bringing schools into the information age (Bailey \& Bailey, 1995).

Fatemi (1999) and the Panel on Educational Technology (1997) agreed that the lack of professional development for technology use is one of the most serious obstacles to fully integrating technology into schools. This is mainly due to the fact that many schools feel pressured or intimidated by the rapid development of technology and end up allowing an influx of technology into their classrooms without a clear vision and careful 
planning to maximize the return on investment in this rapidly changing field. Educators and administrators often make decisions based on misconceptions or myths about how to make the best use of technology in their educational settings. For example, the following are some of the misconceptions and myths about technology in K-12 schools (Gordon, 2000).

Some educators believe that putting computers into schools will directly improve learning, that is, the greater the number of computers, the greater the improvement in learning (Kleiman, 2000). This myth is easily challenged by the fact that few teachers are adequately trained in technology to implement a technology-based curriculum and even fewer know how to develop curriculum around technology. The hardware and software must go hand in hand with training, support, and the teacher's ability to effectively use these tools.

Other educators believe that there are agreed-upon goals and best practices that define how computers should be used in K-12 classrooms (Kleiman, 2000). This myth can also be easily challenged because of the fact that different students have different learning styles and the application of technology varies accordingly. According to the multiple intelligence theory, each human being possesses at least eight forms of intelligence, which Gardner (1993) labels as linguistic, logical-mathematical, musical, spatial, bodily kinesthetic, naturalist, interpersonal, and intrapersonal. Gardner (1993) continues to explain that every human being possesses a combination of these eight intelligences, but because of genetic differences and experiences, no two human beings have the exact blend of these combinations. To that end, educators should take advantage of these multiple learning styles and abilities of students and should use technology that 
takes this diversity into consideration and consequently should avoid purchasing software of the type "one-size fits all."

A third myth is that some educators believe that once teachers learn the basics of using a computer, they are ready to put the technology to effective use. The reality for this myth, as documented in a long-term study of the Apple Classroom of Tomorrow (ACOT, 2000), is that for technology to be effective in $\mathrm{K}-12$ schools, considerable professional development must take place over years to impact teaching styles, curriculum content, classroom management, and student assessment. Professional development must be continuous and rigorous to move teachers from the entry stage to the invention stage as the ACOT study reported. Specifically, the ACOT study identified five stages of "instructional evolution" for using technology (Kleiman, 2000): a) the entry stage where teachers experience hesitation and question whether computers will ever be effective in their classroom; b) the adoption stage where teachers start to use general drill-and-practice software that may seem to fit into the curriculum; c) the adaptation stage where teachers fully integrate technology in traditional classroom practices by using software such as databases, presentations, spreadsheet, and content specific software such as the Geometer Sketch Pad; d) the appropriation stage where teachers fully understand technology and see it as indispensable in their classrooms; and e) the invention stage where teachers engage students in multi-disciplinary projects involving several subject areas and where technology is an integral vehicle and platform. At this last stage, the study reported that students of these teachers showed high level of skills with technology and developed an ability to think critically and work collaboratively. 
A final myth is that some educators believe that educational equity can be achieved between students in poor and rich schools if they provide the same computer-tostudent ratios at these schools. This is a very narrow view of reality. In fact, (Gordon, 2000) have indicated that teachers in wealthier schools are more knowledgeable about technology than their counterparts in poorer schools. Teachers in rich neighborhoods are challenged more by their students than their counterparts in poorer neighborhoods. Furthermore, unlike poor students who have access to technology only at school, students with high socio-economic status have access in their homes to even more sophisticated technology.

The Need for Professional Development

According to Sparks (2002), quality staff development will have a direct effect on administrators' knowledge and practices. This will in turn influence student achievement through the administrator's interactions with teachers to provide supervision and support and, also, by setting school policies regarding curriculum, assessment, school organization, and educational materials (Peterson, 2002).

A quality professional development program must contain all the necessary components that research has found to be important. However, even professional development activities designed based on universal principles, such as that of the National Staff Development Council, their content and processes must be adapted to the unique characteristics of the setting (Fullan, 1994). According to Joellen Killion, director of special projects for the National Staff Development Council, professional development in a technological age requires new definitions and new resources. Traditional sit-andget training sessions or one-time workshops have not been effective in using technology 
in schools. Instead, a well-planned, ongoing professional development program that is tied to the curriculum, designed with built-in evaluation, and sustained by adequate financial and staff support is essential if technology is to be used effectively to promote learning and improve student achievement.

\section{Elements of Quality Professional Development}

A review of the literature revealed that "quality" professional development for technology use and integration in schools should be based on findings of research and should address at least the seven primary topics that the Technology in Schools Task Force authors have determined to be central in the effective use of technology in educational institutions. Specifically, a quality technology professional development should assist and equip principals with the necessary knowledge and understanding to address the following questions: a) how to develop and implement a technology plan; b) how to finance and how to budget for technology programs; c) what type and how much equipment and infrastructure are needed; d) what type and how many software applications are needed; e) what type of technology maintenance and support programs are needed; f) what type of professional development is needed for teachers and staff; and g) how to integrate technology into the curriculum and how to measure the impact on student achievement.

\section{Development and Implementation of a School Technology Plan}

A quality technology professional development for school administrators should help principals to understand the need for a technology plan. Technology planning is a crucial factor and a fundamental issue that needs to be addressed and resolved in order to 
achieve successful technology integration in a school (Levine, 1998; MacNeil \& Delafield, 1998).

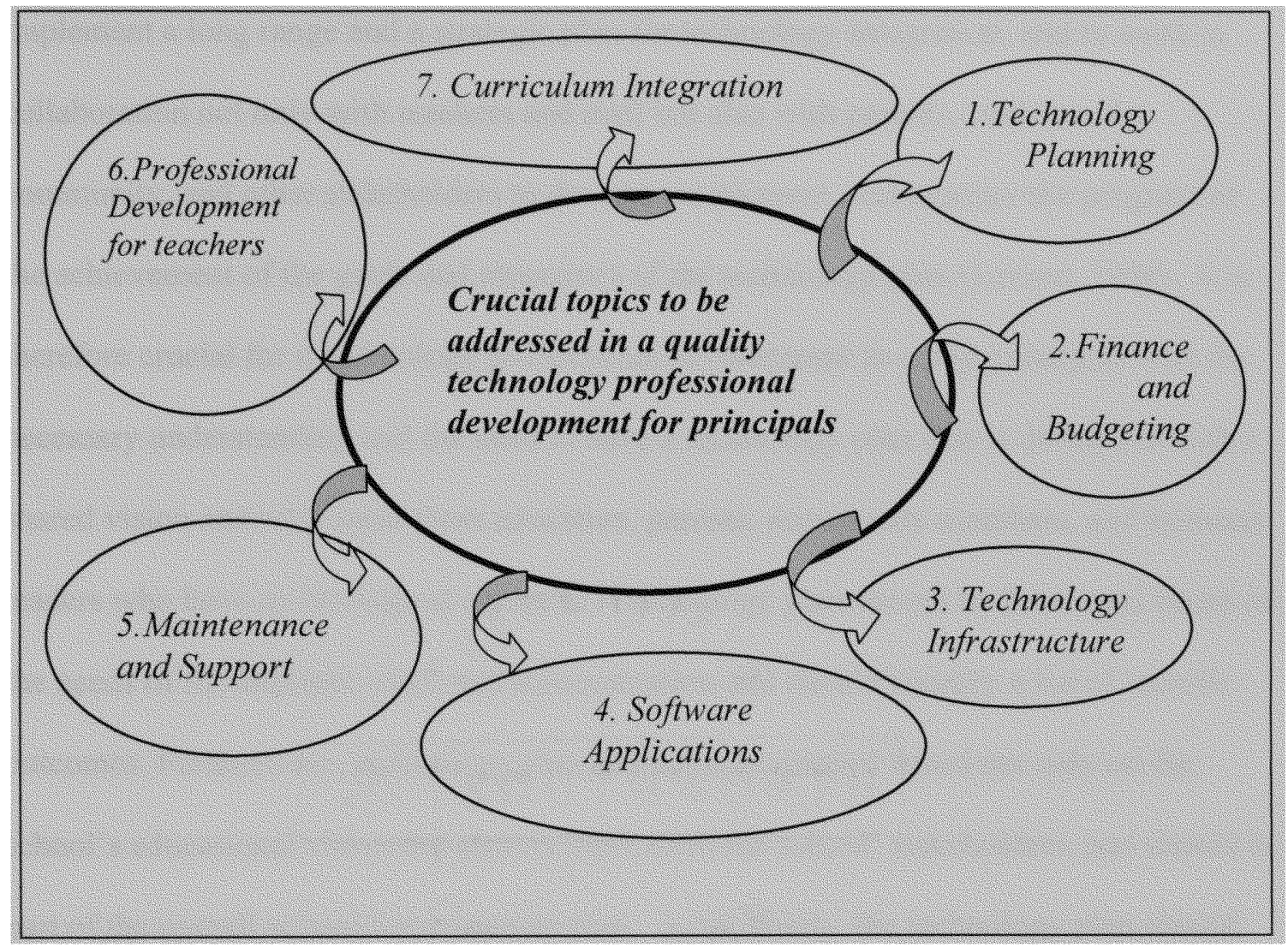

Figure 1. The seven topics identified by the Technology in Schools Task Force to be central in the effective use of technology in educational institutions.

The number of technology equipment or the sophistication of the software applications or even the number of technology knowledgeable personnel cannot measure the success of a technology program in a school. Rieldl, et al. (1998) argue that despite the presence of technology equipment, schools are not prepared to integrate computer technology into their everyday instruction because of the absence of a coherent and a comprehensive technology plan. It is necessary to have a technology plan that defines the technology policy for the school, sets the technology goals, collects the technology data, 
identifies the resources to implement the technology plan, prioritizes the technology goals and objectives, and continuously evaluates the process. It is important for principals to implement a long range and a strategic plan for technology integration, and to work in collaboration not only with teachers and staff but also with parents, students, the community, and other stakeholders to develop, implement, and monitor the progress of the achievement of the goals and objectives of the technology plan (Levine, 1998). It is therefore crucial for a technology professional development to equip principals with the necessary understanding and the need to have a technology plan that is developed with a shared vision and with input from educators, parents, community members, and business leaders who have technological expertise. Technology plan should be developed based on the needs of the students, staff, and administration and should identify a list of specific outcomes. Furthermore, technology plan should be developed based not only on the school's educational vision but also on input from the school' stakeholders, and should be part of the overall school-improvement plan. Additionally, the technology plan should focus on how technology can enhance and improve student achievement. Finally, the technology plan should be reviewed, evaluated to ensure that the desired outcomes are being achieved, and should be updated periodically in light of the continuous changes of the educational environment because of advances in technology and changes in educational policy and teaching methodology.

Financing and Budgeting for Technology Programs

A quality technology professional development for school administrators should help principals to understand how to budget and finance technology programs. Public education today is facing the challenge of having limited funds to meet growing demands 
from its stakeholders. Schools have less and less flexibility on how to spend the money they receive from their school districts, their states, the federal government, or from foundations and private institutions. In other words, the majority of the funding that a school receives comes with many conditions, especially in light of the political demands for better school performance and accountability, and the competition with private and charter schools. Moreover schools today are facing several other challenges that are a result of significant changes such as: performance-based budget allocations, diverse student population with diverse needs, teacher shortage and the need to compete for and retain qualified teachers, increased demands for diversifying educational programs and offering parental choices, and increased interest in the use of new technologies to support the improvement of student achievement.

These demands are associated with major costs and school administrators find themselves more and more struggling to make difficult choices in funding and prioritizing programs. For example, principals are aware of the promising opportunities that technology offers in enhancing the teaching and learning environments, however they have to be creative and also careful not to fund technology at the expense of other more important programs such as attracting and retaining quality teachers. To that end, principals should be equipped with the necessary knowledge and skills on how to effectively fund technology in their schools without compromising other programs.

In implementing a technology program, schools are generally required to fund three phases: a) initial phase of acquiring the technology hardware and software infrastructure, which requires a level of capital expenditure, b) operating phase, which requires an annual budget to run and use the technology, and c) maintenance and 
upgrading phase, which requires both an annual budget to maintain the equipment and a periodic budget to retire and replace a portion of the technology infrastructure to keep it up-to-date. It is then necessary for principals to understand that their technology programs require both capital and operating budgets. The associated operating and capital costs are generally misunderstood, underestimated, or simply not recognized.

Furthermore, a report from the Education Commission (2001) indicated that the majority of State Departments of Education and local school districts continue to underestimate the costs of educational technology. They continue to include only the cost incurred in the first phase of the acquisition rather than the total costs of the three phases, which include all expenses associated with deployment, maintenance, software support, and training. The Education Commission estimates that the acquisition phase represents only about $25 \%$ of the actual lifetime cost of technology integration. The failure to recognize and budget adequately for technology is a likely contributor to the ineffective utilization of technology in the nation's schools. A quality professional development for school administrators should therefore help principals to realize these facts and to seek additional funding and resources for technology such as writing special grants and soliciting funds through partnerships with businesses, and other community agencies.

\section{Technology Equipment and Infrastructure}

A quality technology professional development for school administrators should provide school principals with the necessary understanding of the complexity of the technology system and of the need to provide an environment to ensure the success of their technology programs. The technology equipment and infrastructure in a school refers to computers, digital equipment, cables, networks, Internet connections, and other 
specialized computing and connection devices. For example, computers include desktops, laptops, handheld computers, and mainframe machines. Other equipment includes any equipment that interfaces with computers such as monitors, keyboards, speakers, printers, video cameras, projectors, scanners, digital cameras, and graphing calculators. The technology infrastructure may also include videoconferencing and other distance educational tools, including satellite transmitters and receivers, modems, and other video equipment. It is clear that technology infrastructure may contain several components that seem, at first, to be completely different in function and in purpose such as a printer and a video camera, but in reality they can be linked and are necessary in an integrated and efficient technology system.

Principals must realize also that providing a good technology environment may necessitate the hiring of technical staff to install and maintain technology, the organization of professional development activities to support and assist all staff including teachers and librarians on how to use the equipment and how to integrate it to enhance the teaching and learning process, and may even require a new security system. Indeed, in the area of security, school principals may be faced with two types of security: a) physical security, such as locking the building, installing electronic monitors and cameras, tagging of equipment, and even hiring security personnel, and b) software security, such as anti-virus software, access security, back-up and recovery systems.

Furthermore, quality professional development should give principals a good understanding of the rapid advancements in technologies, which is a sword with double edges. On the one hand, these advancements in technology give greater opportunities to enhance and support the educational vision and mission of the school, and on the other 
hand these same advancements make the life span of the technology infrastructure short and the equipment obsolete within a few years of their purchase. Additionally, advancement in technology necessitates a new way of thinking and requires the establishment of new policies to govern the use of technology ethically and economically, which should be documented and made available to all users in the form of a document that might be called "Policies of Acceptable Use of Technology Resources."

Finally, principals should be encouraged, through professional development, to establish and/or re-enforce relationships with their communities. These partnerships may benefit the schools with technical expertise from technology companies specializing in Internet, computer equipment, networking, or software. The school can also establish partnerships with non-technology companies to secure additional funding; such companies may include department stores, food chains, etc. This strategy will help spread the responsibility for this important and complex endeavor among a larger number of stakeholders.

\section{Software Applications}

A quality technology professional development for school administrators should provide school principals with the necessary understanding of the need for up-to-date, relevant software applications. Software applications in a school refer to computer programs to support instructional and administrative functions. Typically in a school, there are five categories of software applications, which support different functions. Namely, these categories of software applications are:

1. Administrative and management software. These applications are designed to facilitate, and support typical functions that are found in a school such as accounting, 
budgeting, payroll, attendance, inventory control, food services, scheduling, and management of student academic records and attendance.

2. Instructional planning and management software. These applications are designed to assist teachers with their lesson planning, the management of their student academic records such as grading, testing, and the management of the student Individualized Educational Program. This software can also be used to facilitate access to educational resources, or to communicate with students through websites.

3. Instructional and academic software. These applications are designed to assist teachers with their teaching of the academic subjects such as mathematics, sciences, and reading. Specifically, these applications can be as simple as using a word processor to help students with their typing or as complex as an integrated mathematics software such as The Geometer Sketchpad to help students understand, through visualization, complex geometry problems.

4. Communication and networking software. These applications are designed to assist school staff and faculty to use electronic mail, have access to local and wide-area networks, access the Internet, teleconferencing, internet-based telephony, and even satellite uplinks and downlinks.

5. Operating and security software. These applications include the operating systems that run the various computers such as Windows, Unix, and also include security systems such as firewalls, secure transmission system to transmit confidential information (student records), and anti-virus software such as McAfee.

As stated earlier, in the area of software infrastructure, it is also expected from a quality professional development to provide school principals with the necessary 
understanding of these important components. Principals must realize that providing a good technology environment may necessitate the hiring of technical staff to install and maintain the software infrastructure, the organization of professional development activities to support and assist all staff especially teachers in the use of these applications to support and enhance teaching and learning. Additionally, principals should be careful and need to understand that a software application is not only a technical program but it is an automation of a task that was executed manually. This fact necessitates a greater collaboration and dialogue between the technician and the area specialist, such as the computer programmer and the mathematics teacher or even the registrar and the programmer to design a user-friendly and useful product.

\section{Technology Maintenance and Support Programs}

A quality technology professional development for school administrators should provide principals with the understanding of the necessity of technology maintenance and support programs. The technology maintenance program in a school refers to all activities and procedures used to prevent technical breakdowns, to repair equipment, to replace parts, or to update obsolete technology. These maintenance services can be performed in house by qualified school personnel, or by district technical personnel, or by contracting with a private company or contractor. Typically in a school, technology maintenance programs include the maintenance of both hardware and software. The maintenance of the hardware component of a technology infrastructure consists mainly of performing periodic preventive cleaning and inspection, or replacement of faulty components, or upgrading parts and equipment. The maintenance of the software component of a technology infrastructure consists mainly of installing new operating systems and 
networks, and installing new software applications.

On the other hand, the support component is mainly concerned with providing services to users on the actual use of hardware equipment and software. Specifically, the support consists of helping users with basic questions which could be answered through a help desk system or through consultation of a database of frequently asked questions or even to direct the user to a specific location or person to get the service requested. These types of basic services are different from specialized technology professional development. As with the case of hardware, these support services could be performed in house or through a technology support contract or agreement.

It is therefore expected of school administrators to understand the need and the importance to have a technology maintenance and support program. Technology in the school setting must be viewed in similar manner as it is viewed in business. In other words principals must reduce as much as possible the time when technology (network, equipment, internet access, etc) is not available for teachers and students because of breakdowns, and consequently view this downtime as lost valuable instructional time which is comparable to lost sales in the business context. Furthermore, school administrators must keep monitoring key indicators to assess the quality of the maintenance and support program in their schools, such as a log of maintenance incidents, the amount of technology downtime, a procedure for backup of data and recovery from serious disasters, and a system of replacement and upgrades. Additionally, principals should have an understanding of the causes of the technical incidents or malfunctions of technology in their schools. These incidents could be caused by human error, software failure, or hardware failure including networking and communication. 
A quality technology professional development for school administrators should provide school principals with the necessary understanding of the vital role of professional development for teachers and staff. The success of technology implementation in schools depends greatly on the assistance and the active involvement of teachers. Teachers have the primary responsibility of integrating technology into the curriculum, and aligning it with student learning outcomes, and most importantly implementing it in the classroom with students. Teachers represent the executers of any technology plan or initiatives at the classroom level. They are similar to the qualified factory workers or specialized construction workers who transform a blueprint of a building on a piece of paper to a "reality building" with livable space and comfort. It is that quality that is of most importance in impacting student learning. Darling-Hammond and Berry (1998), asserted that teacher quality is the factor that matters the most for student learning.

It is therefore apparent that professional development for teachers is a crucial factor in using technology to improve the quality of learning in the classroom. Technology professional development should emphasize and explain the new and expanded role of the teacher in the new era of the technology-rich educational environment. This new role for teachers requires the use of technology inside and outside the classroom to support teaching and learning. Inside the classroom teachers assume the role of coach or facilitator while students work in collaboration (Jones et al., 1995; Valdez, 1998; Kupperstein, Gentile, \& Zwier, 1999).

Outside of the classroom teachers use technology to communicate with students, 
parents, and collaborate with other teachers. In communicating with students, teachers can expand their teaching hours beyond those spent within the walls of the classroom, and also increase their availability and access to their students. In communicating with parents, teachers can enhance interactions with parents and keep them informed at all times of what goes on in the classroom and engage them to support and collaborate in the improvement of student achievement. In collaborating with other faculty, teachers can use technology to work together on projects or exchange ideas and academic information about students and share best practices. This will bring teachers to work together in finding solutions to common problems and in serving as peer advisors, and in providing mentoring and coaching (Lieberman, 1996; Little, 1982). This collaboration is not limited to teachers within the same school, but it can be expanded, through telecommunication, to teachers from different schools within a given school district or state or even nationally and internationally (Kosakowski, 1998).

Technology professional development for teachers must therefore be structured to include relevant and concrete examples on how to use technology inside and outside the classroom. Furthermore professional development must provide continuous feedback, support, and long-term follow-up (Speck, 2001). This is far different and more efficient than the traditional one-time intervention and activities. This statement is supported by research, which indicates that adult learners assimilate and incorporate new skills and knowledge better when it is presented overtime with continuous feedback and follow-up.

Teachers need practical demonstrations to show them how to use the new technology-based strategies in their own classrooms. Then, teachers need opportunities to put into practice what they have learned through hands-on experience in using the newly 
acquired skill or knowledge (Guhlin, 1996; Yocam, 1996). Speck (2001) concluded that quality professional development is a long-term process and that teachers need time to learn the new skills, need time to develop and implement materials and techniques using the new skills, and need time to assess the outcome and impact of the integration of the new skills. In short, Speck estimates that significant change in educational settings, as a result of professional development, could take four to seven years, and in some cases longer. This is extremely important for administrators to understand and to take this fact into account when developing and providing teachers with professional development programs.

\section{Technology Integration into the Curriculum and its Impact on Student Achievement}

A quality technology professional development for school administrators should provide school principals with the necessary understanding of the importance of technology integration into the curriculum. The ultimate goal of any innovation or change at any school is to improve student achievement. In particular, professional development must be designed to ultimately improve student learning (Speck, 2001). Many educators consider increase in student achievement as the most important reason for participating in professional development activities. They also believe that professional development should provide them with the necessary skills to use technology and also with the necessary connection and applications in the classroom. In other words, they want to have opportunities to help students develop higher-order thinking and problem-solving skills (National Staff Development Council, 2002). Furthermore, principals should be catalysts, facilitators, and enablers for teachers to implement technology-supported techniques, to help students work collaboratively and develop higher-order thinking 
skills. Professional development should ultimately translate into an engagement of all students in the learning process including students who have special needs and exhibit various learning styles.

\section{Evaluation of the Impact of Professional Development}

Evaluations of effectiveness of professional development activities, although crucial, are difficult to conduct. Joellen Killion, an expert in the field from the National Staff Development Council, noted, "Professional development is very difficult to assess" (www.nsdc.org, Retrieved June 13, 2005).

In education, the main purpose of any professional development activity is to enhance teaching and learning, in order to improve student achievement. Examples of questions that educators, evaluators, and researchers keep asking are: How do we know that a professional development program is impacting student achievement? How do we know that a specific training program has been effective?

The evaluation of professional development in technology is equally a complex undertaking. Killion (2002) recognizes the importance of technology in education but emphasizes that we have to know if teachers implement their knowledge and experience effectively in the classroom.

Evaluations may be carried out for various reasons, focusing on processes, results, or compliance. In current practice, most evaluations of staff development programs are carried out to comply with regulations and reporting requirements from the funding agencies. For example, evaluations may be limited to reporting on the number of training sessions, the characteristics of participants, and results of satisfaction surveys. A second type of evaluation is "process-focused" (also known as implementation or formative 
evaluation) and is based on collecting data on how the program is functioning and how the planned activities are being conducted as originally planned.

The third type of evaluation is "results-focused" (also known as impact or summative evaluation) and is concerned with answering the questions: Did the professional development program have impact? Did it produce results? Did change occur? Although changes can occur in many forms, the most important types of changes in professional development are those that affect educators' knowledge, attitudes, skills, aspirations, and behaviors. Killion (2002) defined these changes as follows: a) change in educators' knowledge is a change in the conceptual understanding of information, theories, principles, and research; b) change in attitude is a change in beliefs about the value of particular information or strategies; c) change in skills is a change in strategies and processes to apply knowledge; d) change in aspirations is a change in desires, or internal motivation, to engage in a particular practice; and d) change in behavior is a change in the application of knowledge and skills.

At the National Staff Development Council, Killion (2002) developed an evaluation framework for conducting "results-focused" evaluations. Specifically, she stated, "If the evaluator wants to answer the question about attribution, that is, did the changes occur because of the staff development program, she or he will need a comparison group who did not participate in the staff development program"(p. 82). This type of comparison may provide information about the impact of the program, and allow for conclusions about the attribution but may not provide a level of confidence in generalizations without random assignment. Killion (2002) indicated, "Comparison 
groups are perhaps the second best way to determine if a program is responsible for the intended impact" (p.88).

Comparison groups are suitable in educational settings because they do not require pure experimental design (Killion, 2002). Rossi, Freeman, \& Lispey (1999) acknowledge that conducting impact evaluation is a matter of weighing the importance of the scientific rigor against practical constraints inherent in the evaluation context.

Despite these challenges, evaluators and researchers kept conducting evaluation studies of professional development activities. Most of these evaluation studies can be characterized as post hoc studies, and can be of the following three types: pre-formative evaluation, formative evaluation, and summative evaluation (Killion, 2002). Preformative evaluation assesses initial needs during the planning process, and clarifies the intended goals of the intervention, as well as the strategies to collect the data for the evaluation (Guskey, 1996). Formative evaluation is conducted during the implementation of the professional development activity and is intended to provide feedback and recommends changes to make the activity more valuable and relevant to the needs of the participants. Summative evaluation assesses the overall merit or worth of the activity and gives decision makers the information they need to plan for the future.

Most of these studies gather their evaluation data from the participants in the form of satisfaction surveys, self-reporting questionnaires, and/or pre- and post assessment of knowledge gained from the professional development activity. They rarely involve other stakeholders who did not participate in the professional development program and therefore do not use comparison groups. The following are examples of evaluation studies of technology programs. 
The evaluation of the Preparing Tomorrow's Teachers for Technology (PT3) program at Morehead State University involved teacher education faculty who participated in the program, and assessed the impact of PT3 on the integration of technology in the regular courses taught by the participants. The content of the syllabi of the courses they were teaching were analyzed and questionnaires were used to gather data from the teacher education faculty. The unit of analysis was the course. Overall, $100 \%$ of the faculty interviewed reported integration of technology in their courses. However, a content analysis of the syllabi revealed that 15 of the courses did not mention the use of any technology (Klecher \& Lennex, 2003).

Another evaluation of the PT3 program at the same university focused on the extent to which student teachers used technology during student teaching. The study involved 110 students and included a main question "How are you infusing technology into your student teaching activities?" The study found that 36 different technologies were used: Microsoft PowerPoint and the Internet were the most used. The results revealed that $91 \%$ of the participants stated that using technology increased student learning in their classroom (Kletcher \& Hunt, 2003).

Dawson and Rakes (2003) studied the influence of the types and amounts of technology training for principals on the integration of technology into schools. Specifically, the study included 398 public and private school principals across the United States. Every state in the country was represented. The participants answered an online questionnaire that measured mainly hardware and software infrastructure. Each respondent received a composite score for the whole questionnaire as well as a score for 
each individual section of the questionnaire. The study found that the amounts and types of training significantly impacted the level of technology integration in schools.

In the case of the FloridaLeaders.net project (FLN), the Florida Department of Education conducted a summative evaluation of the project. The major question of the evaluation was "Did Floridaleaders.net, efficiently and effectively deliver technology training to school leaders?" A major portion of the evaluation was based on data gathered through self-reports in online questionnaires that were answered by participants in the program. The questionnaires asked seven questions about specific components of the FLN project. To every question, $88 \%$ to $92 \%$ of the respondents answered that the components were "very effective." The overall conclusion of the study was that an overwhelming majority of the participants was very satisfied with the project and would recommend its continuation. Specifically the study made the following recommendations: a) develop a plan to sustain Floridaleaders.net; b) incorporate the FLN project design into training of new school leaders; and c) create an "alumni" group with coordinators, trainers, and professional development partners (Cooley, 2005).

A closer look at these studies reveals that there is a need to conduct more studies on the effectiveness of professional development. Dawson (2003) reported that little research has investigated specific aspects of technology integration with regard to principal training.

Additionally, studies and evaluations that focused on the impact of professional development are limited in scope. According to Guskey (1996), a good evaluation must include at least five levels of evaluation: participants' reactions, participants' learning, 
organizational support and change, participants' use of new knowledge and skills, and student learning outcomes.

For example, the Cooley study of FLN had a variety of problems and does not provide definite conclusion and policy recommendations. These problems ranged from the fact that the sample included only participants in the project to the reliance on selfreports and the use of the participants as the main data sources. Therefore, there is a need for a new study that remedies some of these design shortcomings.

This study added new dimensions to the evaluation of the FloridaLeaders.net project. The study included a comparison group, examining the experiences of participants as well as non-participants, and used data from a larger sample size and multiple sources. Furthermore, the data-collection instruments used were based on a set of well-defined standards and indicators that can be used to gauge the level of technology integration resulting from any intervention (professional development or formal education).

Conceptual Framework for the Study

The National Staff Development Council evaluation framework was used as the conceptual framework for this study. Specifically, the "results-focused" (impact) evaluation model was used to investigate the impact of the FloridaLeaders.net project on the integration of technology in elementary schools. As discussed in the previous section, this model focuses on determining whether the professional development program produced change in educators' knowledge, attitudes, skills, aspirations, and behaviors. This study investigated impact/change on three areas of technology use: a) management and operations, b) teaching and learning, c) assessment and evaluation. 
The Technology Standards for School Administrators (TSSA) were used to measure the degree of technology presence and implementation at the FLN and non-FLN schools. These standards were defined by experts in educational technology from professional organizations, including, the International Society for Technology in Education, the National Association of School Principals, the American Association of School Administrators, the National School Board Association, and several state departments of education and universities.

These national technology standards define what school administrators should know and do to effectively integrate technology in their schools. Specifically, these standards define performance indicators and role-specific technology leadership tasks for school administrators (see Appendix A). The six standards are: a) leadership and vision, b) learning and teaching, c) productivity and professional practice, d) support, management, and operations, e) assessment and evaluation, and f) social, legal, and ethical issues. Each standard is then subdivided into four to six performance indicators. Each performance indicator contains two to three role-specific technology leadership tasks. For example, what specific tasks can the principal do to lead instructional staff members to better integrate technology into the curriculum or what can the principal do to provide teachers and staff with up-to-date technology infrastructure.

Furthermore, the National Educational Technology Standards for Teachers were partially used to assess how teachers are using technology in their schools. These standards provide examples for teachers on how to effectively use technology to improve students learning. 


\section{Summary}

This chapter presented a review of selected literature on educational technology, the role of the school administrator, the need for professional development for educators, and the need to measure the impact of professional development programs. The subsections included brief discussions of the crucial topics, identified by the Technology in Schools Task Force, in the effective use of technology in educational institutions. Specifically, these topics were: development and implementation of a school technology plan; financing and budgeting for technology programs; technology equipment and infrastructure; software applications; technology maintenance and support programs; professional development for teachers and staff; and technology integration into the curriculum and measurement of its impact on student achievement. Finally a conceptual framework for this study was presented. 
CHAPTER III

\section{METHODS}

This chapter presents a description of the participants, the instruments, the data collection procedure, the research design, and the variables used to answer the research questions.

\section{Background}

The Florida Department of Education (FLDOE), in collaboration with the Florida Technology Trainer Enhancement Center, the regional Area Centers for Educational Enhancement, and the South Florida Annenberg Challenge implemented a three-year leadership and technology development program for school leaders throughout Florida: The FloridaLeaders.net project (FLN). The Bill and Melinda Gates Foundation funded the project. The project was implemented in the six geographic areas identified by the Florida Department of Education: North East Florida, The Florida Panhandle, West Central Florida, East Central Florida, South Florida, and Miami-Dade County. This study will investigate the effect of the FLN project in Miami-Dade. The project delivery model consisted of three components:

\section{Training of Trainers}

FloridaLeaders.net identified 20 master trainers in each of the six geographic regions of the State to deliver technology training to principals. These master trainers were trained previously in technology and received additional training specific to this project. The project created a coordinator at each region to coordinate the activities of the FloridaLeaders.net project. Furthermore, the project facilitated peer interaction among 
principals to work together and discuss challenges and opportunities to integrate technology.

\section{One-on-one Professional Partnering}

FLN identified a total of 60 retired school administrators who served as part-time Professional Partners for principals. An important aspect of the FloridaLeaders.net professional development model was the use of a "one-on-one mentoring" strategy. After receiving intensive training in mentoring skills, leadership and especially technology integration these retired school principals, provided professional mentoring at the school site for in-service principals. This mentoring component gave credibility to the professional development model and benefited current principals by providing a mentor who not only knew the profession but also had acquired extensive knowledge in technology and its potential application in the educational setting.

\section{Electronic Support}

FLN created, maintained and promoted a virtual statewide network of school leaders sharing strategies, resources and solutions aimed at enhancing student achievement in all Florida schools. Furthermore, the project required the participants to do hands-on applications of technology during the intensive three-day professional development as well as during the web-based, follow-up sessions. Each principal received a state-of-the-art lap top computer and an internet-ready palm pilot, for personal and professional use.

\section{Research Questions}

The primary goal of this study is to evaluate the impact of the FloridaLeaders.net project on the integration of technology in elementary schools. The main research 
question is: Has the FloridaLeaders.net professional development model been effective in integrating technology in elementary public schools?

In order to answer the main question, three subsidiary questions were asked:

1. What is the difference in technology use in management and operations between schools whose principals participated in the FloridaLeaders.net and those who did not participate?

2. What is the difference in the use of technology in the learning and teaching environment (classrooms) in schools whose principals participated in the FloridaLeaders.net and those who did not participate?

3. What is the difference in the use of technology in the assessment and evaluation of students' learning in schools whose principals participated in the FloridaLeaders.net and those who did not participate?

Setting of the Study

The study was conducted in the fourth largest school district in the United States: The Miami-Dade County Public Schools (M-DCPS). M-DCPS is a sprawling urban system of more than 369,000 students and over 375 schools and centers (199 elementary, 7 K-8 Centers, 54 Middle, 33 Senior High schools, and 82 Alternative, Charter, Pre-K, Adult, and Specialized Education Centers). The K-12 student population is composed of a large proportion of minority with high level of poverty. Specifically, $87 \%$ of M-DCPS student population is minority (56\% Hispanic and $31 \%$ Black) and over $57 \%$ of all MDCPS schools are implementing Title I funded programs. Additionally, M-DCPS has more than 61,000 students (17\%) with limited proficiency in English who are enrolled in 
the English for Speakers of Other Languages (ESOL) program, and more than 69,000 students enrolled in Exceptional Student Education programs.

In order to control for possible contamination associated with a multitude of demographic variables such as socio-economic, English proficiency, school size, and school grade configuration (Shadish, Cook, \& Campbell, 2002), this study included only elementary schools. Furthermore, the selection of the participants in each of the three groups was done using a random process to ensure that the resulting samples are representative of the M-DCPS's populations. Tables 3.1, 3.2, and 3.3 illustrate that these samples are very similar to the populations they represent.

Selection of the Participants and Description of the Samples

The sample consisted of three groups of stakeholders: a) principals, b) media specialists, and c) teachers. Each of these three groups has a different role in the facilitation, support, and use of technology.

Principals play a major role in setting the appropriate climate by understanding what technology can and cannot do, and by setting and implementing policies for technology integration (L. Starr, Education World, 2001).

Media specialists can play a vital role in the successful implementation of technology in schools by providing principals with advice and ways on how to make use of technology as well as by providing teachers with necessary support and training on how to use technology in the classroom. Furthermore, the role of the media specialist is to ensure that students and staff are effective users, consumers, and producers of information and ideas and to provide intellectual and physical access to a wide variety of materials in all formats to all members of the school community (Media Specialist Job 
Description, Office of Human Resources, M-DCPS). The media specialists are expected to collaboratively plan with teachers to integrate technology and information literacy skills into the curriculum and design instruction so as to meet the individual needs of all learners and prepare students to meet the information and technology challenges of the 21 st century.

Teachers have a crucial role in the full development and use of technology in the schools (Office of Technology Assessment, 1995; Trotter, 1999). According to the CEO Forum on Education and Technology (1999), "The transformation of classroom technology from hardware, software, and connections into tools for teaching and learning depends on knowledgeable and enthusiastic teachers who are motivated and prepared to put technology to work on behalf of their students"(p.10).

The Principals' Sample

For the principals' group, the strategy was to randomly select elementary schools to include in the study. Following that, a letter was developed to accompany each principal's questionnaire emphasizing the voluntary participation of the principal and most importantly the confidentiality of the data provided. The self-addressed envelope did not include a return address and the questionnaire did not ask for any data that would identify the respondent.

One hundred and ten questionnaires were sent and/or given to 110 randomly selected elementary schools in M-DCPS. Of the 110 questionnaires, 47 questionnaires were completed and returned, thus a return rate of $42.7 \%$. To assess the degree of representativeness, the demographic characteristics of the sample were compared to those of the population. An examination of these demographic characteristics of the 
respondents, presented in Table 3.1, revealed that the sample was highly similar to the population of elementary schools in Miami-Dade.

Table 3.1

Demographic Comparison between the Sample and the Population of Elementary School Principals.

$\%$ of Female Principals

$\%$ of Black Principals

$\%$ of White Principals

\footnotetext{
${ }^{a}$ Source: Miami-Dade County Public Schools, District \& School Profiles 2002-2003.
}

The Media Specialists' Sample

For the Media Specialists' group, the questionnaire was sent electronically to all media specialists at all elementary schools in Miami-Dade County Public Schools. The questionnaire was developed and posted on the investigator's website using SurveyGold. As suggested by Bryman (2005), web surveys maintain greater confidentiality than emailed surveys. SurveyGold software used in this study assures the respondents of such confidentiality. An email was sent to all media specialists asking them to complete the questionnaire online. The email was not addressed individually to prospective respondents and emphasized the voluntary nature of the participation and assured the 
confidentiality of the data provided. Furthermore, there was no authentication method of verifying the identity of the person responding to the questionnaire online.

Of the 199 elementary schools, 110 media specialists answered the questionnaire online yielding a return rate of $55.7 \%$. As it can be seen in Table 3.2, most of the characteristics of the sample are representative of the District elementary schools.

Table 3.2

Demographic Comparison between the Sample and Population of Elementary Schools: Media Specialists' Respondents.

\begin{tabular}{lrc}
\hline Demographic Variable & Sample & Population $^{\text {a }}$ \\
\hline Average Number of Students in the School & 832 & 824 \\
\% of Students on Free/Reduced Price Lunch & 72.8 & 71.1 \\
\% of Limited English Proficient Students & 22.6 & 24.2 \\
$\%$ of Black Students & 28.1 & 30.0 \\
$\%$ of Hispanic Students & 60.2 & 58.0 \\
$\%$ of White Students & 9.3 & 10.0 \\
$\%$ of Media Specialists with Masters Degree & 52.3 & 41.0 \\
Average years of teaching in the District & 15.2 & 10.0 \\
\hline
\end{tabular}

${ }^{\mathrm{a}}$ Source: Miami-Dade County Public Schools, District \& School Profiles 2002-2003.

The Teachers' Sample

For the teachers' group, a questionnaire was administered to 167 elementary teachers participating in a summer professional development institute. The participants in the institute were selected by the organizers of the institute in a way that is representative 
of all elementary schools in the District based on the school geographic location (Region), socio-economic status, and academic standing (school grade).

The participants were assured of the confidentiality of their individual responses, and were informed of their option not to participate in the study. As it can be revealed in Table 3.3, most of the characteristics of the sample are similar to those of all elementary schools population in the District.

Table 3.3

Demographic Comparison between the Sample and the Population of Elementary Schools: Teachers' Respondents.

\begin{tabular}{lcc}
\hline Demographic Variable & Sample & Population $^{\text {a }}$ \\
\hline Average Number of Students in the School & 935 & 824 \\
$\%$ of Students on Free/Reduced Price Lunch & 82.0 & 71.1 \\
$\%$ of Limited English Proficient Students & 24.9 & 24.2 \\
$\%$ of Black Students & 40.3 & 30.0 \\
$\%$ of Hispanic Students & 51.7 & 58.0 \\
$\%$ of White Students & 5.8 & 10.0 \\
$\%$ of Teachers with Masters Degree & 40.0 & 41.0 \\
$\%$ of Teachers with Specialists Degree & 6.7 & 8.0 \\
Average years of teaching in the District & 10.1 & 10.0
\end{tabular}

${ }^{\mathrm{a}}$ Source: Miami-Dade County Public Schools, District \& School Profiles 2002-2003.

Instrumentation and Description of the Questionnaires

Two questionnaires were designed and validated for use in this study: one questionnaire for principals and one questionnaire for teachers and media specialists. 
The questionnaires specifically focused on measuring technology integration in schools.

\section{The Principal Questionnaire}

The principal's questionnaire was developed around the key questions that experts in the field of technology in education have determined to be central, pertaining to the type, availability, and use of technology in educational systems (Technology Standards for School Administrators, TSSA Collaborative, 2001). The TSSA task force consisted of state education agency managers, school district technology coordinators, practitioners, and leaders. The task force identified the most commonly asked, and most important, questions about technology in schools. The TSSA document presented the general framework, standards, and performance indicators that should be included when assessing technology integration in schools. To that end, a well-designed questionnaire should address the six fundamental standards presented in Figure 3.1. It should also assess the degree of implementation of typical tasks that are expected of principals who effectively lead integration of technology in their schools. The Principal's Questionnaire included the following eight sections (see Appendix B).

\section{Demographic Section}

This section included questions such as the principal's gender, ethnicity, education, and years of experience. Additionally, questions about the school's socioeconomic level, and grade configuration were also included.

\section{Vision and Leadership Section}

This section included questions such as: does the school have a technology plan? How it was developed? Does the school have a budget for technology? And what are the primary goals for using technology in the school? 
This section included questions such as: how decisions regarding technology acquisition are taken. What are the main factors that the school takes into account when purchasing hardware and software?

\section{Software Infrastructure Section}

This section included questions such as: what types of software applications are available to teachers and students? How do teachers use the software? What support is available to teachers and staff?

\section{Professional Development and Training Section}

This section included questions such as: how does the school provide technology professional development for instructional staff? and how does the school assess the training needs of faculty and staff at the school?

\section{Maintenance and Support Section}

This section included questions such as: how does the school provide technology maintenance? What is the average response time to resolve technical problems?

\section{Assessment and Evaluation Section}

This section included questions such as: how does the principal assess teachers' growth in technology? and how are teachers' efforts towards the promotion of technology assessed?

\section{Policies and Procedures of Technology Use Section}

This section included questions such as: does the school have a clear policy on the acceptable use of technology by students, teachers, and staff? How are these policies monitored? And how are these policies enforced? 


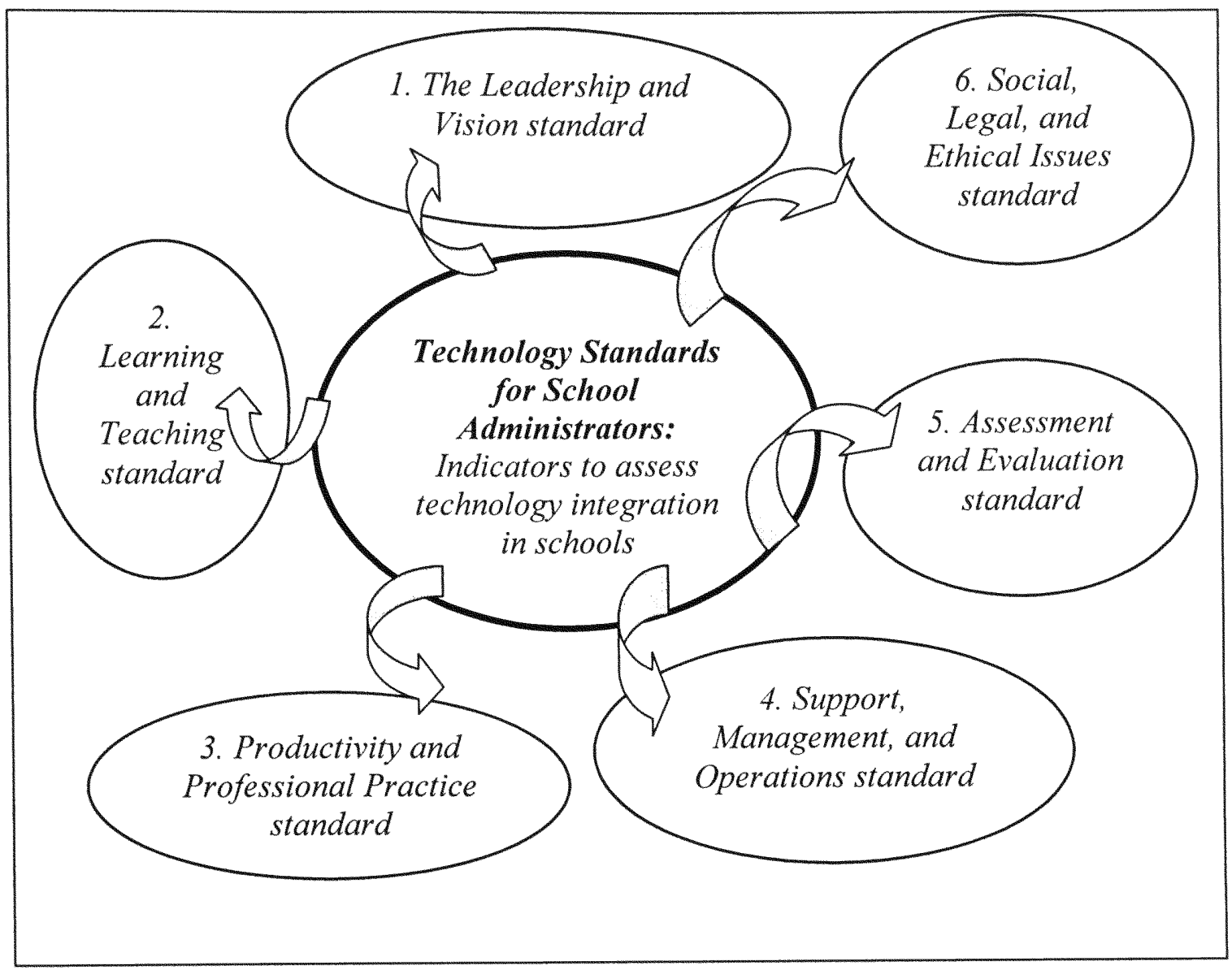

Figure 3.1. The standards and performance indicators that the Technology in Schools Task Force identified when assessing technology integration in schools.

The Media Specialists' and Teachers' Questionnaires

The media specialists and teachers' questionnaires were also developed around key questions that experts in the field of technology in education have determined to be central, pertaining to the type, availability, and use of technology in educational systems (National Educational Technology Standards for Teachers, ISTE, 2003).

The International Society for Technology in Education (ISTE) is a nonprofit professional organization with a worldwide membership of leaders in educational technology focusing on promoting appropriate use of technology to support and improve 
learning and teaching in PK-12. Although, the National Educational Technology

Standards for Teachers document included three sample instruments, they were judged not suitable for this study. These instruments focused on assessing teachers' technology knowledge, skills, and attitudes for applying technology in educational settings. Such as teachers' understanding of technology operations and concepts, teachers' ability to design learning environments using technology, and teachers' ability to develop methods and strategies to apply technology to maximize student learning.

A specific questionnaire was developed, paralleling the principal questionnaire, but from the media specialists' and teachers' perspectives. The questionnaire included the following three major sections:

\section{General Information Section}

This section included questions such as grade(s) the teacher is teaching, number of years at the current school, total number of years teaching, highest degree completed, type of computer the respondent has access to, type of software used for instructional purposes, and if the respondent has a computer in his or her classroom.

\section{Technology Infrastructure Section}

This section included questions pertaining to school technology plan, involvement of teachers in technology related decision-making, technology training for teachers, availability of modern technology hardware in the classroom, support in using and maintaining technology equipment, availability of adequate software to support learning and teaching, support in installing and using software applications. This section also included questions about the principal; such as 
does the principal model the use of technology? Does the principal use technology to communicate with teachers, parents, and students? Does the principal advocate the use of technology at the school? Does the principal involve business partners and community members in the development and enhancement of technology at the school? Does the principal enforce policies and procedures of acceptable use of technology? and does the principal monitor teachers' competency in technology and does he/she facilitate professional development in technology.

\section{Technology Use Section}

This section included questions regarding respondents' self-rating of competency, needs, and use of technology.

\section{Construction of the Questionnaires}

A literature review was conducted to identify the specific issues in relation to each of the TSSA standards, and to identify performance indicators for assessing the role of the principal in facilitating the implementation of technology in his/her school.

An initial pool of items was constructed to assess each of the six technology standards presented in Figure 3.1. Each standard included a set of items designed to serve as performance indicators of the degree of implementation of each standard. For example, in the "Leadership and Vision" standard, a set of performance indicators were included, such as: To what extent does the principal facilitate the shared development of a vision for technology use in the school, or to what extent does the principal advocate policies promoting continuous innovation with technology.

The initial items were reviewed by a group of four (three with terminal degrees) evaluation and research experts from the M-DCPS Office of Research and Evaluation. 
Three FIU professors then reviewed a revised draft of the questionnaire. During this phase, several items were deleted, and few rating scales were modified. Suggestions for additional items and improved clarity were also made during this phase.

After the initial review, 24 questions and seven demographic variables were retained. It should be noted that 20 of these questions were used to assess technology integration in the three areas mentioned previously. The instrument was reviewed a second time by a group of three recently retired principals who work part-time for MDCPS. Upon careful review, suggestions were made to clarify the wording in a few questions. Two of the measurement experts from M-DCPS Office of Research and Evaluation and two FIU professors made a final review.

Finally, at the last stage of the process a group of five recently retired principals, who work as part-timers with M-DCPS, were given the questionnaires and asked to answer them as if they were still principals at their respective schools. Three of these retired principals were elementary school principals, one was a high school principal, and one was a vocational/alternative school principal. An analysis of these responses (fieldtest) and feedback revealed that the questionnaire was clear and comprehensive. The only concern was that in some questions, the principal may not know the answer and that he/she may need the assistance of the technology coordinator or the media specialist. For example questions related to the types of software applications and the types of hardware equipment, such as network-connected computers, wireless peripherals, and projection systems. To address this concern, the letter accompanying the questionnaire was updated to inform the principals that they might request the assistance of their technology coordinators or media specialists in answering some of the technical questions. 


\section{Response Format and Scoring}

The three questionnaires (principals, teachers, and media specialists) included items that required the participants to respond using one of the following answer scales.

1. A 4-point likert-type format ranging from (Strongly Disagree) to (Strongly

Agree) that the participants used to express the level of their agreement or disagreement with the statement of the item.

2. A 4-range percentage-type format ranging from (0-25\%) to (76-100\%) that the participants used to estimate the level of presence or implementation of a certain element or behavior, such as communication with parents.

Several items on the three questionnaires were worded negatively to avoid a response set (direction). These items were then reversed to establish scale scores. All answers to the items were converted to a numerical scale with four values: 1 (strongly disagree or $0-25 \%$ ), 2 (Disagree or 26-50\%), 3 (Agree or 51-75\%), and 4 (Strongly agree or $76-100 \%$ ). Responses to individual items were averaged to create subscale scores after recoding the negatively worded items. The measures were designed to assess the varying levels of technology integration in schools. The low scores (closer to 1) reflected low integration, while high scores (closer to 4) reflected high integration of technology.

Procedures for the Administration of the Questionnaires

The researcher presented a formal request to the District to secure approval to conduct the research. For the principal group, the cover letter explained the purpose for which the questionnaire was created and were given a brief explanation of their role in the research study, along with directions on how to complete and return the questionnaire in the self-addressed envelope using regular mail. 
For the media specialists group, the questionnaire was sent electronically to all media specialists at all elementary schools in Miami-Dade County Public Schools. The questionnaire was developed and posted on the investigator's website and the request to complete the questionnaires, online, was emailed to all elementary schools as a group not individually to avoid the risk of compromising the anonymity of the respondents.

For the teachers group, the questionnaires were administered to elementary teachers participating in a summer professional development institute. The questionnaires were distributed to all participants at the end of the summer institute.

\section{Design and Procedure}

The questionnaires were designed and developed to include specific questions to answer each of the three subsidiary research questions. Specifically items measured three areas of technology utilization, paralleling the three subsidiary-research questions: a) use of technology in management and operations, b) use of technology in teaching and learning environment, and c) use of technology for assessment and evaluation. Table 3.4 lists the three areas of technology utilization, and the number of items pertaining to each area in each of the three questionnaires.

From these items, sets of subscales were constructed. In order to assess the degree to which these subscales represent the theoretical structure, a factorial validity was performed. Anastasi \& Urbina (1997) indicated that factorial validity is considered a good approach to determine the construct validity of measures. To that end, an exploratory factor analysis was performed to determine the factorial validity of the instruments measuring each of the three areas of technology integration. For each area, a 
Principal Component Analysis with a Varimax rotation was performed on each set of items from the principals, the teachers, and the media specialists' questionnaires.

Table 3.4

Number of Items Measuring Each Area of Technology Use in Each of the Three Questionnaires: The Principal, the Teachers, and the Media Specialists.

Number of Questionnaire Items

Area of Technology Use

Principals Teachers Media Specialists

Management and Operations

6

7

7

Learning and Teaching Environment

10

9

9

Assessment and Evaluation

4

3

3

\section{Variables}

As mentioned earlier, to answer the research question regarding the effectiveness of the Florida Leaders.net project on the level of technology integration, three areas of technology usage were investigated: a) use of technology in management and operations, b) use of technology in teaching and learning environment (classrooms), and c) use of technology for assessment and evaluation. In each of these three areas a set of items was developed and included in the questionnaires constructed and administered to participants in this study. Then from this set of items, a reduced set of technology indicators (dimensions) was generated and used for the analysis of the data gathered for this study. Use of Technology in Management and Operations

In this area, the degree to which the school integrates technology to support productive systems for management and operations was assessed. Assessment indicators 
included: The availability of commonly used up-to-date hardware resources, the availability of commonly used up-to-date software programs, the level of use of technology systems to manage the operations of the school, and the level of technology use at the classroom level to prepare lessons and/or manage students' records.

Table 3.5 lists the seven items representing one technology dimension (subscale) measuring the use of technology for management and operations in the principals' questionnaire. For all subsequent analyses, the responses to the seven items were averaged to create an overall indicator of technology utilization in this area. Table 3.5

Factor Structure of Technology Use for Management and Operations (TMO): Principals' Questionnaire.

Subscale

Principal's Reports on the Use of TMO

Principal's use of technology for communication.

Principal's use of technology for administration.

Teachers' use of technology for management tasks.

Teachers' use technology for communication.

Teachers' training needs in the use of technology.

Teachers' use of technology for record keeping.
.719

.823

.579

.858

.532

.514
.528

.807

.745

.83

.265

Note: To simplify readability in tables 3.5 through 3.13 , only factor loadings higher than .40 have been reported in this document.

Table 3.6 indicates that in the teachers' questionnaire, the items represented two technology dimensions: a) Teachers' self-reports of the use of technology in management 
and operations, and b) Teachers' reports of their principals' use of technology in management and operations.

Table 3.6

Factor Structure of Technology Use for Management and Operations (TMO): Teachers' Questionnaire.

\begin{tabular}{lrrr}
\hline Subscales & \multicolumn{2}{c}{ Factor Loadings } \\
\cline { 2 - 3 } & \multicolumn{2}{c}{$h^{2}$} \\
\hline Teachers' Self-Reports on the Use of TMO & & & \\
Administration and management tasks. & .869 & .755 \\
Communication with students and/or parents. & .869 & .773 \\
Technology professional development. & .412 & .210 \\
Teachers' Reports on Principals' Use of TMO & & .877 & .770 \\
Presentations to teachers. & .876 & .768 \\
Communication with teachers. & & \\
Management of personnel and student records. & .740 & .626 \\
Monitoring of teachers' technology competency. & .766 & .619 \\
\hline
\end{tabular}

An examination of Table 3.7 indicates that among the media specialists, the items represented two technology dimensions: a) Media specialists' reports on teachers' use of technology in management and operations, and b) Media specialists' reports on their principals' use of technology in management and operations. 


\section{Table 3.7}

Factor Structure of Technology Use for Management and Operations (TMO): Media Specialist's Questionnaire.

Subscales

$\frac{\text { Factor Loadings }}{1} h^{2}$

Media Specialists' Reports on Teachers' Use of TMO

Administration and management in the classroom.

Communication with students and/or parents.

Need for technology professional development.

Media Specialists' Reports on Principals' Use of TMO

Presentations to teachers.

Communication with teachers.

Management of personnel and student records.

Monitoring of teachers' technology competency.

Use of Technology in the Learning and Teaching Environment

In this area, the degree to which the school ensures that curricular design and instructional strategies integrate appropriate technologies to maximize learning and teaching was assessed. To evaluate the use of technology in this area, participating principals were asked 10 questions, and participating teachers and media specialists were asked 9 questions. Table 3.8 indicates that among the principals, the items measured two technology dimensions: a) Principals' goals and vision for using technology in learning 
and teaching, and b) Principals' report on teachers' types of use of technology in teaching and learning.

Table 3.8

Factor Structure of Technology in Learning and Teaching (TLT): Principals' Questionnaire.

Subscales

$\frac{\text { Factor Loadings }}{1} \quad h^{2}$

Principals' Reports of Goals and Vision of TLT Use

Provide instruction to students.

.614

.612

Support students' success through proven teaching and learning principles.

Promote higher order of teaching.

Promote collaborative learning in the classroom.

Create authentic learning environment.

Principals' Reports on Teachers' Use of TLT

Develop curriculum and lesson planning.

Deliver instruction.

Promote individualized instruction.

Promote heterogeneous grouping of students.

Promote interdisciplinary activities.

Table 3.9 indicates that among the teachers, the items measured two technology dimensions: a) Teachers' report on the schools' technology support and infrastructure, 
and b) Teachers' self-report on their use of technology in the teaching and learning (classroom).

Table 3.9

Factor Structure of Technology Use in Learning and Teaching (TLT): Teachers' Questionnaire.

Subscales

\section{Factor Loadings}

$\frac{1}{1} \quad h^{2}$

Teachers' Reports of the Schools' Technology Support and Infrastructure

Adequate technology training for teachers.

.834

.715

Training for teachers on technology integration.

.865

.754

Technology professional development for staff.

.758

Adequate technology equipment in the classroom.

Adequate software in the classroom.

.786

.682

Teachers' Self-Reports on the Use of TLT in the Classroom

To deliver instruction.

To promote collaborative learning.

To create authentic learning environment.

To teach about technology.

Table 3.10 indicates that among the media specialists, the items measured two technology dimensions: a) Media Specialists' report on the schools technology support and infrastructure, and b) Media Specialists' report on teachers' use of technology in the classroom. 
Table 3.10

Factor Structure of Technology Use in Learning and Teaching (TLT): Media Specialists' Questionnaire.

Subscales

Factor Loadings

$\begin{array}{ll}1 & 2\end{array}$

Media Specialists' Report on the Schools' Technology Support and Infrastructure

Adequate technology training for teachers.

.896

Training for teachers on technology integration.

.830

Technology professional development for staff.

.899

Adequate technology equipment in the classroom.

.860

Adequate software in the classroom.

.875

.682

Media Specialist's Report on Teachers' Use of TLT in the Classroom

To deliver instruction.

To promote collaborative learning.

To create authentic learning environment.

To teach about technology.

\section{Use of Technology in the Assessment and Evaluation}

In this area, the degree to which the school uses technology to access, analyze, and interpret data to focus efforts for improving student learning and productivity, was assessed. For example, the use of technology to collect, analyze, and interpret student data to improve teaching and learning, the use of evaluation results to recommend and facilitate quality professional development for faculty and staff, the assessment of staff 
knowledge in technology, and the use of evaluation results to provide quality professional development for faculty and staff. To evaluate the use of technology in this area, participating principals were asked four questions, and participating teachers and media specialists were asked three questions.

Table 3.11 indicates that among the principals, the instrument measured two technology dimensions: a) Principals' use of technology in assessment and evaluation, and b) Teachers' use of technology for assessment and evaluation.

An examination of the results of the factor analysis, presented in Table 3.12, indicates that among the teachers, the items represented only one technology dimension, Teachers' report on the utilization of technology in assessment and evaluation.

Table 3.13 shows that among the media specialists, the items represented only one technology dimension, Media specialists' reports on the use of technology in assessment and evaluation.

Table 3.14 summarizes all the technology indicators (subscales) used to measure the three technology areas in each of the three groups of participants: principals, teachers, and media specialists. 
Table 3.11

Factor Structure of Technology Use in Assessment and Evaluation (TAE): Principals' Questionnaire.

Subscales

$\frac{\text { Factor Loadings }}{1} \quad h^{2}$

Principals' Self Reports on the Use of TAE

Assess teachers' use of technology in the classroom. $\quad .920$

Assess teachers' knowledge growth in technology.

.922

Principals' Reports on Teachers' Use of TAE

Analyze students' data.

Need for technology professional development.

Factor Structure of Technology Use in Assessment and Evaluation of Students' Learning (TAE): Teachers' Questionnaire.

Subscale

Loading $h^{2}$

Teachers' Reports on the use of TAE

Principal's monitoring of teachers' technology knowledge.

$.875 \quad .765$

Principal's commitment to teachers training in technology.

$.499 \quad .766$

Teachers' use of technology to collect and analyze data.

$.391 \quad .249$ 
Table 3.13

Factor Structure of Technology Use in Assessment and Evaluation of Students' Learning (TAE): Media Specialists' Questionnaire.

\begin{tabular}{lrc}
\hline Subscale & Loading & $h^{2}$ \\
\hline Media Specialists' Reports on the Use of TAE & & \\
$\begin{array}{l}\text { Principals' monitoring of teachers' technology competency. } \\
\text { Principal's commitment to teachers' technology training. }\end{array}$ & .904 & .817 \\
$\begin{array}{l}\text { Teachers' use of technology to analyze student data. } \\
\text { T. }\end{array}$ & .498 & .180
\end{tabular}

\section{Design}

This study uses a Causal-Comparative design. The FloridaLeaders.net professional development program already took place before this study started. Therefore, it is an ex post facto (after the fact) study, and the purpose of this study is to investigate the effect of the FLN project in retrospect (Shadish \& Campbell, 2002).

In order to answer the main research question, and the three subsidiary research questions, Multivariate Analysis of Variance (MANOVA) was conducted on dependent variables obtained from the principals, the teachers, and the media specialists. The MANOVA was used to find out the main and interaction effects of categorical variables (FLN and Non-FLN) on multiple dependent variables (technology indicators or subscales). As Bray (1985) explained, MANOVA tests the differences in the centroid (vector) of means of the multiple dependent variables, for various categories of the independent variable(s). 
Table 3.14

List of Subscales (technology dimensions) Measuring the TMO, TLT, and TAE in Each of the three Questionnaires: Principals, Teachers, and Media Specialists.

Use of Technology in Use of Technology in

Management and

Operation (TMO)
Learning and Teaching (TLT)
Use of Technology in

Assessment and

Evaluation (TAE)

Principals

$\begin{array}{lll}\text { Principal's Reports } & \text { Principals'Reports } & \text { Principals'Self } \\ \text { on the Use of TMO } & \text { of Goals and Vision } & \text { Reports on the Use of } \\ & \text { of TLT Use } & \text { TAE }\end{array}$

Questionnaire

\section{Principals' Reports on Teachers' Use of TLT}

Teachers' Reports

of the Schools'

Technology

Teachers

Questionnaire

$$
\begin{aligned}
& \text { Teachers' Self- } \\
& \text { Reports of TMO Use }
\end{aligned}
$$

Support and

Teachers' Reports on

Principals' Use of

TMO

Teachers'

Self-Reports

of TLT Use in the
Classroom.

Media Specialists' Media Specialists'

Reports on Teachers' Reports on the

Use of TMO

Media

Specialists

Questionnaire

Media Specialists

Reports on

Principals' Use of

TMO
Schools'

Technology

Infrastructure

Media Specialist's

Report on Teachers'

Use of TLT in the

Classroom
Principals' Reports on Teachers' Use of TAE
Teachers' Reports

on the Use of TAE 


\section{Summary}

The purpose of this chapter was to present the methods and procedures used for this study. The research design, participants, instrumentation and setting of the study were described. Additionally, pertinent data collection and analysis procedures were outlined. The results will be presented separately for each of the three areas investigated in this study: a) Use of Technology in Management and Operations, b) Use of Technology in Learning and Teaching, and c) Use of Technology in Assessment and Evaluation. 


\section{CHAPTER IV}

\section{ANALYSIS OF DATA AND FINDINGS}

This chapter presents the results of the statistical analyses conducted to answer the main research question and the three subsidiary questions as illustrated in Figure 4.1.

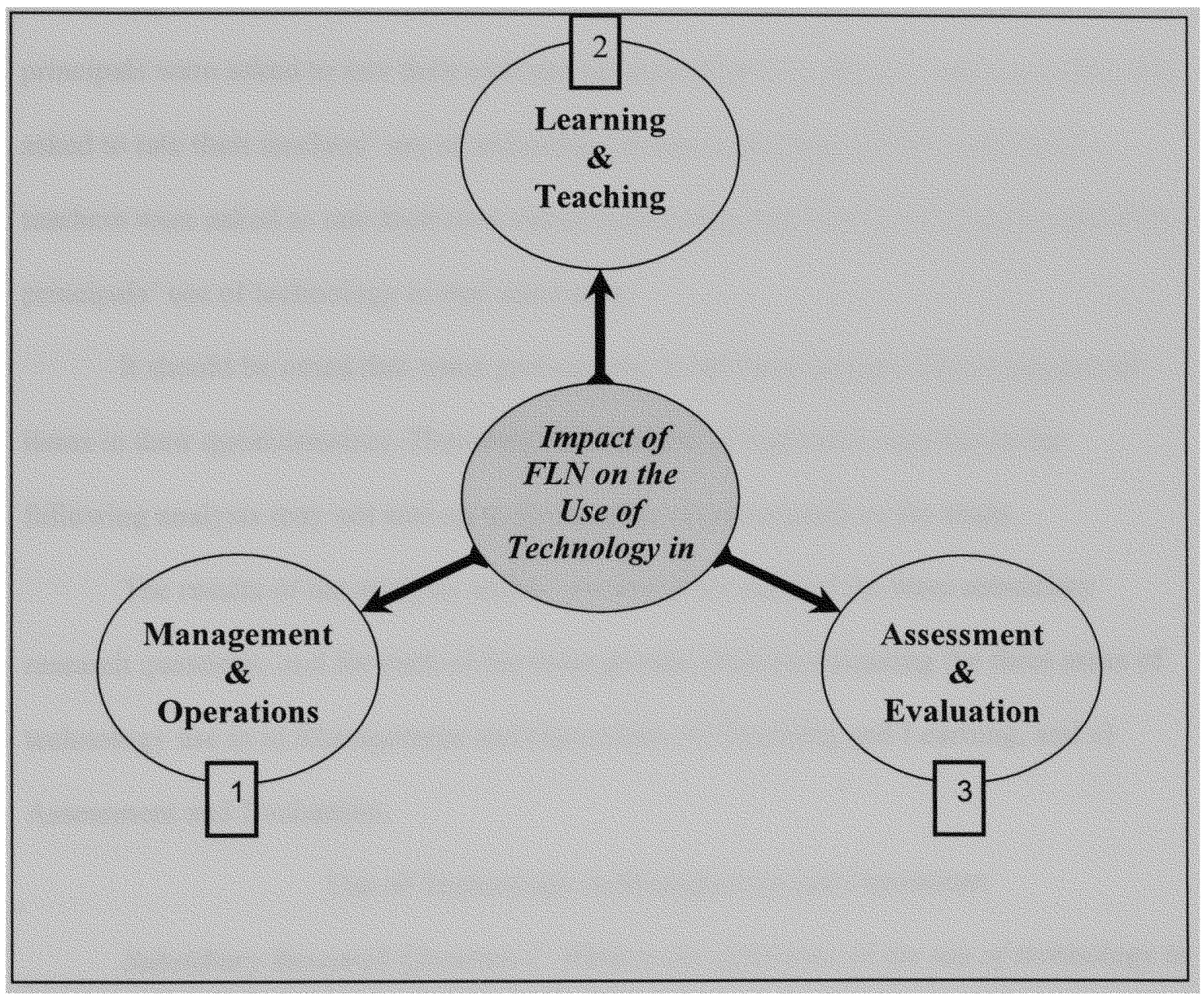

Figure 4.1. Areas of technology use that were investigated to assess the impact of FloridaLeaders.net on the integration of technology in schools.

Specifically, the main research question was: Has the Floridaleaders. Net program been effective in integrating technology in public elementary schools? 
The participants in this study were principals, classroom teachers, and media specialists. Each group of participants completed a specific questionnaire measuring various aspects of technology utilization across the school.

All participants were asked questions to assess their own use and attitudes toward technology and were also asked to assess others (self and peer-reporting). For example, principals were asked to rate their own use of technology in a specific area, and were also asked to rate their teachers' use of technology in the same area. On the other hand, teachers were asked to rate their own use of technology, and also were asked to rate their principals' use of technology in that same area.

It should be noted that some participants, in all three groups, did not answer all items in their questionnaires. Therefore the numbers of responses reported in the following analysis may not add-up to the number of participants in the study.

The results of the analysis will be presented for each of the three subsidiary research questions, and for each of the three groups, thus investigating the three areas of technology use in a) Management and Operations, b) Teaching and Learning, and c) Assessment and Evaluation.

Use of Technology in Management and Operations

Subsidiary Research Question 1: What is the difference in the use of technology in management and operations between schools whose principals participated in the FloridaLeaders.net and those who did not participate?

The purpose of this question was to assess the degree to which the school integrates technology to support productive management and operations systems, allocate financial and human resources, and develop a plan to improve technology infrastructure. 
Principals

In the principals' questionnaire, principals were asked six questions pertaining to the use of technology in management and operations, such as the use of electronic grade books, the use of technology to prepare lesson plans, and to maintain students' academic and contact records.

Responses to these six items were averaged to create an overall score representing staff and faculty use of technology for management and operations. Means and standard deviations of that overall score, in each group, are presented in Table 4.1. A one-way ANOVA comparing FLN and non-FLN groups of principals revealed that there was no significant difference between principals who participated in the FLN project and principals who did not participate in the FLN project, $F(1,40)=.049, p>.05$.

Table 4.1

Use of Technology in Management and Operations: Principals' Reports.

\begin{tabular}{|c|c|c|c|c|c|c|}
\hline \multirow[t]{2}{*}{ Subscale } & \multicolumn{3}{|c|}{ FLN Principals } & \multicolumn{3}{|c|}{$\begin{array}{l}\text { Non FLN } \\
\text { Principals }\end{array}$} \\
\hline & $n$ & $M$ & $S D$ & $n$ & $M$ & $S D$ \\
\hline Principals' reports of technology use & 28 & 2.77 & .65 & 14 & 2.73 & .57 \\
\hline
\end{tabular}

\section{Teachers}

Teachers were asked seven items pertaining to their use of technology in management and operations. From these seven items, two technology dimensions (subscales) were constructed by averaging pertinent items. 
For the first subscale (teachers' use of technology in management and operations), the means and standard deviations were $(M=1.99, S D=.74)$ for teachers whose principals participated in the FLN project and $(M=2.14, S D=.89)$ for teachers whose principals did not participate in the FLN project.

For the second subscale (principals' use of technology in management and operations), the means and standard deviations were $(M=3.05, S D=.73)$ for teachers whose principals participated in the FLN project and $(M=2.83, S D=.76)$ for teachers whose principals did not participate in the FLN project.

A one-way MANOVA with the two subscales as dependent variables indicated that there was no statistically significant difference between teachers whose principals participated in the FLN project and teachers whose principals did not participate in the project, $F(2,128)=2.80, p>.05$.

Table 4.2

Use of Technology in Management and Operations: Teachers' Reports.

\begin{tabular}{|c|c|c|c|c|c|c|}
\hline \multirow{2}{*}{ Subscale } & \multicolumn{3}{|c|}{ FLN Schools } & \multicolumn{3}{|c|}{ Non FLN Schools } \\
\hline & $n$ & $M$ & $S D$ & $n$ & $M$ & $S D$ \\
\hline $\begin{array}{l}\text { Reports of principals' use of } \\
\text { technology in management and } \\
\text { operations. }\end{array}$ & 67 & 3.05 & .73 & 64 & 2.83 & .76 \\
\hline $\begin{array}{l}\text { Self-reports of use of technology } \\
\text { in management and operations. }\end{array}$ & 67 & 1.99 & .74 & 64 & 2.14 & .89 \\
\hline
\end{tabular}




\section{Media Specialists}

Media specialists were also asked seven questions pertaining to the use of technology in management and operations. From these seven items, two technology dimensions (subscales) were constructed.

The first subscale measured media specialists' reports of teachers' utilization of technology in management and operations. The means and standard deviations for this subscale were $(M=2.32, S D=.84)$ for media specialists whose principals participated in the FLN project and $(M=2.07, S D=.95)$ for media specialists whose principals did not participate in the FLN project.

The second technology dimension assessed media specialists' reports of their principals' utilization of technology in management and operations. The means and standard deviations for this subscale were $(M=2.84, S D=.72)$ for media specialists whose principals participated in the FLN project, and $(M=2.78, S D=.75)$ for media specialists whose principals did not participate in the FLN project.

Table 4.3

Use of Technology in Management and Operations: Media Specialists' Reports.

\begin{tabular}{llllllllll}
\hline \multirow{2}{*}{ Subscale } & \multicolumn{3}{c}{ FLN Schools } & & \multicolumn{3}{c}{ Non FLN Schools } \\
\cline { 2 - 3 } \cline { 7 - 9 } & $n$ & $M$ & $S D$ & & $n$ & $M$ & $S D$ \\
\hline $\begin{array}{l}\text { Teachers' use of technology in } \\
\text { management and operations. }\end{array}$ & 67 & 2.84 & .72 & & 38 & 2.78 & .75 \\
$\begin{array}{l}\text { Principals' use of technology in } \\
\text { management and operations. }\end{array}$ & 67 & 2.32 & .84 & & 38 & 2.07 & .95 \\
\hline
\end{tabular}


A one-way MANOVA with the two subscale scores as dependent variables revealed no statistically significant difference between the two groups in the use of technology for management and operations, $F(2,102)=1.00, p>.05$.

Use of Technology in Learning and Teaching

Subsidiary Research Question 2: What is the difference in the use of technology in the learning and teaching environment (classrooms) between schools whose principals participated in the FloridaLeaders.net and those who did not participate?

The purpose of this question is to assess the degree to which the school ensures that curricular design, and instructional strategies integrate appropriate technologies to maximize learning and teaching. For example, the use of appropriate technologies to enhance and support instruction, the use of technology to meet the individual and diverse needs of all learners, the use of technology to promote high level of thinking and problem solving skills for all students, and the support for faculty and staff to participate in quality professional development and learning opportunities.

\section{Principals}

Principals were asked ten questions pertaining to the use of technology in the learning and teaching environment. From these ten items two technology dimensions were constructed by averaging each participant's responses to pertinent items.

The first subscale measured principals' goals and vision for using technology in learning, and teaching. The means and standard deviations for this subscale were $(M=$ $3.27, S D=.45)$ for principals who participated in the FLN project and $(M=3.12, S D=$ .78) for principals who did not participate in the FLN project. 
The second subscale measured principals' report on teachers' use of technology in teaching and learning". The means and standard deviations for this subscale were ( $M=$ $2.56, S D=.64)$ for principals who in the FLN project, and $(M=2.35, S D=.37)$ for principals who did not participate in the FLN project.

A one-way MANOVA with these two subscale scores as dependent variables indicated that there was no statistically significant difference between the two groups of principals, $F(2,38)=.901, p>.05$.

Table 4.4

Use of Technology in Learning and Teaching: Principals' Reports.

\begin{tabular}{|c|c|c|c|c|c|c|}
\hline \multirow[t]{2}{*}{ Subscale } & \multicolumn{3}{|c|}{ FLN Schools } & \multicolumn{3}{|c|}{$\begin{array}{l}\text { Non FLN } \\
\text { Schools }\end{array}$} \\
\hline & $n$ & $\bar{M}$ & $S D$ & $n$ & $M$ & $S D$ \\
\hline $\begin{array}{l}\text { Goals and vision for using technology in } \\
\text { learning, and teaching. }\end{array}$ & 27 & 3.27 & .45 & 14 & 3.12 & .78 \\
\hline $\begin{array}{l}\text { Teachers' use of technology in teaching } \\
\text { and learning. }\end{array}$ & 27 & 2.56 & .64 & 14 & 2.35 & .37 \\
\hline
\end{tabular}

Teachers

Teachers were asked nine questions pertaining to the use of technology in the learning and teaching environment. From these nine items, two technology dimensions were constructed.

The first subscale was an indicator of the school's technology infrastructure and support and was constructed by averaging responses to five items. The means and standard deviations of this subscale were $(M=3.05, S D=.73)$ for teachers whose 
principals participated in the FLN project and $(M=2.90, S D=.69)$ for teachers whose principals did not participate in the FLN project.

The second subscale measured teachers' report of their own use of technology and was constructed by averaging the responses to four items. The means and standard deviations for this subscale were $(M=2.15, S D=.85)$ for teachers whose principals participated in the FLN project and $(M=2.00, S D=.91)$ for teachers whose principals did not participate in the FLN project. MANOVA with the two subscale scores as dependent variable did not show statistically significant difference between the two groups, $F(2,129)=.984, p>.05$.

Table 4.5

Use of Technology in Learning and Teaching: Teachers' Reports.

\begin{tabular}{llllllllll}
\hline \multirow{2}{*}{ Subscale } & \multicolumn{3}{c}{ FLN Schools } & & \multicolumn{3}{c}{ Non FLN Schools } \\
\cline { 2 - 3 } \cline { 6 - 8 } & & $n$ & $M$ & $S D$ & & $n$ & & $M$ & $S D$ \\
\hline $\begin{array}{l}\text { School technology infrastructure and } \\
\text { support. }\end{array}$ & 68 & 3.05 & .73 & & 64 & 2.90 & .69 \\
$\begin{array}{l}\text { Self use of technology in the learning } \\
\text { and teaching environment. }\end{array}$ & 68 & 2.15 & .85 & & 64 & 2.00 & .91 \\
\hline
\end{tabular}

\section{Media Specialists}

In the Media Specialists' questionnaire, media specialists were asked nine items pertaining to the use of technology in the Teaching and Learning environment. From these nine items two subscales were constructed to assess the media specialists' reported use of technology in the learning and teaching environment. The first subscale measured 
media specialists' report of the schools' technology support and infrastructure. The means and standard deviations of this subscale were $(M=3.11, S D=.65)$ for media specialists whose principals participated in the FLN project and $(M=2.69, S D=.73)$ for media specialists whose principals did not participate in the FLN project.

The second subscale indicated media specialists' report of teachers' usage of technology in the classroom. The means and standard deviations for this subscale were $(M=2.04, S D=.86)$ for media specialists whose principals participated in the FLN project and $(M=1.80, S D=.88)$ for media specialists whose principals did not participate in the FLN project.

The results of a one-way MANOVA comparing FLN and non-FLN groups revealed a significant multivariate difference, $F(2,98)=4.70, p<.02$.

Table 4.6

Use of Technology in Learning and Teaching: Media specialists' Reports.

\begin{tabular}{|c|c|c|c|c|c|c|}
\hline \multirow{2}{*}{ Subscale } & \multicolumn{3}{|c|}{ FLN Schools } & \multicolumn{3}{|c|}{ Non FLN Schools } \\
\hline & $n$ & $\bar{M}$ & $\overline{S D}$ & $n$ & $M$ & $\overline{S D}$ \\
\hline $\begin{array}{l}\text { Schools technology support, and } \\
\text { infrastructure. }\end{array}$ & 63 & 3.11 & .65 & 38 & 2.69 & .73 \\
\hline $\begin{array}{l}\text { Teachers' use of technology in the } \\
\text { classroom. }\end{array}$ & 63 & 2.04 & .86 & 38 & 1.80 & .88 \\
\hline
\end{tabular}

Following significant multivariate difference, a univariate analysis of variance was conducted on each dependent variable separately. As suggested by Tabachnick and Fidel (2003), a Bonferroni-adjusted alpha level of level .025 (.05 dived by two, the number of dependent variables in MANOVA) was used. Table 4.7 indicates that only one 
subscale (Media specialists' reports of technology support and infrastructure) revealed significant differences between FLN and non-FLN groups, $F(1,98)=4.15, p<.05$. The estimate of effect size eta squared $\left(\eta^{2}\right)$ is .005 . Media specialists whose principals participated in the FLN project reported greater technology infrastructure in their schools than their counterparts whose principals did not participate in the FLN project.

Table 4.7

ANOVA Results of the Use of Technology in Learning and Teaching: Media Specialists' Reports

\begin{tabular}{|c|c|c|c|c|c|c|}
\hline \multirow[b]{2}{*}{ Technology dimension (Subscale) } & \multicolumn{2}{|c|}{ FLN } & \multicolumn{2}{|c|}{ Non FLN } & \multirow[b]{2}{*}{$F$} & \multirow[b]{2}{*}{$p$} \\
\hline & $M$ & $S D$ & $M$ & $S D$ & & \\
\hline Schools technology infrastructure & 3.11 & .65 & 2.69 & .73 & 8.78 & $.00^{*}$ \\
\hline Media specialists use of technology & 2.04 & .86 & 1.80 & .88 & .16 & .18 \\
\hline
\end{tabular}

Technology in Assessment and Evaluation

Subsidiary Research Question 3: What is the difference in the use of technology in the assessment and evaluation of students' learning between schools whose principals participated in the FloridaLeaders.net and those who did not participate?

The purpose of this question is to assess the degree to which the school uses technology in assessment and evaluation of students' learning and teachers' growth and efforts towards the promotion of technology in the classroom.

\section{Principals}

Principals were asked four questions pertaining to the use of technology in the Assessment and Evaluation of students' learning. From these items two subscales were 
constructed. The means and standard deviations of the first subscale (principals' report of technology use in assessment and evaluation) were $(M=2.33, S D=.95)$ for principals who participated in the FLN project and $(M=2.46, S D=1.06)$ for principals who did not participate in the FLN project.

The second subscale measured principals' reports of their teachers' use of technology in the assessment and evaluation of students' learning". The means and standard deviations of this subscale were $(M=2.89, S D=.75)$ for principals who participated in the FLN project and $(M=2.78, S D=.87)$ for principals who did not participate in the FLN project.

A one-way MANOVA with the two subscales as dependent variables compared the two groups but did not reveal any significant difference, $F(2,35)=.162, p>.05$. Table 4.8

Use of Technology in Assessment and Evaluation: Principals' Reports

\begin{tabular}{|c|c|c|c|c|c|c|}
\hline \multirow[t]{2}{*}{ Subscale } & \multicolumn{3}{|c|}{ FLN Principals } & \multicolumn{3}{|c|}{$\begin{array}{l}\text { Non-FLN } \\
\text { Principals } \\
\end{array}$} \\
\hline & $n$ & $M$ & $S D$ & $n$ & $M$ & $S D$ \\
\hline $\begin{array}{l}\text { Principals' usages of technology in } \\
\text { assessment and evaluation }\end{array}$ & 24 & 2.33 & .95 & 14 & 2.46 & 1.06 \\
\hline $\begin{array}{l}\text { Principals' reports of their teachers' } \\
\text { use of technology in the assessment } \\
\text { and evaluation. }\end{array}$ & 24 & 2.89 & .75 & 14 & 2.78 & .87 \\
\hline
\end{tabular}

Teachers

Teachers were asked three questions measuring the use of technology in the assessment and evaluation of students' learning. Each teacher's responses to these items 
were averaged to obtain a single score. The means and standard deviations of this score were $(M=2.92, S D=.78)$ for teachers whose principals participated in the FLN project and $(M=2.59, S D=.72)$ for teachers whose principals did not participate in the FLN project. A one-way ANOVA indicated a statistically significant difference between the two groups, $F(1,148)=7.42, p<.05, \eta^{2}=.47$. This finding suggests that teachers whose principals participated in the FLN project used significantly more technology to assess and evaluate their students' learning.

\section{Media Specialists}

Media specialists were also asked three questions pertaining to the use of technology in the assessment and evaluation of students' learning. Responses to the three items were averaged for each media specialist, obtaining a single score. The means and standard deviations of that score were $(M=2.86, S D=.65)$ for media specialists whose principals participated in the FLN project and $(M=2.75, S D=.78)$ for media specialists whose principals did not participate in the FLN project. A one-way ANOVA did not reveal statistically significant difference between media specialists whose principals participated in the FLN projects and media specialists whose principals did not participate in the project. The results of the ANOVA indicated that there is no significant difference between the two groups, $F(1,107)=.602, p>.05$.

\section{Summary}

The main research question was to investigate the effectiveness of the FloridaLeaders.net professional development in integrating technology in elementary public schools; three areas of technology utilization were investigated. These areas were: a) the use of technology in management and operations, b) the use of technology in the 
teaching and learning environment, and c) the use of technology for assessment and evaluation. In each of these three areas, differences between FLN and non-FLN schools were examined based on principals, teachers, and media specialists' responses.

Significant differences were found in two cases.

1. In the first case, teachers whose principals participated in the FLN project reported using significantly more technology for assessment and evaluation than teachers whose principals did not participate in the FLN project.

2. In the second case, media specialists whose principals participated in the FLN project reported higher technology infrastructure in their schools than their counterparts whose principals did not attend the FLN project.

It should be noted that an inspection of the responses to the individual items (see Appendix D) in the three questionnaires revealed that all FLN and non-FLN principals, teachers, and media specialists reported the need for professional development in technology for teachers to provide them with the necessary "know-how" to effectively integrate technology into the classrooms. 


\section{CHAPTER V}

\section{DISCUSSION AND CONCLUSIONS}

This chapter presents an overview of the study, followed by a discussion of the findings and results. The discussion is presented in the context of the literature related to public policy and professional development and its impact on educational technology. The chapter concludes with recommendations for future research and policy implications of the findings.

\section{Overview of the Study}

The purpose of this study was to investigate the effectiveness of a technology professional development program for principals (FloridaLeaders.net) on integrating technology in elementary schools.

The purpose of the FloridaLeaders.net project was to enhance the skills of school administrators to enable them to effectively integrate technology into the classrooms and curricula of schools. Specifically, school administrators would be able to understand the opportunities and challenges of technology in schools, and therefore take advantage of the opportunities and overcome the challenges to effectively use technology in schools. They would be able to provide their teachers with adequate professional development experiences, and adequate infrastructure to integrate technology into the classrooms to improve teaching and learning.

The study compared a group of schools whose principals have participated in the FloridaLeaders.net program with schools whose principals have not participated in the program. The study focused on investigating the degree to which this project facilitated 
the integration of technology into the schools. The National Technology Standards for School Administrators and the National Technology Standards for Teachers were used as the framework to assess technology integration.

Three areas of technology utilization were investigated: a) the use of technology in management and operations, b) the use of technology in the teaching and learning environment, and c) the use of technology for assessment and evaluation. The specific research questions, which guided this study, are the following:

1. What was the difference in technology use in management and operation between schools whose principals participated in the FloridaLeaders.net and those who did not participate?

2. What was the difference in the use of technology in the learning and teaching environment (classrooms) in schools whose principals participated in the FloridaLeaders.net and those who did not participate?

3. What was the difference in the use of technology in the assessment and evaluation of students' learning in schools whose principals participated in the FloridaLeaders.net and those who did not participate?

The sample consisted of three groups of educators: principals, teachers, and media specialists from Miami-Dade County Public Schools. Two questionnaires were designed and validated for use in this study: one questionnaire for principals and one questionnaire for teachers and media specialists. The questionnaires focused on measuring the level of technology integration in schools and included key questions that experts in the field of technology in education have determined to be central, pertaining to the type, availability, and use of technology in educational systems. 
In each of the three areas ANOVA and/or MANOVA statistical analyses were used to examine differences between FLN and non-FLN schools in each of the three groups.

\section{Summary of Findings}

The following summarizes the finding of the study:

1. There was no significant difference between FLN and non-FLN groups in their use of technology for management and operations. Lack of differences existed in all three groups: principals, teachers, and media specialists.

2. There were no significant differences between FLN and non-FLN principals or their teachers in the use of technology in the learning and teaching environment (classrooms).

3. There was a statistically significant difference between media specialists whose principals participated in the FLN project and media specialists whose principals did not participate in the FLN project in the use of technology in the learning and teaching environment (classrooms) in their schools. Specifically, media specialists whose principals participated in the FLN project reported a higher technology infrastructure in their schools than their counterparts whose principals did not attend the FLN program.

4. There were no significant differences between FLN and non-FLN principals or their media specialists in the use of technology for assessment and evaluation.

5. There was a significant difference between teachers whose principals participated in the FLN projects and teachers whose principals did not participate 
in the project on the technology dimension representing teachers' use of technology for assessment and evaluation.

\section{Discussion of Findings}

The framework for this study was established around the assessment of the level of integration of technology through an assessment of the utilization of technology in the following three areas: a) utilization of technology for management and operation, b) utilization of technology for teaching and learning, and c) utilization of technology for assessment and evaluation.

Use of Technology in Management and Operations

Although there was no significant difference between the FLN and non-FLN principals, the following results were noted.

Principals expressed that there is a need for technology training for teachers on how to use technology to perform administrative and management tasks. Both groups of principals reported that teachers do not use enough technology in management and operation, especially in communicating with students and parents. Principals also indicated that their teachers are using technology at a moderate level in other sub-areas of management and operations, such as record keeping, and lesson planning.

For the teachers groups, although there was no significant difference between teachers whose principals participated in the FLN project and teachers whose principals did not participate in the FLN project, the following results were noted. Both groups of teachers reported that they need training in how to use technology to perform administrative and management tasks. Teachers also indicated that they are not using enough technology in management and operations, especially in communicating with 
students and parents. Teachers reported that their principals used technology to communicate with them but did not do enough to promote teachers' competence in using technology for management and operations.

For the media specialists, participants indicated also the low level of teachers' use of technology, and the need for technology training for teachers. Media specialists, however, expressed that their principals had an acceptable level of use of technologybased management systems such as accessing and maintaining personnel and student records. Unlike teachers, media specialists reported that principals are not using enough technology in front of teachers.

Use of Technology in Teaching and Learning

Although there was no significant difference between the FLN and non-FLN principals, the following results were noted.

Both groups of principals indicated that their main goal for using technology in their schools is to provide instruction to students, promote higher order thinking, and promote collaborative learning between students. This finding is consistent with many other studies in the field. For example, Dawson \& Rakes (2003) concluded that as principals understand better the potential of technology in enhancing teaching and learning and in improving student achievement, their support for teachers in integrating technology into the classroom increases.

Principals also reported that their teachers' main utilization of technology in teaching and learning was to promote individualized instruction and to promote interdisciplinary activities and real world applications. Principals, especially FLN 
principals, indicated that their teachers were not using technology to teach about technology.

Among the teachers, both FLN and non-FLN teachers indicated that their schools provided them with an adequate technology infrastructure and equipment in their classrooms. However, these same teachers reported that their schools did not provide them with adequate level of support and training, especially at non-FLN schools, to facilitate the integration of technology into the classroom. This finding is consistent with findings from the previous sections suggesting that although the hardware infrastructure is available in schools, teachers are not provided with the necessary training to effectively use technology and integrate it into the teaching and learning in their classrooms.

Teachers also reported that they used technology to deliver instruction, promote collaborative learning, and create authentic learning environment, and that they did not use technology to teach about technology. This finding is consistent with that of a study by NETDAY, a California-based non-profit group that spent five years in a technology project involving schools, principals, and teachers, and concluded that teacher knowledge and practice are the most significant outcomes of any staff development (Weiner, 2001). In other words, teachers constitute the primary factor influencing the relationship between staff development and improvement in student learning. Therefore, if staff development does not change teachers' classroom practices, then little improvement in student learning can be expected (Guskey \& Sparks, 1996).

In the Media Specialists group, two technology indicators were used to assess the use of technology for teaching and learning: a) Technology infrastructure and support of the schools, and b) Teachers' use of technology in the classroom. 
A significant multivariate difference was found between FLN and non-FLN groups. Media specialists whose principals participated in the FLN project reported higher technology infrastructure than their counterparts whose principals did not attend the FLN project. Furthermore, contrary to the finding from the teachers' group, media specialists believe that teachers have adequate access to training in technology. This could be biased and may be explained because media specialists are expected, as part of their job responsibilities at their schools, to provide support and training to regular classroom teachers on the use of technology.

Use of Technology in Assessment and Evaluation

Although there was no significant difference between the FLN and non-FLN principals, the following findings were noted.

Both groups of principals indicated that their teachers still need specific professional development in technology in order to use it in the assessment and evaluation of student learning. This finding is consistent with the principal actual rating of their teachers' use of technology in the assessment and evaluation of students learning. Furthermore, this indicates an understanding from the principals, especially FLN principals, of the value of professional development for their teachers. This finding is also supported by other studies, such as McNamara and McGillivray (1999) that indicated "... through technology training and experience, administrators develop a deeper understanding of the potential of instructional technology and become more empathetic to the anxieties of teachers who are learning to cope with the complexity of using technology in their classroom". In other words, principals will be more supportive of their teachers because they understand better their needs. 
For the teachers groups, the results indicate that there was a statistically significant difference between the two groups in reported use of technology in assessment and evaluation. Teachers whose principals participated in the FLN project used significantly more technology to assess and evaluate their students' learning. This finding is consistent with a study conducted by the International Society for Technology in Education (2003) that indicated that because of the constant push toward higher test scores and accountability, teachers are forced to find new and innovative ways of reaching all students. This finding also supports a study on the Technology Integration in Chicago Public Elementary Schools, (Hawkins et al., 1999) which indicated that strong accountability measures discourage experimentation in favor of testing the skills, drilling and memorizing using technology.

For the media specialists, both groups indicated that teachers at their schools were provided with knowledge in technology. This finding is contrary to the teachers' assessment, but consistent with the media specialist response to other items. As mentioned earlier, this could be a result of the fact that media specialists are expected, as part of their job responsibilities, to provide support and training to regular classroom teachers on the use of technology.

\section{Conclusions}

Despite the fact that the average rating of technology integration was consistently higher in FLN schools, the difference was not statistically significant in most of the technology indicators. This would indicate that FloridaLeaders.net was not effective in integrating technology in schools over and above other current efforts. However, the following additional findings emerged from both FLN and non-FLN groups. 
The need for technology training: In both FLN and non-FLN groups, all three participants (principals, teachers, and media specialists) expressed concerns about the lack of training. This finding supports Bailey (2002) assertion that education has not kept pace with other sectors in the use and the integration of technology, and that the principals' lack of vision and understanding of the potential of technology is the major obstacle to bringing schools into the information age.

The teachers also expressed that they need professional development activities that focus on how to integrate technology into their classroom. All groups including teachers themselves reported low level of teachers' use of technology.

This finding is consistent with findings from other research studies. For example, the non-profit Education Development Center conducted a nationwide study "Effective Access: Teachers' Use of Digital Resources in Teaching" and concluded that although teachers indicated that they had taken part in professional development activities, they expressed frustration about the lack of quality of technology training for teachers (www.edc.org/EffectiveAccessReport.pdf, Retrieved July 4, 2005).

Other studies (Atkins, 2000; Casey \& Rakes, 2002; Smith, 1999) also indicated that focused technology training for teachers is needed to promote the use of technology in the classroom. Carabine (1999) and (Eastwood et al., 1998) indicated that the lack of quality professional development for teacher is due to the fact that administrators have often failed to schedule and fund technology training for their teachers.

The availability of technology infrastructure: In both groups, participants indicated the availability of adequate technology infrastructure. This finding indicates that schools are acquiring adequate hardware equipment and software programs. This 
finding is consistent with the findings of a national survey of technology infrastructure (National Center for Educational Statistics, 2001), which indicated that in fall 2001, ninety-nine percent of public schools in the United States had access to the Internet, and the ratio of students to instructional computers with Internet access in public schools was 5 to 1 , an improvement from the 12 to 1 ratio in 1998.

\section{Policy Implications}

One of the explanations for a lack of difference between FLN and non-FLN group might be that technology integration in school is a complex task that requires the involvement, collaboration, and commitment of several stakeholders, especially the principals. Principals remain vital in the successful integration of technology in their schools and that the more sustained and focused training they receive, the more likely their schools will move toward technology integration (Guskey, 2002). Furthermore, technology infrastructure is not an indicator of technology integration in a school. However, combined with the "know-how to use technology" is a much more reliable measure of technology integration.

It is conceivable that FloridaLeaders.net provided infrastructure but not enough "know-how" to integrate technology especially at the classroom level. Getting the "know-how to use technology" is more difficult and more complex than acquiring the hardware or software infrastructures. Quality professional developments that are sustained and focused on each stakeholder's specific needs should be planned, developed, and implemented. School administrators must understand that teachers have the primary responsibility to integrate technology into the curriculum, and align it with student learning outcomes, and most importantly implement it in the classroom with students. 
Teachers represent the executers of any technology plan or initiatives at the classroom level. Technology hardware and software infrastructure, although necessary, is not enough.

Finally given the fact that professional development is frequently the first victim of budget cuts, it is imperative to document the impact of these intervention programs to sustain their funding. As Linda Darling-Hammond (1998) stated, "We need to deepen our understanding of what good professional development opportunities look like in different contexts, through concrete images, examples, and experiences." (www.nrel.org, Retrieved July 4, 2005). Furthermore, policy makers in the public sector, such as school boards, state departments of education, and the US Department of education, are asking superintendents and administrators to document the effectiveness of staff development efforts on the improvement of student achievement.

It is therefore recommended that administrators at local and state educational agencies look seriously at how to document and highlight the impact of their professional development activities. In the absence of such documentation, they will run the risk of losing these professional development funds and may even be required to outsource these activities to the private sector. In 1992, Scott Tannenbaum and Gary Yukl developed an extensive review of the existing corporate training literature. They found that training and staff development in the private sector had matured into a legitimate discipline that used research, theory, and informed practice. Furthermore, voices within and outside education are lauding the successes of professional development in the private sector (DarlingHammond, 1998). 
Based on the experience conducting this study and its findings, the following are some recommendation for future research.

1. As Kelly (2004) explained, the goals of professional development do not always lend themselves to quantitative or measurable evaluation. It is therefore recommended to conduct further research with built in site visits to observe teaching and learning and to inspect the presence as well as the level of utilization of the software and hardware infrastructure. Conducting focus groups with several stakeholders, especially students, teachers, and administrators to assess the type and level of their technology utilization will add value to future studies.

2. It is also recommended to investigate other elements that do influence the successful integration of technology in schools, such as the technology curriculum in the teacher preparation programs. This type of required training is more structured and has more built-in accountability (grades, and degree requirements of the program) than regular professional development. This should enhance the dialogue already in motion between K-12 and post-secondary institutions in Florida as part of the $\mathrm{k}-20$ seamless educational system. 


\section{REFERENCES}

Alhalabi, B. A., (November, 1999). Remote labs for distance education, a step beyond simulation, Centennial Computing Workshop, Lafayette, LA: CACS

Alhalabi, B. A., Anandapuram, S, Hamza, M.K., and Hsu, S., (February, 1999). Virtual education: Reality or virtuality. Society for Information Technology \& Teacher Education, Association for the Advancement of Computing in Education (AACE/SITE 99), Published Conference Paper. San Antonio, TX.

Anastasi, A , \& Urbina, S. (1997). Psychological testing ( $7^{\text {th }}$ ed.). Upper Saddle River, NJ: Prentice Hall.

Association for Educational Communications and Technology. (1977). Educational technology: Definition and glossary of terms. Washington, DC.

Atkins, N. (2000). Measuring knowledge of technology usage and stages of concerns about computing. Journal of Technology and Teacher Education.

Bailey, D., and Bailey, S. (1995, December). Aligning community: More-than-rational approaches to whole-system change. Workshop presented at a conference of the National Staff Development Council, Chicago, IL.

Bailey, J. (2002). Leadership and no child left behind. Technology \& Learning 22(11), 4.

Bryman, A. (2005). Social research methods. ( $2^{\text {nd }}$ ed.). Oxford University Press.

Byrom, E. (1998). Factors influencing the effective use of technology for teaching and learning: Lessons learned from the SEIR-TEC intensive site schools. Retrieved from http://www.serve.org/seir-tec/publications/lessons.html

Carbine, B. (1999). Creating a collaborative learning environment in classrooms. Technological Horizons in Education, 10 200-221.

Carlson, R. D. (1998). Creating technology policy: A systematic model. Paper presented at the meeting of the Society for Information Technology and Teacher Education, Washington, DC.

Casey, H. (2002). An analysis of the influences of technology training on teachers. Journal of Computing in Teacher Education, Volume 4, Number 18.

CEO Forum on Education and Technology. (1999). Professional development: A link to better learning. Retrieved from http://www.ceoforum.org/downloads/99report.pdf

Collaborative for Technology Standards for School Administrators. (2001). Technology standards for school administrators. Retrieved from http://cnets.iste.org/tssa/view_standards.html 
Cooley, F. (2005). A Summative evaluation of the FloridaLeaders.net project. Evaluation prepared for the Florida Department of Education. Tallahassee, FL

Corcoran, T.C. (1995). Transforming professional development for teachers: A guide for state policymakers. Washington, DC: National Governors' Association.

Creighton, T. B. (2002). The principal as technology leader. Thousand Oaks, CA: Corwin Press.

Darling-Hammond, L. \& Berry, B. (1998). Investing in teaching. Retrieved from http://www.edweek.org/ew/vol-17/37darlin.h17

Darling-Hammond, L. (1999). Target time toward teachers. Retrieved from http://www.nsdc.org/library/publications/jsd/darling202.cfm.

Dawson, G. (2003). Issues and directions in preparing school leaders: Lessons from a worldwide web. ACE Newsletter, Monograph no. 30, September.

Dawson, C., \& Rakes, G. (2003). The influence of principals' technology training on the integration of technology into schools. Journal of Research on Technology in Education. Eugene: Fall 2003.Vol.36.

Deal, T. (1987). The culture of schools. In L. Sheive \& M. Schoeheit (Eds.), Leadership: Examining the elusive (pp. 3-15). Alexandria, VA: ASCD.

DuFour, R. \& Eaker, R. (1998). Professional learning communities at work: Best practices for enhancing student achievement. Alexandria, VA: ASCD.

DuFour, R.P. (1997). The school as a learning organization: Recommendations for school improvement. NASSP Bulletin, 81 (588), 81-87.

Dunteman, George H. (1989). Principal components analysis. Thousand Oaks, CA: Sage Publications.

Education Commission of the States (2001). Investing in K-12 technology equipment: Strategies for state policymakers. ECS Issue Paper: Technology. Denver, CO: ECS.

Fatemi, E. (1999, September 23). Building the digital curriculum. Retrieved from http://www.edweek.org/sreports/tc99/articles/summary.htm

Fullan, M. (1994). Change forces: Probing the depths of educational reform. Bristol, PA: The Falmer Press.

Fullan, M. (2001). The new meaning of educational change (3rd ed.). New York: Teachers College Press.

Fullan, M. G. (1991). Staff development, innovation, and institutional development. ( $p p$. 3-25). Alexandria, VA:ASCD 
Gardner, H. (1993). Multiple intelligences: The theory in practice. New York, NY: Harper Collins Publishers.

Gardner, H. (2000). Can technology exploit our many ways of knowing?. In Gordon. (Ed), The digital classroom (pp 32-35). Cambridge, MA: The Harvard Education Letter.

Gay, L. R., \& Airasian, P. (2000). Educational research: Competencies for analysis and applications $\left(7^{\text {th }}\right.$ ed.). Upper Saddle River, NJ: Merrill Prentice Hall.

Gordon, D. (2000). The digital classroom: How technology is changing the way we teach and learn. Harvard Education Letter. Cambridge, MA

Gorsuch, R. L. (1983). Factor analysis. Hillsdale, NJ: Lawrence Erlbaum.

Grabe, M., \& Grabe, C. (2004). Integrating technology for meaningful learning (4th ed.). New York: Houghton Mifflin.

Grant, C. M. (2003). Professional development in a technological age: New definitions, old challenges, new resources. Retrieved from http://ra.terc.edu/publications/terc_pubs/tech-infusion/prof_dev.html

Green, S. B., Salkind, N., \& Akey, T. (2002). Using SPSS for windows: Analyzing and understanding data. Saddle Upper River, NJ: Prentice Hall.

Guhlin, M. (1996, May). Stage a well-designed Saturday session and they will come! Technology Connection, 13-14.

Guskey, T. \& Sparks, D. (1996 Fall). Exploring the relationship between staff development and improvements in student learning. Journal of Staff Development, 17(4), 34-38.

Guskey, T. (2000). Evaluating Professional development. Thousand Oaks, CA: Corwin Press.

Guskey, T. R. (1999). Enhancing the effectiveness of professional development programs. Journal of Educational and Psychological Consultation, 2(3), 239-247.

Guskey, T. R., \& Sparks, D. (1996). What to consider when evaluating staff development. Educational Leadership, 49(3), 73-76.

Guskey, T.R. (1996). Jointly planning staff training. The School Administrator, 53 (11). Retieved from http://www.nsdc.org/library/publications/jsd/guskey202.cfm.

Guskey, T.R. (2003). Analyzing lists of the characteristics of effective professional development to promote visionary leadership. NASSP Bulletin, 87 (637), 4-20.

Hall, G. \& Hard, S. (1987). Change in schools: Facilitating the process. Albany, NY: University of New York Press. 
Hall, G. \& Hard, S. (2001). Implementing change: Patterns, principles, and potholes. Albany, NY: State University of New York Press.

Hall, G. \& Loucks, S. (1979). Implementing innovations in schools: A concerns-based approach. Austin, TX: Research and Development Center for Teacher Education, University of Texas.

Hall, G. E., \& Loucks, S.F. (1978). Teacher concerns as a basis for facilitating and personalizing staff development. Teachers College Record, 80, 36-53.

Hallam, S. (1998). Misconduct on the information highway: abuse and misuse of the internet. Ethics, information and technology readings. Stichler, R. N. and Hauptman, R. editors. Jefferson, NC: McFarland and Company, Inc., Publishers.

Hamza, M. K., \& Checker, C. (February, 2000). Learning creatively: One professor's enormous challenge - Any Takers? Society for Information Technology \& Teacher Education (SITE) 2000, Published Conference Paper. San Diego, CA.

Hand, D.J. and C. C. Taylor (1987). Multivariate analysis of variance and repeated measures. London: Chapman and Hall.

Harmon, H. H. (1967). Modern factor analysis. (2nd ed). Chicago: University of Chicago Press.

Hinkle, D. E., Wiersma, W., \& Jurs, S. G. (1998). Applied statistics for the behavioral sciences. New York: Houghton Mifflin.

Hirsch, E.D. (1996). The schools we need and why we don't have them. New York, NY: Doubleday.

Hope, W. C., Kelley, B., \& Guyden, J. A. (2000, February). Technology standards for school administrators: Implications for administrator preparation programs. Paper presented at the annual conference of the Society for Information Technology and Teacher Education, San Diego, CA.

International Society for Technology in Education. (n.d.). Recommended foundations in technology for all teachers. Retrieved from http://www.iste.org/Standards

Jae-On, K. \& Mueller, C. (1978b). Factor analysis: Statistical methods and practical issues. Thousand Oaks, CA: Sage Publications.

Jones, B. F., et al. (1995). Plugging in: Choosing and using educational technology. Washington, DC: Council for Educational Development and Research. Retrieved from http://www.ncrel.org/sdrs/edtalk/toc.htm

Kauffman, D. \& Khalid, H. (1998). Educational reform: Ten ideas for change, plus or minus two. Paper presented at the meeting of the Society for Information Technology and Teacher Education, Washington, DC. 
Kelly, C. (2004). Evaluating a staff development program. Retrieved from http://www.askasia.org/for_educators/professional_development_grants/ teach_asia_initiative/handbook/Kelly.htm

Kelley, C., \& Peterson, K. (2000). Principal inservice programs: A portrait of diversity and promise. Paper prepared for the National Center on Education and the Economy and the Carnegie Foundation.

Killion, J (2002), Assessing impact: Evaluating staff development. Oxford, OH: National Staff Development Council.

Killion, J. (1998). Leaders have key role in promoting staff development. Retrieved from http://www.nsdc.org/library/publications/results/res10-98killion.cfm.

Killion, J. (1999). Design staff development with student needs in mind. Retrieved from http://www.nsdc.org/library/publications/results/res4-99killion.cfm.

Killion, J. (1999). What works in the middle: Results-based staff development. Oxford, $\mathrm{OH}$ : National Staff Development Council.

Killion, J. (November 1999). Forge a link between adult learning and student learning. Results. Oxford, OH: National Staff Development Council.

Kirkpatrick, D. (1998) Evaluating training programs: The four levels. (2nd ed.). San Franscisco: Berret-Kohler Publishers.

Kleiman, G. (2000). Myths and realities about technology in K-12 schools. In Gordon. (Ed), The digital classroom (pp 7-15). Cambridge, MA: The Harvard Education Letter.

Kosakowski, J. (1998). The benefits of information technology. Retrieved from http://www.eric.ed.gov/contentdelivery/servlet

Kuperstein, J., Gentile, C., \& Zwier, J. (1999). The connected learning community technology roadmap. Retrieved from http://www.microsoft.com/Education/vision/roadmap/default.asp

Lawley, D. N. and A. E. Maxwell (1971). Factor analysis as a statistical method. London: Butterworth and Co.

Lever-Duffy, J. \& McDonald, J. (2003). Teaching and learning with technology. Boston, MA: Allyn and Bacon.

Levine, D., \& Lezotte, L. (1990). Unusually effective schools: A review and analysis of research and practice. Madison, WI: The National Center for Research and Development. 
Levine, J. (1998). Planning strategically for technology integration. Paper presented at the meeting of the Society for Information Technology and Teacher Education, Washington, DC.

Lezotte, L. W. (1989). The open book. Focus in Change, 1 (2), 3.

Lieberman, A. (Ed.). (1996, May). Rethinking professional development. Retrieved from http://www.ed.gov/pubs/IASA/newsletters/profdev/pt1.html

Lieberman, A., \& Miller, L. (1979). Staff development: New demands, new realities, and new perspectives. New York: Teachers College Press.

Little, J. W. (1982). Norms of collegiality and experimentation: Workplace conditions of school success. American Educational Research Journal, 19(3), 325-340.

Little, J.W. (1987). Teachers as colleagues. In V. Richardson-Koehler (Ed.), Educators' handbook (pp. 491-518). New York: Longman Press.

Lockwood, A. T. (1999). The promise and potential of professional development. Unpublished manuscript.

Loucks-Horsley, S. (1995, November). What the professional developer/designer does. Paper presented at the Education Development Center's Conference for Professional Development Teams for the 25 Statewide Systemic Initiatives, Baltimore, MD.

McNamara, E., \& McGillivray, K. (1999). Using Technology to Support Systemic Educational Reform., Cambridge, MA: TERC.

MacNeil, A. J. \& Delafield, D P. (1998). Principal leadership for successful school technology implementation. Paper presented at the meeting of the Society for Information Technology and Teacher Education, Washington, DC.

McKenzie, J. (1991). Designing staff development for the information age. Retrieved from http://staffdevelop.org/adult.html

McKenzie, J. (1998, April). Adult technology learning: Creating learning cultures with just-in-time support. Retrieved from http://staffdevelop.org/adult.html

Means, B. (1997). Using technology to enhance engaged learning for at-risk students. Retrieved from http://www.ncrel.org/sdrs/areas/issues/students/atrisk/at400.htm

Mehlinger, H. \& Powers, S. (2002). Technology \& Teacher Education: A guide for educators and policymakers. Boston, MA: Houghton Mifflin.

Miami-Dade County Public Schools. (2003). District and school profiles. Office of Educational Planning and Quality Enhancement: Miami, FL. 
Milken Exchange on Educational Technology. (1999). Seven dimensions for gauging progress of technology in the schools. Retrieved from http://www.milkenexchange.org/projects.taf_detail\&Content_uid1 $1=152$

Morgan, G. A., \& Griego, O. A. (1998). Easy use and interpretation of SPSS for windows: Answering research questions with statistics. Mahwah, NJ: Erlbaum.

National Board for Professional Teaching Standards. (n.d.). What teachers should know and be able to do (Policy Position statement). Retrieved from http:/www.nbpts.org/standards/know_do/policy.html

National Center for Education Statistics (2000). Digest of Education Statistics, 2000. Retrieved from www.ed.gov/pubs2001/digest.

National Staff Development Council. (2001). NSCD's standards for staff development, revised. Oxford. $\mathrm{OH}$ : Author.

National Staff Development Council. (n.d.). Standards for staff development. Retrieved from http://www.nsdc.org/standards/index.cfm

No Child Left Behind Act of 2001. Pub. L. No. 107-110, 15 Stat. 1425 (2002).

Oberg, D., Hay, L., \& Henri, J. (2000). The role of the principal in an information literate school community: Cross-country comparisons from an international research project. School Library Media Research.

Office of Educational Research and Improvement, U.S. Department of Education. (1994). Technology and education reform. Retrieved from http://www.ed.gov/pubs/EdReformStudies.

Office of Technology Assessment, U.S. Congress. (1995). Teachers and technology: Making the connection. Retrieved from http://www.wws.princeton.edu/ ota/

Panel on Educational Technology (1997). Report to the President on the use of technology to strengthen $\mathrm{K}-12$ education in the United States. Retrieved from http://www.ostp.gov/PCAST/k-12ed.html

Parsons, B. (2001). Evaluative inquiry: Using evaluation to promote school success. Thousand Oaks, CA: Sage Publications.

Patton, M. (1997). Utilization-focused evaluation: A new century text (3rd edition). Thousand Oaks, CA: Sage Publications.

Peterson, K. (2002). The professional development of principals: Innovations and opportunities. Educational Administration Quarterly, 38(2), 213-232.

Pflaum, W. (2004). The technology fix: The promise and reality in our schools. Alexandria, VA: ASCD.

Reitz, R. J. (1997). Lessons learned in creating a program. Kappa Delta Pi, 34(1), 4-9. 
Richey, R. C. \& Seels, B. (1994). Defining a field: A case study of the development of the 1994 definition of instructional technology. Englewood, CO.

Riedl, R., Smith, T., Ware, A., Wark, A., \& Yount, P. (1998, March). Leadership for a technology-rich educational environment. Paper presented at the meeting of The Society for Information Technology and Teacher Education, Washington, DC.

Ritchie, D., \& Rodriguez, S. (1997). The role of technology in school leadership. Journal of Information Technology for Teacher Education, 1(1), 111-124.

Roblyer, A. \& Edwards, J, C (1997). Integrating educational technology into teaching. Upper Saddle River, NJ: Prentice Hall.

Rossi, P., Freeman, H. \& Lispey, M. (1999). Evaluation: A systemic approach (6 $^{\text {th }}$ edition). Thousand Oaks, CA: Sage Publications.

Seels, B. B., \& Richey, R. C. (1994). Instructional technology: The definition and domains of the field. Washington DC: Association for Educational Communications and Technology.

Serim, F. (1996). Building virtual communities for professional development. Retrieved from http://www.ed.gov/Technology/Futures/serim.html

Shadish, W.R., Cook, T.D., \& Campbell, D.T. (2002). Experimental and quasiexperimental designs for generalized causal inference. Boston: HoughtonMifflin.

Smith, G. (1999). Teaching, learning, technology and effectiveness. NSWCEG Information IT Transfer, 19 (3), 20-31.

Smith, W., \& Andrews, R. (1990). Instructional leadership: How principals make a difference. Alexandria, VA: ASCD.

Sparks, D. \& Hirsh, S. (1997). A new vision for staff development. Oxford, OH: National Staff Development Council.

Sparks, D. (1994). A paradigm shift in staff development. Journal of Staff Development, 15(4), 26-29.

Sparks, D. (2002). Focusing staff development on improving the learning of all students. In Cawelti, G. (Ed.) Handbook of Research on Improving Student Achievement, Third Edition. Arlington, VA: Educational Research Service.

Sparks, D. And Loucks-Horsley, S. (1989). Five models of staff development. Retrieved from http://www.nsdc.org/library/publications/jsd/sparks104.cfm.

Speck, M. (1996, Spring). Best practice in professional development for sustained educational change. ERS Spectrum, 33-41. 
Speck, M., and Knipe C. (2001). Why Can't We Get It Right? Professional

Development in Our Schools. Thousand Oaks, CA: Corwin Press.

Tabachnick, B. G., \& Fidell, L. S. (2001). Using Multivariate Statistics, (4th ed.). Boston: Allyn and Bacon.

Tashakkori, A. \& Teddlie, C (2003). Handbook of mixed methods in social \& behavioral research. Thousand Oaks, CA: Sage Publications.

Technology Standards for School Administrators Collaborative. (2001). Technology standards for school administrators. North Central Regional Technology in Education Consortium. Dallas, TX.

Trotter, A. (1999, September 23). Preparing teachers for the digital age. Retrieved from http://www.edweek.org/sreports/tc99/articles/teach.htm

Trotter, A. (2001). Bennett's Online Education Venture Opens for Business. Education Week, pp.1-4. Retrieved 11, 2005 from www.edweek.org

Valdez, G. (1998). Learning through technology: A planning and implementation guide. Retrieved from http://www.ncrel.org/tandl/homepg.htm

Web-Based Education Commission (2001). The power of the internet for learning: Moving from promise to practice. Report to the President and Congress of the United States. Washington, DC.

Weiss, C., ed. (1972) Evaluating action programs. Boston: Allyn \& Bacon.

Wilde, J. (1996). Assessment strategies for professional development activities. Retrieved from http://www.ncbe.gwu.edu/miscpubs/eacwest/profdev/index.htm

Yocam, K. (1996). Conversation: An essential element of teacher development. In C. Fisher, D.C. Dwyer, \& K. Yocam (Eds.), Education and technology: Reflections on computing in classrooms (pp. 265-279). San Francisco: Jossey-Bass. 


\section{APPENDIX A}

Description of the Technology Standards for School Administrators (TSSA Collaborative, 2001) 
The Technology Standards for School Administrators (TSSA Collaborative, 2001) task force was composed of state education agency managers, school district technology coordinators, practitioners, and leaders. The TSSA task force identified the most commonly asked and most important questions about technology in schools.

Although, the TSSA document did not publish specific questionnaires, it presented the general framework, standards, and performance indicators that should be included when assessing technology integration in schools. Specifically, a well-designed questionnaire should address at least the following six fundamental topics (standards) and assess the degree of implementation of typical tasks that are expected of principals who effectively lead integration of technology in their schools.

1. The Leadership and Vision standard. The principal is expected to:

- Participate in an inclusive district process through which stakeholders formulate a shared vision that clearly defines expectations for technology use.

- Develop a collaborative, technology-rich school improvement plan, grounded in research and aligned with the district strategic plan.

- Promote highly effective practices in technology integration among faculty and other staff.

2. The Learning and Teaching standard. The principal is expected to:

- Assist teachers in using technology to access, analyze, and interpret student performance data, and in using results to appropriately design, assess, and modify student instruction. 
- Collaboratively design, implement, support, and participate in professional development for all instructional staff that institutionalizes effective integration of technology for improved student learning.

3. The Productivity and Professional Practice standard. The principal is expected to:

- Use current technology-based management systems to access and maintain personnel and student records.

- Use a variety of media and formats, including telecommunications and the school website, to communicate, interact, and collaborate with peers, experts, and other education stakeholders.

4. The Support, Management, \& Operations standard. The principal is expected to:

- Provide campus-wide staff development for sharing work and resources across commonly used formats and platforms.

- Allocate campus discretionary funds and other resources to advance implementation of the technology plan.

- Advocate for adequate, timely, and high-quality technology support services.

5. The Assessment and Evaluation standard. The principal is expected to:

- Promote and model the use of technology to access, analyze, and interpret campus data to focus efforts for improving student learning and productivity. 
- Implement evaluation procedures for teachers that assess individual growth toward established technology standards and guide professional development planning.

- Include effectiveness of technology use in the learning and teaching process as one criterion in assessing performance of instructional staff.

6. The Social, Legal, and Ethical Issues standard. The principal is expected to:

- Secure and allocate technology resources to enable teachers to better meet the needs of all learners on campus.

- Adhere to and enforce among staff and students the districts acceptable use policies and procedures related to security, copyright, and technology use.

- Participate in the development of facility plans that support and focus on health and environmentally safe practices related to the use of technology.

The questionnaires for this study was developed using the TSAA framework and included several sections. Each section included several questions, which were used to construct technology indicators to assess its degree of implementation at the schools. 


\section{APPENDIX B}

The Principal's Questionnaire 


\section{Florida International University \\ College of Education \\ Principal Survey for a Doctoral Research Study - 2004}

This survey is being conducted as part of a research study on "The impact of technology in elementary schools"; therefore any data collected will be used only for that purpose. The data will not be used individually and only group reporting will be made. Furthermore, the information you provide is and will remain anonymous. To that end, we urge you to be as candid as possible and answer all the questions to the best of your ability. Your opinions and experiences are an important part of this research study. Please mail the completed survey, using the self-addressed, stamped envelope.

For each of the following items, please provide the information requested or place a check in the box corresponding to your response.
A). Gender:
Male
Female
B). Ethnicity:
Asian
Black $\square$ Hispanic
White $\square$ Other, specify
C). Education: Please check all that apply:
B.A. or B.S.
M.A. or M.S.
Specialist
Ph.D.
Other, specify

D). Technology Education: Please check all that apply;
$\square$ a Degree in Technology $\square$ Only Technology Courses $\square$ No Technology Education

$\square$ Workshops \& Professional Development Other, specify

E). Principal-ship Experience: Please indicate the number of years as a school Principal:

Total years:

Years at the current school:

F). School Information: Please indicate the following:

Grade Configuration: (PK-5, K-8, etc)

$\%$ FRL:

G). Participation in specific technology projects: Please check all that apply.

\begin{tabular}{|l|l|l|l|}
\hline Did you participate in the following projects? & Yes & No & $\begin{array}{l}\text { Date } \\
\text { (Month and Year) }\end{array}$ \\
\hline Florida Leaders.Net (FLN) & & & \\
\hline Enhancing Education Through Technology (EETT) & & & \\
\hline
\end{tabular}




\begin{tabular}{|l|l|}
\hline 1. & $\begin{array}{l}\text { Which of the following BEST characterizes your school's technology plan? } \\
\text { (Please check only one) }\end{array}$ \\
\hline & $\begin{array}{l}\text { My school has its own published technology plan. } \\
\text { The technology plan is part of the School Improvement Plan. }\end{array}$ \\
\hline My school does not have a published technology plan. \\
\hline
\end{tabular}

\begin{tabular}{|l|l|}
\hline 2. & $\begin{array}{l}\text { If you have a technology plan for your school, please indicate who was MOST } \\
\text { involved in the preparation of this plan? (Please check only one) }\end{array}$ \\
\hline & \begin{tabular}{l} 
Administrators and faculty from our school. \\
Representatives from faculty, administration, parents, and technology specialists. \\
$\begin{array}{l}\text { Several stakeholders, including business partners, school and community } \\
\text { members. }\end{array}$ \\
$\begin{array}{l}\text { We adopted (with or without modifications) the district plan for our school } \\
\text { technology plan. }\end{array}$ \\
\hline
\end{tabular} \\
\hline
\end{tabular}

\begin{tabular}{|l|l|}
\hline 3. & $\begin{array}{l}\text { If you have a technology plan for your school, please indicate how this plan is } \\
\text { MOST likely to be implemented? (Please check only one) }\end{array}$ \\
\hline $\begin{array}{l}\text { Items in the plan will be implemented if there are extra funds in the school } \\
\text { budget. }\end{array}$ \\
\hline $\begin{array}{l}\text { Items in the plan are assigned specific amounts in the school budget. } \\
\text { Items in the plan will be implemented from grants, and other outside resources. }\end{array}$ \\
\hline
\end{tabular}

\begin{tabular}{|l|l|}
\hline 4. & $\begin{array}{l}\text { If you have a technology plan for your school, please indicate who has the } \\
\text { PRIMARY responsibility for monitoring the implementation of the plan? (Please } \\
\text { check only one) }\end{array}$ \\
\hline & $\begin{array}{l}\text { The principal. } \\
\text { A technology committee. } \\
\text { A specific person, Please specify who?: }\end{array}$ \\
\hline
\end{tabular}




\begin{tabular}{|l|l|l|l|l|}
\hline 5. & $\begin{array}{l}\text { Whether you have a technology plan or not, please rate EACH of the following } \\
\text { statements to describe your goals for using technology at your school in the } \\
\text { order of their importance (1 = Least important, 4=Most important). }\end{array}$ \\
\hline & & 1 & 3 & 4 \\
\hline To provide instruction to many of our students. & & & \\
\hline $\begin{array}{l}\text { To support student success through proven teaching \& learning } \\
\text { principles. }\end{array}$ & & & \\
\hline To simplify administrative tasks, and to enhance school management. & & & \\
\hline To address higher order teaching and learning with all our students. & & & \\
\hline
\end{tabular}

\begin{tabular}{|c|c|c|c|c|c|}
\hline \multirow[t]{2}{*}{6.} & \multicolumn{5}{|c|}{$\begin{array}{l}\text { There are several factors influencing technology related decision-making, such } \\
\text { as the purchase of hardware and software. In your school, please rate EACH of } \\
\text { these factors in the order of their importance }(1=\text { Least important, } 4=\text { Most } \\
\text { important) in the decision-making process regarding technology issues? }\end{array}$} \\
\hline & & 1 & 2 & 3 & 4 \\
\hline \multicolumn{2}{|r|}{ Recommendations from hardware or software vendors. } & & & & \\
\hline \multicolumn{2}{|c|}{ Recommendations from the faculty. } & & & & \\
\hline \multicolumn{2}{|r|}{ Recommendations or mandates from the district. } & & & & \\
\hline \multicolumn{2}{|c|}{ Experience of other schools. } & & & & \\
\hline \multicolumn{2}{|r|}{ Results of published research on the use of technology. } & & & & \\
\hline \multicolumn{2}{|c|}{ Other, Please specify: } & & & & \\
\hline
\end{tabular}

\begin{tabular}{|l|l|l|}
\hline $\begin{array}{l}\text { In the area of Professional Development (PD) opportunities in technology } \\
\text { during the current school year, please indicate the following: } \\
\text { 1. The number of PD opportunities in technology attended by each group. } \\
\text { 2. The number of participants in each group. }\end{array}$ \\
\hline Group & \# Technology PD attended & $\begin{array}{l}\text { No. of } \\
\text { Participants }\end{array}$ \\
\hline Principal/ Assistant Principals. & & \\
\hline Teachers. & & \\
\hline Office staff. & & \\
\hline Other, Please specify: & & \\
\hline
\end{tabular}




\begin{tabular}{|c|l|l|l|l|}
\hline \begin{tabular}{|l|l|} 
In the area of technical support for the current school year, please indicate \\
the following: \\
a. Check if you have that type of technical support \\
b. Indicate if that type of support is part time or full time
\end{tabular} \\
\hline Technical support is provided by ... & Yes & No & Part-Time Full Time \\
\hline Technology Coordinator. & & & & \\
\hline Instructional Technology Specialist. & & & & \\
\hline Region Staff. & & & & \\
\hline District Staff. & & & & \\
\hline Other, Please specify: & & & \\
\hline
\end{tabular}

\begin{tabular}{|r|l|}
\hline \multicolumn{1}{|c|}{9.} & $\begin{array}{l}\text { If you have any type of technical support, what percentage of that support is } \\
\text { for ... }\end{array}$ \\
\hline$\ldots \ldots \%$ & Basic technical support (Operating, repairing, etc.) \\
\hline$\ldots \ldots \%$ & Support for basic software (Word-processing, Spreadsheet, PowerPoint...). \\
\hline$\ldots \ldots \%$ & Curriculum Integration (GSP, CCC, Jostens). \\
\hline$\ldots \ldots \%$ & Other, Please specify: \\
\hline
\end{tabular}

\begin{tabular}{|l|l|}
\hline 10. & $\begin{array}{l}\text { In your opinion, the school's budget (regardless of the source) for technology } \\
\text { infrastructure (hardware and software) is ... } \\
\text { (Check only one) }\end{array}$ \\
\hline $\begin{array}{l}\text { Not sufficient to maintain your current level of technology. } \\
\text { Sufficient to maintain your current level of technology. }\end{array}$ \\
\hline $\begin{array}{l}\text { Sufficient for current level \& for purchase of new equipment and/or software. } \\
\text { I do not have a school-based budget for technology at my school. }\end{array}$ \\
\hline
\end{tabular}




\begin{tabular}{|l|l|l|}
\hline 11. & $\begin{array}{l}\text { Please indicate (approximately) how much funding did your school receive } \\
\text { for technology from each of these funding sources for the current school } \\
\text { year? }\end{array}$ & $\begin{array}{l}\text { Amount } \\
\$\end{array}$ \\
\hline Funding Source & $\$$ \\
\hline District (funds from the district for technology). & $\$$ \\
\hline School (amount your school decided to earmark for technology). & $\$$ \\
\hline Federal and/or State Grants (directly obtained by your school). & $\$$ \\
\hline Foundations (NSF, NASA,...). & $\$$ \\
\hline Donations/Fundraising (parents, community, PTA, ...). & $\$$ \\
\hline
\end{tabular}

\begin{tabular}{|l|l|l|}
\hline 12. & \begin{tabular}{l} 
Please indicate the number of equipment in each of the following categories \\
that are exclusively used for INSTRUCTIONAL purposes. \\
\hline Equipment type/category
\end{tabular} & Number \\
\hline Modern Computers (Multimedia and Internet capable). & \\
\hline Non-Modern Computers (Not Multimedia and/or Internet capable). & \\
\hline Laptops. & \\
\hline Network-connected computers. & \\
\hline Internet-connected computers. & \\
\hline Projection systems. & \\
\hline Digital cameras.
\end{tabular}




\begin{tabular}{|l|l|l|l|l|}
\hline 13. & \multicolumn{4}{|l|}{$\begin{array}{l}\text { Consider all computers in your school, which are used exclusively for } \\
\text { instructional purposes. Please indicate the percentage of these computers } \\
\text { which are EQUIPPED with the following types of software: }\end{array}$} \\
\hline Type of software & $0-25 \%$ & $\mathbf{2 6 - 5 0 \%}$ & $\mathbf{5 1 - 7 5 \%}$ & $\begin{array}{l}76- \\
100 \%\end{array}$ \\
\hline Word processing. & & & & \\
\hline Spreadsheet, Databases (e.g. Excel, Access). & & & & \\
\hline Hypermedia/Multimedia (e.g. HyperStudio). & & & & \\
\hline Presentation software (e.g. PowerPoint). & & & & \\
\hline Drill and Practice Programs and Tutorials. & & & & \\
\hline Simulation Programs. & & & \\
\hline Other (Please specify): & & & & \\
\hline
\end{tabular}

\begin{tabular}{|c|c|c|c|c|c|}
\hline 14. & \multicolumn{5}{|c|}{$\begin{array}{l}\text { In your opinion, what is the percentage of teachers in your school who } \\
\text { REGULARLY use technology in the following ways? }\end{array}$} \\
\hline \multicolumn{2}{|c|}{ Activity } & $0-25 \%$ & $26-50 \%$ & $51-75 \%$ & $\begin{array}{l}76- \\
100 \%\end{array}$ \\
\hline \multicolumn{6}{|c|}{ Administrative \& management tasks. } \\
\hline \multicolumn{6}{|c|}{ Curriculum and lesson planning. } \\
\hline \multicolumn{6}{|c|}{ Instruction delivery. } \\
\hline \multicolumn{6}{|c|}{ Communication with students and/or parents. } \\
\hline \multicolumn{6}{|c|}{ Assessment and Data Analysis (FCAT, SAT). } \\
\hline Oth & (Please specify): & & & & \\
\hline
\end{tabular}




\begin{tabular}{|c|l|l|l|l|l|}
\hline 15. & \multicolumn{3}{|l|}{$\begin{array}{l}\text { As a principal, which of the following usages of technology have you actively } \\
\text { PROMOTED during this year in your school? Rate EACH usage (1 = Least } \\
\text { Promoted, 4 = Most promoted) }\end{array}$} \\
\hline \multicolumn{2}{|l|}{ Learning collaboratively within the classroom. } & & & & \\
\hline Researching via the Internet. & & & & \\
\hline Creating authentic learning environments. & & & & \\
\hline Teaching about technology. & & & & \\
\hline Sharing of published research on the use of technology. & & & & \\
\hline Other, Please specify: & & & & \\
\hline
\end{tabular}

\begin{tabular}{|l|l|l|l|l|}
\hline 16. & $\begin{array}{l}\text { As a principal, to what degree do you AGREE with the following approaches to } \\
\text { technology leadership? Please rate EACH approach (1= Least agreement, } 4= \\
\text { Strong agreement) }\end{array}$ \\
\hline & 1 & 2 & 3 & 4 \\
\hline Model to faculty and staff the effective use of technology. & & & & \\
\hline $\begin{array}{l}\text { Use technology for communication with staff, faculty, parents, and } \\
\text { the community. }\end{array}$ & & & & \\
\hline $\begin{array}{l}\text { Engage in sustained, job related professional development using } \\
\text { technology. }\end{array}$ & & & \\
\hline Use technology for school improvement. & & & \\
\hline
\end{tabular}




\begin{tabular}{|c|c|c|c|c|c|}
\hline \multirow[t]{2}{*}{17.} & \multicolumn{5}{|c|}{$\begin{array}{l}\text { How do you usually provide technology-related professional development for your } \\
\text { Non-Instructional STAFF? Please rate EACH of these methods ( } 1=\text { Least used, } \\
4=\text { Most used). }\end{array}$} \\
\hline & & 1 & 2 & 3 & 4 \\
\hline \multicolumn{2}{|c|}{ Lectures and/or presentations. } & & & & \\
\hline \multicolumn{2}{|c|}{ Hands-on training. } & & & & \\
\hline \multicolumn{2}{|c|}{ Workshops addressing the specific needs of the school. } & & & & \\
\hline \multicolumn{2}{|c|}{ Other (Please specify): } & & & & \\
\hline
\end{tabular}

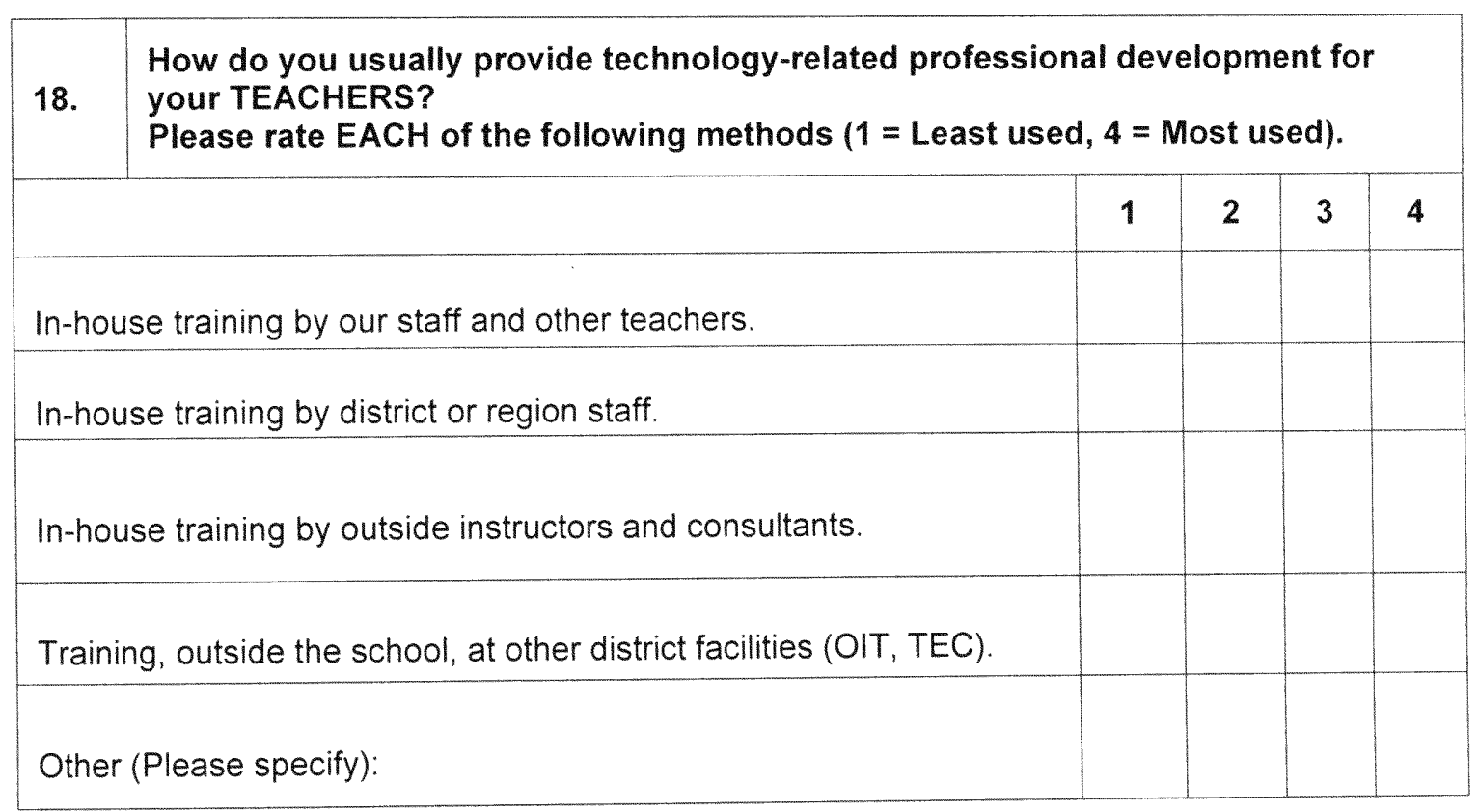




\begin{tabular}{|c|c|c|c|c|c|}
\hline 19. & \multicolumn{5}{|c|}{$\begin{array}{l}\text { In your opinion, what is the percentage of teachers in your school that need } \\
\text { training and/or professional development in the following areas? }\end{array}$} \\
\hline \multicolumn{2}{|c|}{ Training Needs } & $0-25 \%$ & $26-50 \%$ & $51-75 \%$ & $76-100 \%$ \\
\hline \multicolumn{6}{|c|}{$\begin{array}{l}\text { Basic computer skills (e.g. Operating system, } \\
\text { accessing the network, and using email, etc). }\end{array}$} \\
\hline \multicolumn{6}{|c|}{$\begin{array}{l}\text { Administrative and management applications } \\
\text { (e.g. grade books, lesson planning, and record } \\
\text { keeping). }\end{array}$} \\
\hline \multicolumn{6}{|c|}{$\begin{array}{l}\text { Other specific curriculum applications (e.g. GSP, } \\
\text { etc). }\end{array}$} \\
\hline \multicolumn{6}{|c|}{ Integration of technology and curriculum. } \\
\hline \multicolumn{6}{|c|}{ Emerging technologies in education. } \\
\hline Other & lease specify): & & & & \\
\hline
\end{tabular}

\begin{tabular}{|c|c|c|c|c|c|}
\hline \multirow[t]{2}{*}{20.} & \multicolumn{5}{|c|}{$\begin{array}{l}\text { In which of the following ways, do teachers at your school use technology? } \\
\text { Please rate EACH of these ways ( } 4 \text { = Least used, } 1=\text { Most used). }\end{array}$} \\
\hline & & 1 & 2 & 3 & 4 \\
\hline \multicolumn{6}{|c|}{ To promote more individualized instruction. } \\
\hline \multicolumn{6}{|c|}{$\begin{array}{l}\text { To promote interdisciplinary activities and links to real-world } \\
\text { applications. }\end{array}$} \\
\hline \multicolumn{6}{|c|}{ To promote heterogeneous grouping of students. } \\
\hline \multicolumn{6}{|c|}{ To perform administrative and record keeping tasks. } \\
\hline & rd and/or challenge specia & & & & \\
\hline
\end{tabular}




\begin{tabular}{|c|c|c|c|c|c|}
\hline \multirow[t]{2}{*}{21.} & \multicolumn{5}{|c|}{$\begin{array}{l}\text { Which of the following tools do you use when sharing information about your } \\
\text { school with your community? Please rate EACH of these tools ( } 1=\text { Least used, } \\
4=\text { Most used). }\end{array}$} \\
\hline & & 1 & 2 & 3 & 4 \\
\hline \multicolumn{6}{|c|}{ Email. } \\
\hline \multicolumn{6}{|c|}{ School/district website. } \\
\hline \multicolumn{6}{|c|}{ Telephone homework hotline. } \\
\hline \multicolumn{6}{|c|}{ Voice bulletins/voice mail. } \\
\hline Othe & Please Specify): & & & & \\
\hline
\end{tabular}

\begin{tabular}{|c|c|c|c|c|c|}
\hline \multirow[t]{2}{*}{22.} & \multicolumn{5}{|c|}{$\begin{array}{l}\text { As a principal, which of the following technology related elements do you } \\
\text { consider when evaluating your teachers? Rate each }(1=\text { Least included, } 4=\text { Most } \\
\text { included). }\end{array}$} \\
\hline & & 1 & 2 & 3 & 4 \\
\hline \multicolumn{2}{|c|}{$\begin{array}{l}\text { The effectiveness of technology use/application in the } \\
\text { classroom. }\end{array}$} & & & & \\
\hline \multicolumn{2}{|c|}{ The teacher growth in technology knowledge. } & & & & \\
\hline \multicolumn{2}{|r|}{$\begin{array}{l}\text { The effort of the teacher towards the promotion of technology } \\
\text { in school. }\end{array}$} & & & & \\
\hline \multicolumn{2}{|r|}{ I only use the approved M-DCPS-UTD evaluation instrument. } & & & & \\
\hline
\end{tabular}


23. Please indicate the frequency of using the following methods to monitor teacher competency in technology? Rate each statement ( $1=$ Least used, $4=$ Most used).

\begin{tabular}{|l|l|l|l|l|}
\hline & 1 & 2 & 3 & 4 \\
\hline Teacher surveys. & & & & \\
\hline Teacher tests. & & & & \\
\hline Classroom observation. & & & & \\
\hline Time spent in technology training. & & & & \\
\hline Tracking through a training program management system. & & & & \\
\hline Other (please specify): & & & & \\
\hline
\end{tabular}

\begin{tabular}{|c|c|c|c|c|c|}
\hline \multirow{2}{*}{$\begin{array}{l}24 . \\
\text { Poli }\end{array}$} & \multicolumn{5}{|c|}{$\begin{array}{l}\text { Describe the current status of your school POLICY in technology use: } \\
\begin{array}{ll}\text { 1. We do not have a policy } & \text { 3. We have a formal, partially implemented } \\
\text { policy } & \end{array} \\
\begin{array}{ll}\text { 2. We have an informal policy } & \text { 4. We have a formal, fully implemented policy }\end{array}\end{array}$} \\
\hline & & 1 & 2 & 3 & 4 \\
\hline \multicolumn{6}{|c|}{ Acceptable uses of technology by students. } \\
\hline \multicolumn{6}{|c|}{ Acceptable uses of technology by non-instructional staff. } \\
\hline \multicolumn{6}{|c|}{ Acceptable uses of technology by faculty and teachers. } \\
\hline \multicolumn{6}{|c|}{ Acceptable uses of technology by volunteers. } \\
\hline Dis & lines for technology-related offenses. & & & & \\
\hline
\end{tabular}


APPENDIX C

The Teachers and Media Specialists' Questionnaires 


\section{Florida International University \\ College of Education \\ Teacher Survey for a Doctoral Research Study - 2004}

This survey is being conducted as part of a research study on "The impact of technology in elementary schools"; therefore any data collected will be used only for that purpose. The data will not be used individually and only group reporting will be made. Furthermore, the information you provide is and will remain anonymous. To that end, we urge you to be as candid as possible and answer all the questions to the best of your ability. Your opinions and experiences are an important part of this research study. For each of the following items, please provide the information requested or place a check $(\checkmark)$ in the box corresponding to your response.

1. School Name:

School Location \#:

2. Grade(s) level you are currently teaching:

3. Number of years at this school:

4. Teaching experience:

Number of years in Miami-Dade Schools:

Total Number of years teaching:

5. Highest degree completed:
Bachelors
Masters
Specialist
Doctorate
Other, specify

6. What type of computer equipment do you have access to at your school for your students? (Check all that apply)

Modern Computers (Multimedia and Internet capable)

$\square$ Non-Modern Computers (Not Multimedia and /or Internet capable)

Network-connected computers

Internet-connected computers

Projection systems

Digital cameras

Other, please specify 
7. What types of software are installed on the computers that are used exclusively for instructional purposes at your school? (Check all that apply)

Word processing

Spreadsheet, Databases (e.g. Excel, Access)

Hypermedia/Multimedia (e.g. Hyper-Studio)

$\square$ Presentation Software (e.g. Powerpoint)

$\square$ Drill and Practice Programs and Tutorials

Simulation Programs

Other, please specify

8. Do you have computers inside your classroom? $\square$ Yes $\square$ No

Based on your experience teaching this year, at the current school, please indicate your response to the following items by circling one of the following: "SD" for strongly disagree, " $D$ " for disagree, " $A$ " for agree, and "SA" for strongly agree. Circle "N/A" if the item is not applicable to you.

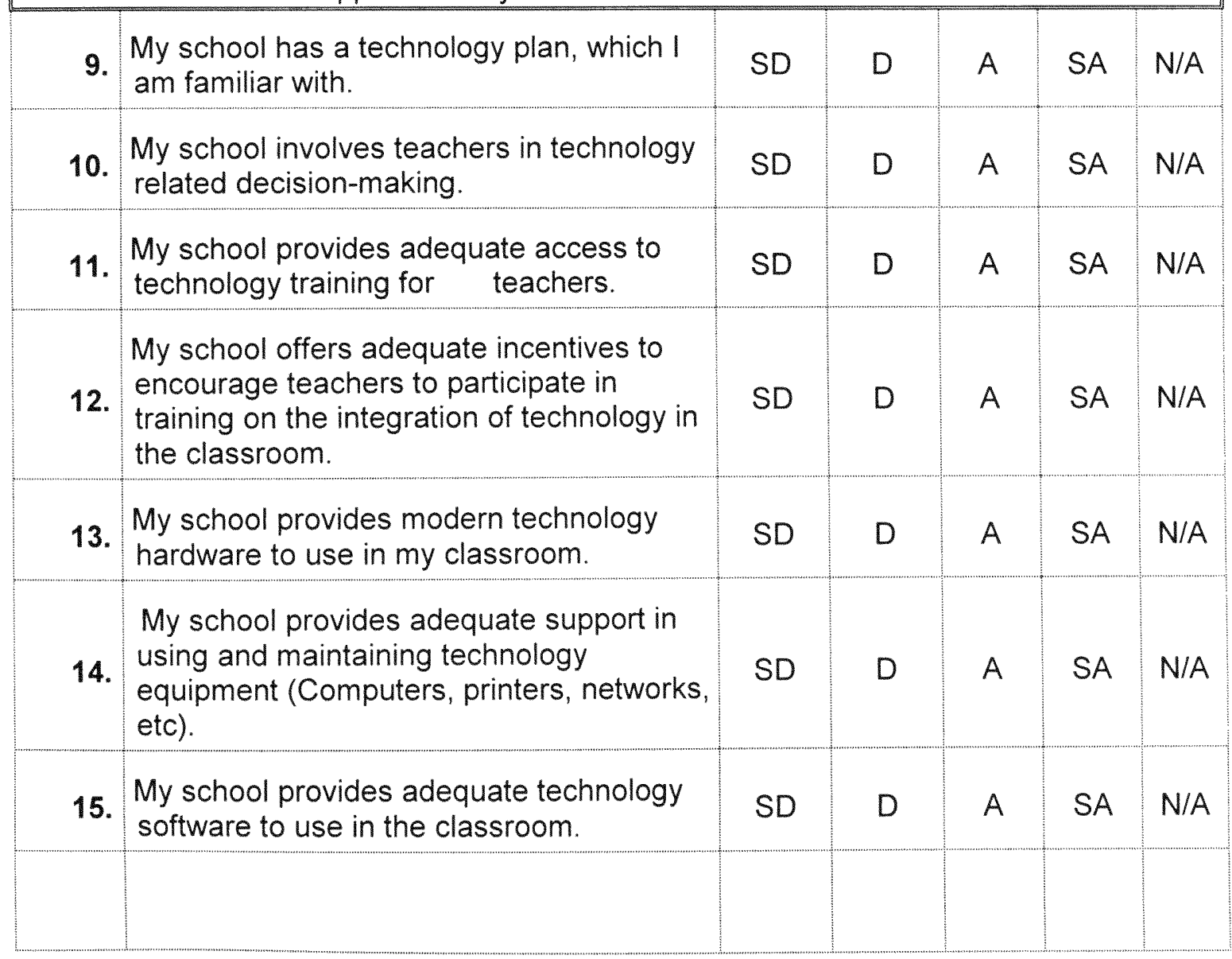


Based on your experience teaching this year, at the current school, please indicate your response to the following items by circling one of the following: "SD" for strongly disagree, " $D$ " for disagree, " $A$ " for agree, and "SA" for strongly agree. Circle "N/A" if the item is not applicable to you.

My school provides adequate support in

16. installing and using software applications (basic software and curriculum software).

17.

My principal models to teachers the effective use of technology.

My principal uses technology in presentations to teachers.

My principal uses technology to communicate with teachers.

My principal is a strong advocate for the

20. use of technology at my school (provides financial and leadership support).

My principal involves business partners and community members in the

21. development and enhancement of technology at my school.

My school uses current technology-based

22. management systems to access and maintain personnel and student records.

23. My school provides in-house school-wide technology staff development for teachers.

My school adheres to and enforces policies

24. and procedures related to acceptable use of technology (Copyright, security, ethical practices).

25. My principal monitors teachers' competency in technology.

My principal suggests technology as an

26. area of growth for teachers who need it.

\begin{tabular}{|c|c|c|c|c|}
\hline$S D$ & $D$ & $A$ & $S A$ & N/A \\
\hline$S D$ & $D$ & $A$ & SA & N/A \\
\hline$S D$ & $D$ & $A$ & SA & N/A \\
\hline SD & $D$ & $A$ & $S A$ & N/A \\
\hline$S D$ & $D$ & $A$ & $S A$ & $N / A$ \\
\hline SD & $D$ & $A$ & SA & N/A \\
\hline$S D$ & $D$ & A & $S A$ & N/A \\
\hline$S D$ & $D$ & $A$ & $S A$ & N/A \\
\hline$S D$ & $D$ & $A$ & SA & N/A \\
\hline$S D$ & $D$ & A & $S A$ & N/A \\
\hline$S D$ & $D$ & $A$ & $S A$ & N/A \\
\hline
\end{tabular}


In your opinion, please indicate (to the best of your knowledge) the percentage of teachers (at your school this year) in each of the following categories. Circle "N/A" if the category is not applicable to you or you do not know the answer.

\begin{tabular}{|c|c|c|c|c|c|c|}
\hline & & $0.25 \%$ & $26-50 \%$ & $51.75 \%$ & $76-100 \%$ & $N / A$ \\
\hline 27. & $\begin{array}{l}\text { Percentage of teachers needing training } \\
\text { in basic computer skills. }\end{array}$ & 0.25 & $26-50$ & $51-75$ & $76-100$ & $N / A$ \\
\hline 28. & $\begin{array}{l}\text { Percentage of teachers needing training } \\
\text { in administrative and management } \\
\text { applications (e.g. Grade book, lesson } \\
\text { planning, and record keeping). }\end{array}$ & 0.25 & $26-50$ & $51-75$ & $76-100$ & $N / A$ \\
\hline 29. & $\begin{array}{l}\text { Percentage of teachers needing training } \\
\text { in the integration of technology and } \\
\text { curriculum. }\end{array}$ & 0.25 & $26-50$ & $51-75$ & $76-100$ & $N / A$ \\
\hline 30. & $\begin{array}{l}\text { Percentage of teachers who regularly } \\
\text { use technology for administrative and } \\
\text { management tasks (Record keeping). }\end{array}$ & 0.25 & $26-50$ & $51-75$ & $76-100$ & $N / A$ \\
\hline 31. & $\begin{array}{l}\text { Percentage of teachers who regularly } \\
\text { use technology for student assessment } \\
\text { and data analysis (FCAT, SAT, etc...). }\end{array}$ & 0.25 & $26-50$ & $51-75$ & $76-100$ & $N / A$ \\
\hline 32. & $\begin{array}{l}\text { Percentage of teachers who regularly } \\
\text { use technology to communicate with } \\
\text { students and/or parents. }\end{array}$ & $0-25$ & $26-50$ & $51-75$ & $76-100$ & $N / A$ \\
\hline 33. & $\begin{array}{l}\text { Percentage of teachers who regularly } \\
\text { use technology in the delivery of } \\
\text { instruction at their classrooms. }\end{array}$ & $0-25$ & $26-50$ & $51-75$ & $76-100$ & $N / A$ \\
\hline 34. & $\begin{array}{l}\text { Percentage of teachers who regularly } \\
\text { use technology to promote collaborative } \\
\text { learning within the classroom. }\end{array}$ & $0-25$ & $26-50$ & $51-75$ & $76-100$ & $N / A$ \\
\hline 35. & $\begin{array}{l}\text { Percentage of teachers who regularly } \\
\text { use technology to promote researching } \\
\text { via the Internet. }\end{array}$ & 0.25 & $26-50$ & $51-75$ & $76-100$ & $N / A$ \\
\hline 36. & $\begin{array}{l}\text { Percentage of teachers who regularly } \\
\text { use technology to create authentic } \\
\text { learning environment. }\end{array}$ & $0-25$ & $26-50$ & $51-75$ & $76-100$ & $N / A$ \\
\hline 37. & $\begin{array}{l}\text { Percentage of teachers who regularly } \\
\text { use technology to teach about } \\
\text { technology. }\end{array}$ & 0.25 & $26-50$ & $51-75$ & $76-100$ & $N / A$ \\
\hline
\end{tabular}


39. If you wish to provide additional comments, please do so. 


\section{APPENDIX D}

Analyses of Principals, Teachers, and Media Specialists' Responses to Questions Pertaining to the Use of Technology in Management and Operations, in Teaching and Learning, and in Assessment and Evaluation. 
This appendix presents the details of the results that were summarized in Chapter IV. Specifically, it presents analyses of the responses to individual items pertaining to the use of technology a) in Management and Operation (TMO), b) in the Learning and Teaching (TLT) environment, and c) in the Assessment and Evaluation (TAE).

The participants in this study were principals, classroom teachers, and media specialists. Each group of participants completed a specific questionnaire measuring various aspects of technology utilization across the school.

\section{Use of Technology in Management and Operations}

Subsidiary Research Question 1: What was the difference in the use of Technology in Management and Operation between schools whose principals participated in the FloridaLeaders.net and those who did not participate?

The purpose of this question is to assess the degree to which the school integrates technology to support productive systems for management and operation. Technology indicators (dimensions) included: The availability of commonly used up-to-date hardware resources across the school, the availability of commonly used up-to-date software programs across the school, the level of usage of technology systems to manage the operations of the school, and the level of technology usage at the classroom level to prepare lessons and/or manage students' records.

\section{Principals' Responses}

In the Principal questionnaire, principals were asked six questions pertaining to the use of Technology in Management and Operations. The principals were asked to rate their own use of Technology in the area of Management and Operations, and also were asked to rate their teachers' use of technology in that same area. 


\begin{tabular}{|c|c|c|c|c|c|c|}
\hline \multirow{2}{*}{ Item } & \multicolumn{3}{|c|}{ FLN Principals } & \multicolumn{3}{|c|}{$\begin{array}{l}\text { Non-FLN } \\
\text { Principals }\end{array}$} \\
\hline & $\mathrm{n}$ & M & $\mathrm{SD}$ & $\mathrm{n}$ & M & $\mathrm{SD}$ \\
\hline $\begin{array}{l}\text { Teachers' use of technology to perform } \\
\text { administrative and management tasks }\end{array}$ & 27 & 2.67 & 1.14 & 14 & 2.71 & 1.20 \\
\hline $\begin{array}{l}\text { Teachers' use of technology to } \\
\text { communicate with students and/or } \\
\text { parents }\end{array}$ & 27 & 1.89 & .89 & 14 & 2.00 & .78 \\
\hline $\begin{array}{l}\text { Teachers' use of technology perform } \\
\text { administrative and record keeping tasks }\end{array}$ & 27 & 2.93 & .78 & 14 & 2.64 & .84 \\
\hline $\begin{array}{l}\text { Principal attitude in using technology } \\
\text { to enhance administrative and } \\
\text { management tasks. }\end{array}$ & 28 & 2.57 & 1.10 & 13 & 3.08 & .95 \\
\hline $\begin{array}{l}\text { Principal use of email and school } \\
\text { website for communication. }\end{array}$ & 26 & 2.92 & 1.09 & 13 & 2.77 & 1.36 \\
\hline $\begin{array}{l}\text { Teachers training needs in how to use } \\
\text { technology to perform administrative } \\
\text { and management tasks. }\end{array}$ & 26 & 3.50 & .81 & 14 & 3.14 & .86 \\
\hline
\end{tabular}

Descriptive analyses of these items are listed in Table D.1.1. The results revealed that the highest means for both groups were 3.50 and 3.14, and pertained to the "teachers training need in how to use technology to perform administrative and management tasks". The lowest means were 1.89 and 2.00 , and pertained to the teachers' actual use of technology to communicate with students and/or parents. This finding suggests that, from 
the principals' point of view and assessment, the teachers do not use enough technology to communicate with students and/or parents.

\section{Teachers' Responses}

In the Teacher questionnaire, teachers were asked seven items pertaining to the use of technology in Management and Operations. Table D.1.2 presents the means and standards deviations for the seven items for FLN and Non-FLN groups.

Table D.1.2

Use of Technology for Management and Operations: Teachers' Responses.

FLN Schools Non FLN Schools

Item

\begin{tabular}{llllll}
\hline $\mathrm{n}$ & $\mathrm{M}$ & $\mathrm{SD}$ & $\mathrm{n}$ & $\mathrm{M}$ & $\mathrm{SD}$ \\
\hline
\end{tabular}

Teachers' use of technology to perform administrative and management tasks

$\begin{array}{llllll}65 & 1.83 & 1.00 & 61 & 2.26 & 1.16\end{array}$

Teachers' use of technology to communicate with students/ parents

$\begin{array}{llllll}64 & 1.72 & .93 & 60 & 1.92 & 1.04\end{array}$

Teachers' professional development needs in how to use technology to perform administrative and $\begin{array}{llllll}65 & 2.35 & 1.17 & 58 & 2.12 & 1.10\end{array}$ management tasks

Principals' use of technology in presentation to teachers

$\begin{array}{llllll}77 & 2.97 & .87 & 72 & 2.97 & .91\end{array}$

Principals' use of technology to communicate with teachers

$\begin{array}{llllll}78 & 3.23 & .86 & 73 & 3.10 & .91\end{array}$

Principals' use of technology-based management systems to access and maintain personnel and student records

$\begin{array}{llllll}72 & 3.10 & .89 & 70 & 3.00 & .88\end{array}$

Principals' use of technology to monitor teacher competency in technology

$\begin{array}{llllll}71 & 2.92 & .95 & 67 & 2.40 & .79\end{array}$


The highest means for both groups were 3.23 and 3.10 and pertained to the "principals' use of technology to communicate with teachers". The lowest means were 1.72 and 1.92 , and pertained to the teachers' actual use of technology to communicate with students and/or parents. This finding is also consistent with that of the principals' assessment that teachers do not use enough technology to communicate with students and/or parents.

\section{Media Specialists' Responses}

In the Media Specialists questionnaire, media specialists were asked seven questions pertaining to the use of technology in Management and Operations.

The highest means for both groups were 3.19 and 3.03 and pertained to the "principals' use of technology-based management systems to access and maintain personnel and student records". This may mean that principals are using standard technology applications to maintain student academic records, personnel and staff data, such as payroll, and other demographic information. The lowest means were 2.70 and 2.77 and pertained to the principals' use of technology in presentation to teachers. This finding suggests that the principals are not modeling the use of technology and are using it in front of teachers such multi-media or power point presentations. 
Table D.1.3

Use of Technology in Management and Operations: Media specialists' Responses.

Item

FLN Schools Non FLN Schools

\begin{tabular}{llllll}
\hline $\mathrm{n}$ & $\mathrm{M}$ & $\mathrm{SD}$ & $\mathrm{n}$ & $\mathrm{M}$ & $\mathrm{SD}$
\end{tabular}

Teachers' use of technology to perform administrative and management tasks

$\begin{array}{llllll}66 & 2.21 & 1.03 & 34 & 2.06 & 1.09\end{array}$

Teachers' use of technology to

communicate with students and/or parents

$\begin{array}{llllll}60 & 2.00 & 1.05 & 33 & 1.76 & 1.03\end{array}$

Teachers' professional development needs in how to use technology to perform administrative and management tasks.

$\begin{array}{llllll}65 & 2.71 & 1.05 & 36 & 2.53 & 1.23\end{array}$

Principals' use of technology in presentation to teachers

$\begin{array}{llllll}66 & 2.70 & .94 & 43 & 2.77 & .92\end{array}$

Principals' use of technology to communicate with teachers

$\begin{array}{llllll}67 & 2.79 & .94 & 42 & 2.98 & .95\end{array}$

Principals' use of technology-based management systems to access and maintain personnel and student records

$\begin{array}{llllll}63 & 3.19 & .80 & 33 & 3.03 & .77\end{array}$

Principals' use of technology to monitor teacher competency in technology

$\begin{array}{llllll}64 & 2.75 & .83 & 38 & 2.61 & .82\end{array}$ 


\section{Use of Technology in the Teaching and Learning Environment}

Subsidiary Research Question 2: What was the difference in the use of Technology in the Learning and Teaching environment (classrooms) between schools whose principals participated in the FloridaLeaders.net and those who did not participate?

The purpose of this question is to assess the degree to which the school ensures that curricular design, and instructional strategies integrate appropriate technologies to maximize learning and teaching.

To assess the use of technology in the learning and teaching environment (classrooms), items were constructed and were included in all three questionnaires. All participants were asked questions to assess their own use and attitudes toward technology (self and peer-reporting) and also were asked to assess others.

\section{Principals' Responses}

In the Principal questionnaire, principals were asked ten questions pertaining to the use of technology in the learning and teaching environment (classrooms). Descriptive analyses of these items are listed in Table A.6. The highest means for both groups were 3.50 and 3.57 indicating that principals' main goal for using technology in teaching and learning is to provide instruction to students. The rating of the other purposes of usages of technology in teaching and learning were also high (3.21 to 3.36). These usages mentioned were to: a) support students success through proven teaching and learning principles, b) address higher order of teaching and learning, and c) promote collaborative learning in the classroom. The teachers' use of technology in instruction was rated the lowest $(M=2.26)$ and $(M=2.00)$ for FLN principals and Non-FLN principals respectively. 
Table D.2.1

Use of Technology in the Learning and Teaching Environment: Principals' Responses

FLN Schools Non FLN Schools

Item

n $\quad M \quad$ SD $\quad \mathrm{n} \quad \mathrm{M} \quad \mathrm{SD}$

Use of technology to provide instruction to students.

$\begin{array}{llllll}28 & 3.50 & .74 & 14 & 3.57 & .93\end{array}$

Use of technology to support students' success through proven teaching and learning principles.

$\begin{array}{llllll}28 & 3.36 & .87 & 14 & 3.21 & 1.12\end{array}$

Use of technology to address higher order $\begin{array}{lllllll}\text { of teaching and learning with all students. } & 28 & 3.46 & .74 & 14 & 3.36 & 1.08\end{array}$ Use of technology to promote collaborative learning in the classroom.

$\begin{array}{llllll}27 & 3.30 & .86 & 14 & 3.29 & .99\end{array}$

The school promotes technology to create authentic learning environment.

$\begin{array}{llllll}27 & 2.59 & 1.01 & 13 & 2.15 & .68\end{array}$

Teachers' use of technology to develop curriculum and lesson planning.

$\begin{array}{llllll}27 & 2.37 & .83 & 14 & 2.43 & .75\end{array}$

Teacher's use of technology in instruction.

Teachers' use technology to promote more individualized instruction.

$\begin{array}{llllll}27 & 2.26 & .90 & 14 & 2.00 & .39\end{array}$

Teachers' use technology to promote interdisciplinary activities.

$\begin{array}{llllll}27 & 2.85 & .98 & 14 & 2.64 & .92\end{array}$

Teachers' use of technology to promote heterogeneous grouping of students.

$\begin{array}{llllll}27 & 2.93 & .82 & 14 & 2.50 & .51\end{array}$

$\begin{array}{llllll}27 & 2.41 & 1.04 & 14 & 2.21 & .69\end{array}$ 


\section{Teachers' Responses}

In the Teacher questionnaire, teachers were asked nine questions pertaining to the use of technology in the learning and teaching environment (classroom).

Table D.2.2

Technology in the Learning and Teaching Environment: Teachers' Responses

FLN Schools Non FLN Schools

Item

$\begin{array}{llllll}\mathrm{n} & \mathrm{M} & \mathrm{SD} & \mathrm{n} & \mathrm{M} & \mathrm{SD}\end{array}$

The school provides adequate access to technology training for teachers.

$\begin{array}{lllll}76 & 3.17 & .79 & 73 & 2.84\end{array}$

.89

The school provides training to teachers on the integration of technology in the classroom.

$\begin{array}{llllll}75 & 2.79 & 1.00 & 72 & 2.69 & .91\end{array}$

The school provides school-wide technology staff development.

$\begin{array}{llllll}76 & 3.09 & .85 & 71 & 2.82 & .86\end{array}$

The school provides adequate technology equipment in the classroom.

$\begin{array}{llllll}77 & 3.23 & .68 & 72 & 3.06 & .76\end{array}$

The school provides adequate software in the classroom.

$\begin{array}{llllll}77 & 3.14 & .79 & 73 & 2.97 & .78\end{array}$

Teachers' use of technology to deliver instruction in the classroom.

$\begin{array}{llllll}67 & 2.13 & 1.05 & 61 & 1.89 & 1.05\end{array}$

Teachers' use of technology to promote collaborative learning in the classroom.

$\begin{array}{llllll}67 & 2.25 & 1.06 & 62 & 1.95 & .96\end{array}$

Teachers' use of technology to create authentic learning environment.

$\begin{array}{llllll}67 & 2.18 & .92 & 62 & 2.13 & 1.03\end{array}$

Teachers' use of technology to teach about technology.

$\begin{array}{llllll}62 & 1.89 & .87 & 58 & 2.00 & 1.06\end{array}$

The highest means for both groups were 3.23 and 3.06 and pertained to the "adequacy of technology equipment in the classroom". This finding suggests that 
teachers believe that they have adequate hardware. However, the lowest means were 1.89 and 2.00 and pertained to the teachers' use of technology to teach about it. This finding is consistent with findings from the previous sections suggesting that although the hardware infrastructure is available in schools, teachers are not provided with the necessary training to effectively use technology and integrate it into the teaching and learning in their classrooms. Also, the results suggest that teachers in both groups believe that technology should be used to enhance teaching and learning and not just to teach about it.

\section{Media Specialists' Responses}

In the Media Specialists' questionnaire, media specialists were asked nine questions pertaining to the use of technology in the Teaching and Learning environment. The highest means for both groups were 3.19 and 3.02 and pertained to the "adequacy of technology training for teachers". This finding, contrary to previous findings, suggests that media specialists believe that teachers have adequate access to training in technology. This could be biased and may be explained because media specialists are expected to provide support and training to regular classroom teachers on the use of technology. The lowest means were pertained to the teachers' use of technology in the classroom. This finding, however, is consistent with findings from the previous sections suggesting that teachers are not using technology effectively and are not integrating it into teaching and learning in their classrooms. 
Table D.2.3

Use of Technology in Teaching and Learning: Media Specialists Responses.

FLN Schools Non-FLN Schools

Item

$\begin{array}{llllll}n & M & \text { SD } & \mathrm{n} & \mathrm{M} & \mathrm{SD}\end{array}$

The school provides adequate access to technology training for teachers.

$\begin{array}{llllll}67 & 3.19 & .76 & 42 & 3.02 & .86\end{array}$

The school provides training to teachers on the integration of technology in the classroom.

$\begin{array}{llllll}62 & 2.87 & .82 & 40 & 2.68 & .88\end{array}$

The school provides school-wide technology staff development.

$\begin{array}{llllll}65 & 3.12 & .82 & 42 & 2.86 & .87\end{array}$

The school provides adequate technology equipment in the classroom.

$\begin{array}{llllll}67 & 3.19 & .78 & 42 & 2.64 & .90\end{array}$

The school provides adequate software in the classroom.

$\begin{array}{llllll}68 & 3.06 & .73 & 43 & 2.77 & .86\end{array}$

Teachers' use of technology to deliver instruction in the classroom.

$\begin{array}{llllll}62 & 2.11 & .96 & 37 & 1.84 & 1.04\end{array}$

Teachers' use of technology to promote collaborative learning in the classroom.

$\begin{array}{llllll}61 & 2.11 & .96 & 36 & 1.78 & .95\end{array}$

Teachers' use of technology to create authentic learning environment.

$\begin{array}{llllll}62 & 2.00 & .95 & 34 & 2.00 & 1.07\end{array}$

Teachers' use of technology to teach about technology.

$\begin{array}{llllll}60 & 1.93 & 1.03 & 37 & 1.68 & .94\end{array}$




\section{Use of Technology in Assessment and Evaluation}

Subsidiary Research Question 3: What was the difference in the use of Technology in the Assessment and Evaluation of students' learning between schools whose principals participated in the FloridaLeaders.net and those who did not participate?

The purpose of this question is to assess the degree to which the school ensures that curricular design, and instructional strategies integrate appropriate technologies to maximize learning and teaching.

Principals were asked four questions pertaining to the use of technology in the Assessment and Evaluation of students' learning. In the Teachers and Media Specialists questionnaire, participants were asked three questions about the use of technology in the Assessment and Evaluation of students' learning at their schools. It should be noted that all participants were asked questions to assess their own use and attitudes toward technology (self and peer-reporting) and also were asked to assess others. For example, principals were asked to rate their own use of technology in a specific area, and were also asked to rate their teachers' use of technology in this area. On the other hand, teachers were asked to rate their own use of technology, and also were asked to rate their principals' use of technology in that same area.

\section{Principals' Responses}

In the Principal questionnaire, principals were asked four questions pertaining to the use of technology in the Assessment and Evaluation of students' learning. Again, the principals were asked to rate their own use of technology in this specific area, and were also asked to rate their teachers' use of technology in the same area. 
Descriptive analyses of these items are listed in Table A.13. The results in this table revealed principals, in both groups, believe that teachers are in great need for technology professional development $(M=3.22$, and $M=3.15)$.

Table D.3.1

Use of Technology in Assessment and Evaluation: Principals' Responses.

Item

\begin{tabular}{cccccc}
\multicolumn{2}{c}{ FLN Principals } & \multicolumn{3}{c}{$\begin{array}{l}\text { Non-FLN } \\
\text { Principals }\end{array}$} \\
\hline$n$ & $M$ & SD & n & M & SD \\
\hline
\end{tabular}

The school assesses teachers' use of $\begin{array}{llllll}24 & 2.46 & 1.10 & 14 & 2.50 & 1.22\end{array}$ technology in their classroom.

The school assesses teachers' knowledge growth in technology.

$\begin{array}{llllll}24 & 2.21 & .97 & 14 & 2.43 & 1.01\end{array}$

Teachers' use of technology for assessment and analysis of students' data.

$\begin{array}{llllll}27 & 2.67 & 1.03 & 14 & 2.57 & .93\end{array}$

Teachers' needs for specific professional development in technology.

$\begin{array}{llllll}27 & 3.22 & .84 & 13 & 3.15 & 1.06\end{array}$

\section{Teachers' Responses}

In the Teacher questionnaire, teachers were asked three questions pertaining to the use of technology in the assessment and evaluation of students' learning. The results of the analysis indicated that there was a statistically significant difference between the two groups on the use of technology for assessment and evaluation. This finding suggests that teachers whose principals participated in the FLN project used significantly more technology to assess and evaluate their students' learning. This finding requires further 
investigation on "why the emphasis on assessment and evaluation of students' learning?" Is there a relationship to the general pressure that teachers are going through in terms of accountability and students performance? Are the Florida assessment system, especially the FCAT (Florida Comprehensive Assessment Test) and the Federal AYP (Annual Yearly Progress) legislations contributing to this?

Table D.3.2

Use of Technology in Assessment and Evaluation: Teachers' Responses.

\begin{tabular}{|c|c|c|c|c|c|c|}
\hline \multirow{2}{*}{ Item } & \multicolumn{3}{|c|}{ FLN schools } & \multicolumn{3}{|c|}{ Non-FLN schools } \\
\hline & $\mathrm{n}$ & M & $\mathrm{SD}$ & $\mathrm{n}$ & M & $\mathrm{SD}$ \\
\hline $\begin{array}{l}\text { The principal monitors teachers' } \\
\text { competency in technology. }\end{array}$ & 71 & 2.92 & .95 & 67 & 2.40 & .79 \\
\hline $\begin{array}{l}\text { The teachers need to gain knowledge in } \\
\text { technology. }\end{array}$ & 67 & 3.03 & .81 & 67 & 2.82 & .85 \\
\hline $\begin{array}{l}\text { The teachers use of technology to collect, } \\
\text { analyze, and interpret student data. }\end{array}$ & 65 & 2.71 & 1.12 & 63 & 2.52 & 1.13 \\
\hline
\end{tabular}

\section{Media Specialists' Responses}

In the Media Specialists questionnaire, media specialists were asked three items pertaining to the use of technology in the assessment and evaluation of students' learning.

Descriptive analyses are listed in Table D.3.2. A quick look at the results in this table reveals that the media specialists' average responses to the three items were comparable between media specialists whose principals participated in the FLN project and media specialists whose principals did not participate in the FLN project. 
It should be noted that the highest rated item for both groups pertained to the fact that "... The principals encourage teachers to gain knowledge in technology". This finding is contrary to the teachers' assessment, but consistent with the media specialist response to other items. As mentioned earlier, this could be biased and may be explained because media specialists are expected to provide support and training to regular classroom teachers on the use of technology.

Table D.3.3

Use of Technology in Assessment and Evaluation: Media specialists' Responses

\begin{tabular}{|c|c|c|c|c|c|c|}
\hline \multirow{2}{*}{ Item } & \multicolumn{3}{|c|}{ FLN schools } & \multicolumn{3}{|c|}{ Non FLN schools } \\
\hline & $\mathrm{N}$ & $M$ & SD & $\mathrm{n}$ & $\bar{M}$ & $\mathrm{SD}$ \\
\hline $\begin{array}{l}\text { The principal monitors teachers' } \\
\text { competency in technology. }\end{array}$ & 64 & 2.75 & .83 & 38 & 2.61 & .82 \\
\hline $\begin{array}{l}\text { The principal supports teachers need to } \\
\text { gain knowledge in technology and } \\
\text { encourages them. }\end{array}$ & 63 & 3.06 & .78 & 38 & 2.89 & .83 \\
\hline $\begin{array}{l}\text { The teachers' use of technology to collect, } \\
\text { analyze, and interpret student data. }\end{array}$ & 65 & 2.80 & 1.07 & 34 & 2.82 & 1.08 \\
\hline
\end{tabular}




\section{APPENDIX E}

Policy Implications

The dynamic of decision-making: Are decisions made based on hard evidence and data or politics?: The Example of Enhancing Technology Through Technology Federal Program 


\section{President Bush proposes to completely cut funding for the largest technology program: Enhancing Education Through Technology}

In February 2005, President Bush's 2006 budget request, called for $\$ 1$ billion less for the U.S. Department of Education --including elimination of the $\$ 500$ million Enhancing Education Through Technology (EETT) block-grant program, intended to bolster technology use in the nation's schools.

\section{Educational Technology advocates launch a nationwide campaign to restore} funding for the Enhancing Education Through Technology program

In March 2005, the State Educational Technology Directors Association (SETDA) released a report indicating that meeting the goals of the No Child Left Behind Act (NCLB) will become increasingly difficult should lawmakers agree to cut federal edtech spending in line with the president's plan. The report examined how EETT funding is being used in 49 states and the District of Columbia to help achieve the promise of NCLB. Its findings reflect 99 percent of the federal dollars allocated nationwide for educational technology in 2003-04. The report provided overwhelming evidence of the critical role that educational technology is playing in improving student achievement, providing professional development to ensure the recruitment and retention of highly qualified teachers, and using data to allow states and districts improved accountability.

On the other hand, on March 10, 2005, Education Secretary Margaret Spellings went before members of the House appropriations subcommittee to lobby for the president's $\$ 56$ billion education budget. The Bush administration says its funding plan for schools focuses on doing away with substandard initiatives in favor of programs that 
work. "Given the fiscal realities, we must target our resources wisely--toward flexibility and results, "Spellings told lawmakers in defense of the proposed cuts.

But the argument has done little to sway ed-tech advocates, many of whom have made the case for EETT by contacting their members of Congress. For example, the Ed Tech Action Network, a joint venture sponsored by the International Society for Technology in Education (ISTE) and the Consortium for School Networking (CoSN), have sent more than 4,000 faxes and email messages to members of Congress supporting the restoration of EETT funding. Technology advocates emphasized that our world is increasingly dependent on all forms of technology and that reductions in funding will prevent educators from preparing children for their future and for the future of this country.

\section{Lawmakers introduced bill to the US Senate to restore funding for the federal} Enhancing Education Through Technology, April 7, 2005

The bill measure requested Congress and the President to fully restore federal Enhancing Education Through Technology Act funding to the amount originally authorized under the federal No Child Left Behind Act of 2001.

The Bill highlighted and presented the following arguments (http://www.cde.ca.gov, Retrieved July 15,2005$)$ :

- School districts receiving funds from federal Enhancing Education Through Technology (EETT) Act grants utilize those funds to close the achievement gap, enhance data systems to support accountability, and provide the training necessary for teachers to become highly qualified users of technology, in order to support student learning; 
- Federal EETT Act funds are the primary source of technology funds for school districts;

- Professional development for teachers to effectively use technology and high-speed networks is well-documented and the need for that training is addressed with federal EETT Act funding;

- Evaluations show that federal EETT Act funding resulted in measurable improvements in teaching practice and student learning;

- Federal EETT Act funding has increased access to, and the effective use of, technology by rural and underserved students; and

- Federal EETT Act projects have consistently and significantly expanded and enriched learning opportunities for students.

The Bill then recommended that Congress and the President to fully restore federal Enhancing Education Through Technology Act funding to the amount originally authorized under the federal No Child Left Behind Act of 2001.

\section{US Senate restored funding for the federal Enhancing Education through}

\section{Technology, July 13, 2005}

Educational technology leaders celebrated a Senate subcommittee decision to provide $\$ 425$ million in funding for the Enhancing Education Through Technology (EETT) federal block-grant program for the school year 2005-2006.

The decision gives ed-tech advocates a reason to cheer. In February 2005, the Bush administration eliminated EETT as part of its 2006 budget proposal. Keith Krueger, chief executive officer of the Consortium for School Networking (CoSN), a national 
nonprofit organization that helps schools integrate technology, indicated that the Senate subcommittee action to restore EETT funding, came as result of tenacious work that the members of the consortium did to convince Congress that EETT must be fully funded.

The Senate action was significant, because EETT is the largest single source of federal funding for instructional technologies such as computers, software, projectors, training, and support (http://www.cosn.org, Retrieved July 15, 2005). 
APPENDIX F

VITA 


\section{Education}

\section{TAREK CHEBBI}

Doctoral Candidate in Education

2005

Florida International University

Miami, Florida

Graduate work in computer science at:

1985-1987

George Washington University, Washington, DC.

University of Massachusetts, Amherst, MA.

Graduate Center of the City University of New York, NY.

1984

Masters in Computer Science and Management (with honors), University of Tunis: School of Science and Mathematics.

1980

Diploma of Higher studies in Quantitative Methods, University of Sfax: School of Economic Sciences and Management.

\section{Professional Experience}

2003-Present

Director: Accountability and System-wide Performance, Miami-Dade County Public Schools (M-DCPS)

2001- 2003

Faculty/Staff: College of Education, Florida International University.

$1997-2001$

Director, Miami-Dade Area Center for Educational Enhancement, Office of Educational Planning, M-DCPS

1992- 1997

Evaluator and Coordinator, Office of Educational Research and Evaluation, M-DCPS.

$1988-1991$

1986-1987

Information Systems Manager at the United States Agency for International Development, Tunisia

Software Engineer, Solutions Engineering Inc. Amherst Massachusetts

Research Assistant at the Institut National de Recherches en Informatique et en Automatique (INRIA) Paris, France. 
Published, "What Makes It Go? A Look at the Design and Implementation of an Interdisciplinary mathematics and Science Workshop for In-service and Pre-service Elementary Teachers". A Journal on the Art of Teaching, April, 2002.

Presented the "School Improvement Plan Companion" software to the American Educational Research Association. Received the 1997 Annual Award, Division H.

Presented the "School Improvement Plan Companion" software at the annual meeting of the Florida Educational Research Association, November 1996.

Presenter: Seminar on Languages and linguistics, Stanford University, 1987.

Organizer: Panel on "Use of Computers in Linguistic Research", Georgetown University Round Table on Languages and Linguistics, Washington DC 1986. 